\title{
Temporal Variability and Vertical Structure in Larval Abundance: The Potential Roles of Biological and Physical Processes
}

\author{
by \\ Elizabeth D. Garland \\ B.S., Florida Institute of Technology, 1985 \\ Submitted in Partial Fulfillment of the Requirements for the Dual Degrees of \\ DOCTOR OF PHILOSOPHY

\begin{abstract}
at the
MASSACHUSETTS INSTITUTE OF TECHNOLOGY

and the

WOODS HOLE OCEANOGRAPHIC INSTITUTION
\end{abstract}

February 2000

(C) 2000 Elizabeth D. Garland

All rights reserved

The author hereby grants to MIT and WHOI permission to reproduce paper and electronic copies of this thesis in whole or in part and to distribute them publicly

Signature of Author

XointProgram in Biological Oceanography Massachusetts Institute of Technology and

Woods Hole Oceanographic Institution

October 22, 1999

Certified by

Cheryl Ann Butman

Senior Scientist, Applied Ocean Physics and Engineering Department

Woods Hole Oceanographic Institution

Thesis Supervisor

Accepted by

Mark E. Hahn

Chair, Joint Committee for Biological Oceanography

Woods Hole Oceanographic Institution 
This dissertation is dedicated to Tasha

for reminding me to live each day purposefully 


\title{
Temporal Variability and Vertical Structure in Larval Abundance: The Potential Roles of Biological and Physical Processes
}

\author{
by
}

\begin{abstract}
Elizabeth D. Garland
Submitted to the Massachusetts Institute of Technology - Woods Hole Oceanographic Institution Joint Program in Biological Oceanography on October 22, 1999 in Partial Fulfillment of the Requirements for the Degree of Doctor of Philosophy
\end{abstract}

\begin{abstract}
Recruitment variability in benthic invertebrate populations results from variability in planktonic larval supply and from processes occurring during and after larval settlement onto the seafloor. The focus of this thesis is on the temporal and spatial variability in larval supply, the extent to which planktonic larval distributions are determined by larval behaviors and physical processes, and how differentially distributed larvae are advected to potential adult habitats by inner-shelf circulation such as wind-driven upwelling and downwelling. This research capitalized on two sets of larval concentration time series, collected by moored zooplankton pumps, and complemented by synoptic hydrographic time-series data.
\end{abstract}

High variability was observed in larval concentration time series, yet the variations were nonrandom. Within the context of the sampling regime, two dominant modes of variability existed. One source of variation was associated with the synoptic meteorological time scale, and the other with the diurnal time scale. Over relatively long time scales, larvae were associated with particular water masses, defined by temperature-salinity characteristics. Within a particular water mass, group-specific vertical patterns were observed over both long and short time scales. "Lowfrequency" temporal variations resulted primarily from wind-driven cross-shelf transport of water masses in which larvae were differentially distributed relative to the thermocline. "Higherfrequency" variations were attributed to diel vertical migrations. These findings suggest that larvae were passive to the degree that they were horizontally advected with certain water masses, but active to the degree that they could alter their vertical position in the water column.

Local hydrodynamics, larval associations with specific water masses, and the vertical structure of larvae resulted in differential larval transport to potential adult habitats. Larval data indicate the times and places of possible coupling between water-column organisms and the benthos, leading to certain predictions regarding when and where larval settlement should be greatest.

Time-series measurements of larval concentration yield a new perspective on the temporal and spatial variability in larval distributions at an inner-shelf site. Determining how processes operating at the synoptic and diurnal time scales are coupled, and to what extent they influence recruitment variability, represents a challenging extension of this work.

Thesis Supervisor: Cheryl Ann Butman, Senior Scientist

Applied Ocean Physics and Engineering Department

Woods Hole Oceanographic Institution 


\section{ACKNOWLEDGEMENTS}

The six years behind this thesis have been filled with memorable interactions with scientists, family and friends. It is a pleasure to acknowledge their contributions to this work and to my life.

First of all, I thank my family and friends. My parents encouraged me to follow my dreams at an early age, and that encouragement has never waned over the years. My husband, Doug, has been a wonderful soul mate for over 13 years, and has been particularly patient with me and resourceful during the last few years. Though we haven't gotten in as much sailing and diving as we used to, we have managed to start a family, and that has brought us tremendous joy (and incredible sleep-deprivation). What would our lives be like without Tasha? Thanks to Wesley (or will it be Westly?) - due any day now - for refraining from bursting onto the scene at the public defense of my dissertation, or before this thesis was submitted. My friends have also been essential to my happiness through thick and thin!

To my advisor, Cheryl Ann, I owe a great deal of gratitude for sticking with me while I pursued other aspects of the research that she considered bland, but I thought was the hottest stuff in town at the time. Surprisingly, the final product is not far off from what I set out to study 6 years ago! Cheryl Ann has a diverse and truly impressive understanding of biological-physical interactions based on 20-plus years of observations made in the laboratory and in the field. I am fortunate to have had her as an advisor.

Thanks also to the other members of my committee (Steven J. Lentz, Heidi M. Nepf, Peter H. Wiebe, Scott M. Gallager, and Jesús G. Pineda) for the interesting, always very diverse, and often tangential discussions that have certainly kept me intellectually stimulated over the years and focused on the "bigger picture." Special thanks to Steve Lentz for his time and patience while I tried to make sense of the coupled biological and physical time-series data. Steve never gave me "the answer," but kept re-directing me (in a very polite way) toward more productive thoughts. Thanks to Heidi Sosik for chairing my defense and for offering a new perspective on life and science (and sometimes motherhood) at times when my perspective was narrowing.

Although Judy Grassle did not serve on my committee, she played a dominant role in shaping my thoughts over the years through conversations and her publications. Tom Capo was my first supervisor at WHOI and introduced me to larvae and the methods of working with them. Lauren Mullineaux was my second supervisor at WHOI and introduced me to biological-physical interactions involving larvae. I recall asking Lauren in the late 80 's what all the fuss was about "temporal and spatial scales of biological variability." I don't recall her exact answer, but I'm sure it fueled some of the ideas I pursued in my graduate research. Furthermore, she offered me opportunities at and below sea that will remain in my "good memories" slot forever. 
WHOI has an unbeatable support staff. Special thanks to Judy Kleindinst, Colleen Hurter and Heidi (at the MBL Library), Julia Westwater, Jayne Doucette, Bill Lange, Will Ostrom, Terry Rioux and many, many, many other engineers, marine personnel, staff assistants, and scientists who have offered assistance and conversation. I depended on a whole cast of characters for assistance with sample collection and analysis, and they are acknowledged in the individual chapters of this thesis.

This research was supported by grants from the National Science Foundation's Coastal Ocean Processes (CoOP) Program (OCE91-23514 and OCE92-21615 to Cheryl Ann Butman, and OCE96-33025 to Steven J. Lentz and Cheryl Ann Butman); the National Oceanic and Atmospheric Administration's National Sea Grant Program Office, Department of Commerce (Grant \# NA46RG0470, Woods Hole Oceanographic Institution Sea Grant Project No. RB-132 and RB-139 to Cheryl Ann Butman and Elizabeth D. Garland); and the WHOI Education Program. 


\section{TABLE OF CONTENTS}

Title Page

Page \#

Abstract

Acknowledgements

Table of Contents

7

List of Figures

List of Tables

Chapter One: General Introduction

$\begin{array}{ll}1.1 \text { Introduction and Rationale } & 14\end{array}$

1.2 Terminology 18

1.3 Background 21

1.3.1 Variations in Planktonic Larval Concentration Data 21

1.3.2 Physical Processes Influencing Larval Distributions and Transport $\quad 23$

1.3.3 Biological and Physical Processes Influencing Vertical Distributions 27

1.4 Objectives and Approach of Thesis Research 34

1.5 Description of the Coastal Ocean Processes Field Study ("CoOP94") 36

1.6 Literature Cited

Chapter Two: Planktonic Larval Concentrations in a Nearshore

Environment: Temporal Variability on Scales of Hours to Days

$2.1 \quad$ Introduction $\quad 59$

2.2 Methods 61

2.2.1 Study Location $\quad 61$

2.2.2 Sampling Techniques 62

2.2.3 Sample Processing and Analysis 64

2.3 Results 65

2.3.1 Oceanographic Setting at the Study Site 65

2.3.2 Patterns in Larval Concentration $\quad 70$

2.3.3 Scale of Temporal Variability 75

$\begin{array}{lll}2.4 & \text { Discussion and Conclusions } & 78\end{array}$

$\begin{array}{ll}2.5 & \text { Acknowledgements } \\ 2.6 & 87\end{array}$

2.6 Literature Cited $\quad 88$

Chapter Three: Vertical Structure in Larval Concentration at an 95

Inner-Shelf Site: The Roles of Physical Processes and Larval Behavior

$\begin{array}{lll}3.1 & \text { Introduction } & 97\end{array}$

3.2 Methods 101

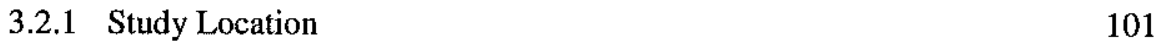

3.2.2 Sampling Techniques 102

3.2.3 Sample Processing • $\quad 104$

3.2.4 Analysis of Time Series 107 
3.3 Oceanographic Setting at the Study Site 110

3.4 Results 116

3.4.1 General Characteristics of Larval Concentration Time Series $\quad 116$

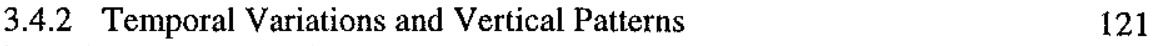

$\begin{array}{lll}3.5 & \text { Discussion and Conclusions } & 143\end{array}$

$\begin{array}{ll}3.6 & 160\end{array}$

$\begin{array}{lll}3.7 & \text { Literature Cited } & 161\end{array}$

$\begin{array}{ll}\text { Chapter Four: General Conclusions } & 171\end{array}$

$\begin{array}{lll}4.1 & \text { Introduction } & 172\end{array}$

4.2 Conclusions of the 1993 and 1994 Field Studies 172

4.3 Comparison Between the 1993 and 1994 Field Studies 176

4.4 Recommendations for Future Research $\quad 178$

$\begin{array}{lll}4.5 & \text { Literature Cited } & 182\end{array}$

Appendix A: Techniques for the Identification of Bivalve Larvae 183

$\begin{array}{lll}\text { A.1 Introduction } & 184\end{array}$

$\begin{array}{lll}\text { A.2 Morphological Techniques } & 187\end{array}$

$\begin{array}{lll}\text { A.3 Immunological Techniques } & 189\end{array}$

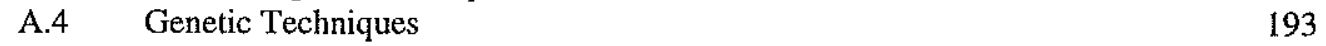

$\begin{array}{lll}\text { A.5 Automated Optical Techniques } & 195\end{array}$

$\begin{array}{llr}\text { A.6 Perspective } & 197\end{array}$

A.7 Acknowledgements $\quad 201$

$\begin{array}{lll}\text { A.8 } & \text { Literature Cited } & 202\end{array}$

$\begin{array}{ll}\text { Biographical Note } & 213\end{array}$ 


\section{LIST OF FIGURES}

Figure 1.1 Life cycle of a bivalve clam

Page \#

15

Figure 1.2 Stommel Diagram illustrating scales of biological and

17 physical variability

Figure 1.3 Map showing study region off Duck, North Carolina 24

Figure 1.4 Schematic illustrating CoOP94 Project's cross-shelf array 38 of moored instruments, August 1994

Figure 1.5 Diagram of the Moored, Automated, Serial, Zooplankton 40 Pump (MASZP)

Figure 2.1 Oceanographic setting at the Duck study site during July 1993

Figure 2.2 Oceanographic setting at the Duck study site during July $19-22,1993$

Figure 2.3 Time series of larval concentration, temperature and alongshore wind velocity, July 19-22, 1993

Figure 2.4 Cross-correlation between larval bivalve and barnacle cyprid concentrations

Figure 2.5 Cross-correlation between alongshore component of wind $\quad 74$ velocity and larval bivalve concentration

Figure 2.6 Autocorrelation functions for larval bivalve and polychaete concentrations

Figure 2.7 Hypothesized mechanism for generating observed variations in larval concentration

Figure 3.1 Moored plankton pumps and physical sensors at the 20-m site, 103 August 1994

Figure 3.2 Time series of water temperature as a function of depth, and wind velocity at the 20-m site, August 1994 
Figure 3.3 Response to meteorological forcing of water temperature, salinity, cross-shelf currents, and near-bottom conditions.

Figure 3.4 Time series of larval concentration for polychaete larvae

Figure 3.5 Time series of larval concentration for bivalve larvae

Figure 3.6 Time series of larval concentration for gastropod larvae

Figure 3.7 Time series of larval concentration for brachyuran crab zoea

Figure 3.8 Temperature-Salinity Diagram for the 20-m site, August 1994

Figure 3.9 Temperature-Salinity-Plankton (T-S-P) plot for polychaete larvae day/night cycle

Figure 3.11 Autocorrelation function for polychaete larvae

Figure 3.12 Temperature-Salinity-Plankton (T-S-P) plot for bivalve larvae

Figure 3.13 Time series of larval concentration showing increased taxonomic resolution for bivalve larvae, middle pump

Figure 3.14 Temperature-Salinity-Plankton (T-S-P) plot for gastropod larvae

Figure 3.15 Temperature-Salinity-Plankton (T-S-P) plot for brachyuran crab zoea 


\section{LIST OF TABLES}

Table 2.1 Summary statistics of larval concentration time-series data

Page \#

77

Table $3.1 \quad$ Summary statistics of larval concentration and physical

115 time-series data

Table 3.2 Decorrelation times for larval concentration and physical

122

time-series data 


\section{CHAPTER 1}

General Introduction 


\subsection{INTRODUCTION AND RATIONALE:}

Evidence from a wide variety of coastal and deep-sea habitats indicates that many species of invertebrate larvae (Fig 1.1) are not supplied to benthic habitats continuously as once purported (Hensen, as cited in Haeckel 1883; Coleman 1933). Instead, larvae arrive at the bottom in discrete pulses (e.g., Gaines et al. 1985; Farrell et al. 1991; Roughgarden et al. 1987 and 1991; Pineda 1991; Wing et al. 1995a; Mullineaux et al. 1995). Variability in the timing, spacing and intensity of larval pulses will be translated into recruitment variability as long as the planktonic larvae are competent to metamorphose and settle into the adult habitat. Thus, the spatial and temporal dynamics of larval distributions while in the water column may account for much of the unexplained variability in population distributions and dynamics of benthic adults (e.g., Thorson 1950; Connell 1985; Butman 1987; Roughgarden et al. 1987, 1988; Underwood and Fairweather 1989; Minchinton and Scheibling 1991). The complexity of the problem, however, has rendered larval biologists both intellectually intrigued and challenged for over a century (reviewed in Scheltema 1986; Boicourt 1988; Young 1990).

Spatial and temporal variability in larval distributions is controlled by a wide range of oceanographic processes interacting with the life histories and behaviors characteristic of species and ontogenetic stages (see section 1.3). Furthermore, physical, biological, geological and chemical processes influence larval distributions to varying degrees along a spectrum of time and space scales (Fig. 1.2; e.g., Haury et al. 1978; reviews by Young and Chia 1987; Boicourt 1988; Dickey 1990; Taggart and Frank 1990; Kingsford 1990; Bakun 1996). 


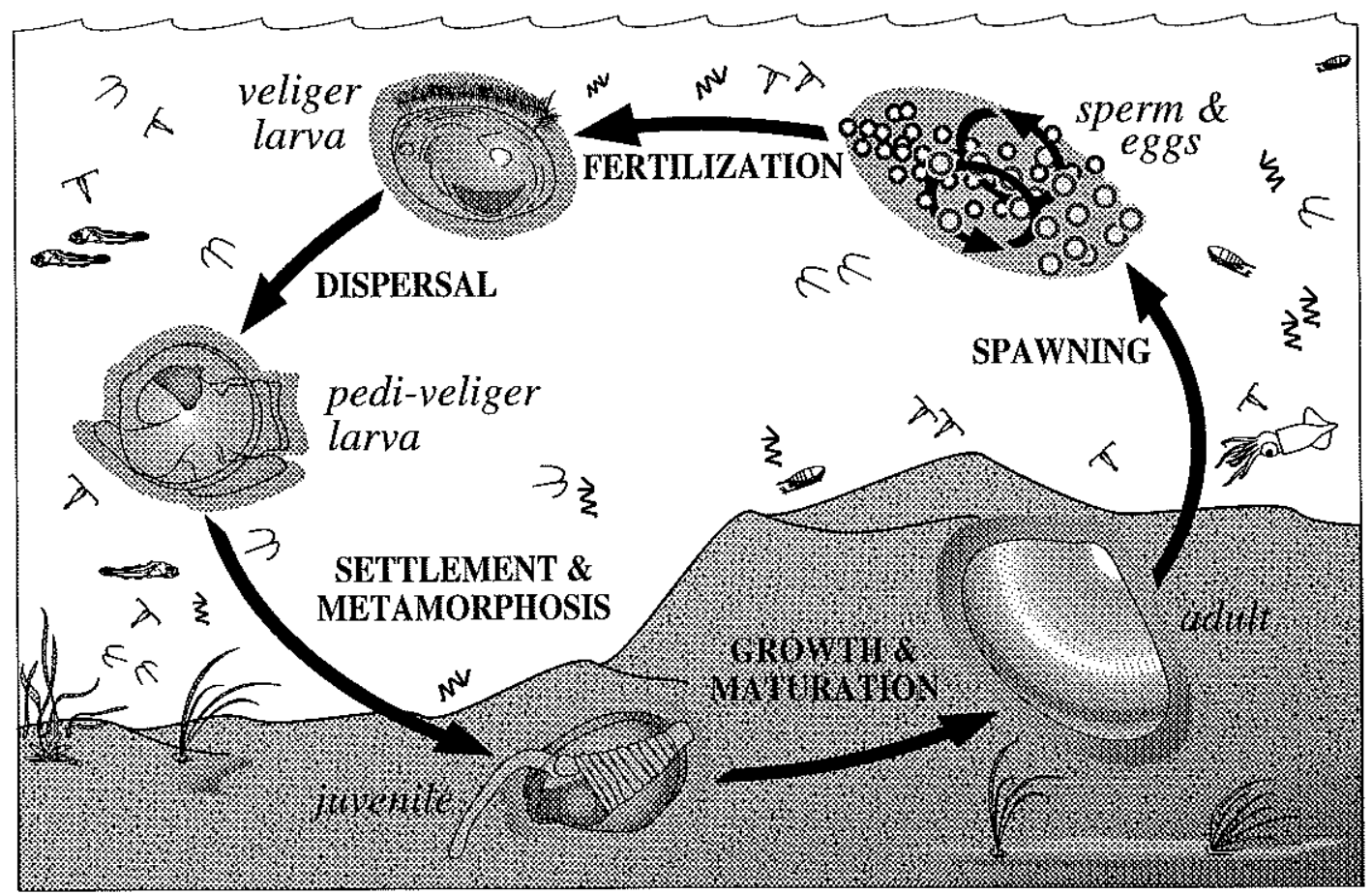

Figure 1.1 A schematic showing the life cycle of a bivalve clam. Adults release eggs and sperm into the water column where fertilization takes place. Larvae develop in the plankton for several weeks before settling back down to the sea floor, metamorphosing into sessile adults, and recruiting into benthic communities. While in the water column, larvae are susceptible to numerous biological, chemical and physical processes. In temperate latitudes, many species of benthic invertebrates possess a planktonic larval stage that disperses for hours to months before returning to a suitable adult habitat. 
Fine- $(1 \mathrm{~m}$ to $1 \mathrm{~km})$ to meso- (100 to $1000 \mathrm{~km}$ ) scale (as defined by Haury et al. 1978) physical processes that occur on shorter (hours to several weeks) time-scales, such as wind-driven upwelling and downwelling, fronts, eddies, tides, internal waves, tidal bores, waves and storms, will likely have the most significant impact on larvae that disperse in the water column for several weeks to several months (e.g., Boicourt 1988; Pineda 1991; Shanks 1995). In addition, biological factors such as vertical migratory behaviors tuned to the diel light/dark cycle, presence or absence of food and predators, spawning events, growth, and natural mortality can occur simultaneously with physical processes and contribute to heterogeneity in larval distributions on similar scales (Tremblay and Sinclair 1990b; Rumrill 1990; Morgan 1995b).

The primary goals of this thesis research were to evaluate to what extent planktonic distributions of invertebrate larvae are determined by larval behaviors and physical processes, and to examine how differentially distributed larvae are advected to potential adult habitats by inner-shelf circulation such as wind-driven upwelling and downwelling. Addressing the goals of this research involved identifying the time-scales of variability in larval concentration, the vertical patterns of larval distributions, and the most likely mechanisms for patterns of larval distributions (see section 1.3).

Recruitment into benthic communities is affected by the intensity and timing of larval delivery to the substrate, the amount of suitable substrate, and by post-settlement processes such as competition and predation (e.g., Connell 1985; Gaines and Roughgarden 1985; Peterson 1986). Thus, an understanding of the time-scales of 


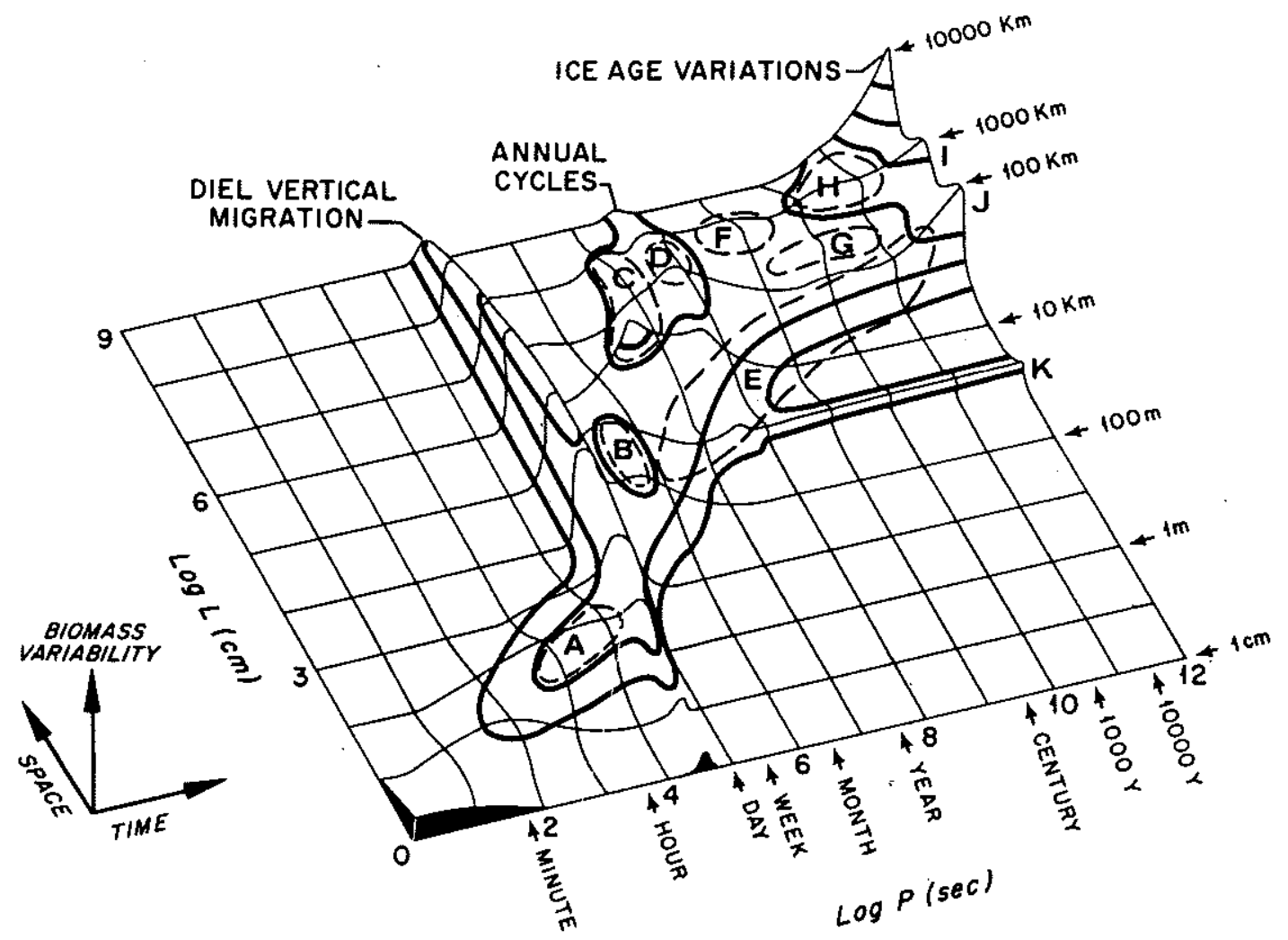

Figure 1.2 A conceptual model of the time-space scales of variations in zooplankton biomass, and the factors contributing to them. A: 'micro' patches. B: swarms. C: upwelling. D: eddies and rings. E: island effects. F: El-Nino-type events. G: small ocean basins. H: biogeographic provinces. I: currents and oceanic fronts - length. J: currents - width. K: oceanic fronts - width. Adapted from Haury et al. 1978. 
variability in larval concentration is required for elucidating the coupling between larval availability and recruitment into benthic populations, and offers insights into possible biological-physical interactions. Identifying the mechanisms responsible for generating the observed patterns in larval distributions augments the ability to predict, and possibly, control when and where recruitment will be maximal.

This introductory chapter defines the terminology used throughout this thesis (section 1.2), then briefly discusses variations in larval abundance data (section 1.3.1), the physical processes that can lead to differential transport of planktonic larvae over the inner shelf (section 1.3.2), and the biological and physical processes that can determine the vertical distribution of larvae (section 1.3.3). Samples of planktonic invertebrate larvae require an exorbitant amount of processing time, mainly due to difficulties associated with identification of larvae. To highlight some of the problems often encountered in processing larval samples, a brief overview is given on techniques for the identification of bivalve larvae (Appendix A). Specific research questions addressed in this thesis as well, as the approach, are outlined in section 1.4. Finally, there is a brief description of the much larger interdisciplinary field study of which this thesis research was a small part (section 1.5).

\subsection{TERMINOLOGY}

Throughout this thesis, the following terminology had been adopted: 
Fine-scale: Processes occurring over spatial scales of $1 \mathrm{~m}$ to $100 \mathrm{~m}$ (as defined by Haury et al. 1978), such as individual-individual interactions.

Coarse-scale: Processes occurring over spatial scales of 1 to $100 \mathrm{~km}$ (as defined by Haury et al. 1978), such as fronts and diel vertical migrations.

Meso-scale: Processes occurring over spatial scales of 100 to $1000 \mathrm{~km}$ (as defined by Haury et al. 1978), such as eddies, currents and upwelling.

Patch: a cluster of larvae occurring in higher concentrations relative to a lower background concentration. In this definition, the clustering of larvae into a patch can result from either biological behaviors (e.g., spawning synchronicity or aggregating behaviors) or physical processes. (See García-Moliner et al. 1993). Aggregation: a special case of larval patches that are formed exclusively by interactions among individual larvae.

Passive Larval Transport: considers larvae to be non-swimming and largely at the mercy of physical processes (e.g., advection and settling due to the forces of gravity). Larvae are not necessarily conservative tracers of the flow (unless they are neutrally buoyant); instead they track like negatively buoyant sediment particles in a given flow field.

Active Larval Behaviors: considers larvae to exhibit swimming behaviors that can alter their vertical or horizontal position. 
Diurnal: a time scale used to characterize processes with periods close to $24 \mathrm{hr}$ (also known as the "diurnal band"). In this definition, the processes (e.g., diurnal tides) need not be tied to the day/night cycle. This is in contrast to the way many biological studies define "diurnal" as referring to processes that occur during the day time (e.g., diurnal migration). Since this research involves coupling both biological and physical processes, the former definition, with no ties to the day/night cycle, has been adopted to reduce potential ambiguity.

Diel: a time scale used to characterize processes with periods of $24 \mathrm{hr}$ that are tied to the day/night cycle (e.g., diel vertical migration).

Nocturnal: occurring at night

Dispersal: movement of larvae due to diffusion and advection.

Metamorphic Competency: a developmental stage signaling the likely onset of metamorphosis - from larval forms into the adult body plan — once a larva has settled onto the seafloor.

Settlement: the period during which larvae reach the sea floor and may react to biological, physical and chemical cues prior to metamorphosing and remaining on the bottom as a sessile juvenile.

Recruitment: the addition of organisms into an existing adult population. Recruitment is influenced by pre-settlement (e.g., larval supply), settlement (e.g., finding and responding to the right cues necessary for metamorphosis), and post-settlement processes (e.g., competition). 


\subsection{BACKGROUND}

\subsubsection{Variations in Planktonic Larval Concentration Data}

The planktonic habitat is three-dimensional, highly advective, and, as a consequence, markedly variable. Water-column processes operating over nine orders of magnitude of time and space scales - from molecular diffusion $(<$ few mm and $<1 \mathrm{sec}$; Mann and Lazier 1991) or turbulent mixing (few mm - few m and $1 \mathrm{sec}-10$ 's of min; Mann and Lazier 1991) to internal waves ( $1 \mathrm{~min}$ to the inertial frequency and $10 \mathrm{~m}$ to $1 \mathrm{~km}$ ) to great gyre circulations (up to ten years and on basin scales) - contribute to variability in distributions of planktonic organisms (Fig. 1.2; Haury et al. 1978; Legendre and Demers 1984; Boicourt 1988; Rothschild 1988; Dickey 1990; Powell 1989; Mann and Lazier 1991). Spatial and temporal variations interact in complex ways, especially when biological processes, such as species-specific larval behaviors in response to environmental cues, are superimposed on the physical processes responsible for shaping passive larval distributions. When physical processes dominate an oceanographic system, the relationship between time and space is log-linear (Stommel 1963); biological processes, however, cause the relationship to depart from linearity (Haury et al. 1978). For coupled physical and biological systems, Haury et al. (1978) suggested that greater insights may be gained by considering temporal variability separately from spatial variability to reduce the dimensionality of the problem.

Within a patch of larvae, temporal fluctuations in larval abundance result primarily from biological processes (Mackas et al. 1985; Young and Chia 1987), such as seasonality and synchrony of larval release (Morgan 1995a), length of the planktonic 
period (Jørgensen 1981), differential mortality due to starvation or predation (Rumrill 1990), and larval swimming behaviors (Pennington and Emlet 1986; Scrope-Howe and Jones, 1986). Spatial fluctuations of larval abundance within a patch of larvae are primarily due to a combination of physical and biological processes that interact to create, maintain or destroy patches of larvae. Horizontal movement of patches is primarily due to lateral advection because horizontal swimming speeds of most invertebrate larvae (except for large decapod larvae) are negligible compared to typical current speeds above the bottom boundary layer (Mileikovsky 1973; Chia et al. 1984). Vertical movement of larval patches can result from active movements of larvae, turbulent mixing, or advection of water masses containing larvae. There may also be a strong depth- and larval age- or stage-dependence to these processes.

Separating contributions from temporal, horizontal and vertical processes depends on whether the reference frame is Eulerian or Lagrangian. Using Eulerian techniques, spatial patterns will be recorded as temporal fluctuations as water masses are advected past the fixed sampler. Local events, such as near-bottom spawning or resuspension, can also generate temporal variations in the data series. The role of advection can be evaluated by deploying simultaneously a three-dimensional spatial array of moored timeseries larval collectors and physical sensors. 


\subsubsection{Physical Processes Influencing the Larval Distributions and Transport}

Fine- to meso-scale and short (hours to several weeks) time-scale physical processes, such as rings and eddies, fronts, plumes, tides, internal waves, and wind-driven events (e.g., upwelling and downwelling, storms and waves), will likely have the most significant impact on larvae that disperse in the water column for several weeks to several months (e.g., Boicourt 1988; Pineda 1991; Shanks 1995). Of these physical processes, wind-driven upwelling and downwelling, tidally driven processes, and riverine discharge plumes are the most common on the inner-shelf where the present study was conducted (Fig. 1.3).

Wind-Driven Phenomena: Wind stress causes water to flow, waves to form, and Langmuir cells to develop. The dominant influence of wind events is manifest at four characteristic scales: the diurnal land-breeze/sea-breeze cycle, the synoptic meteorological time scale of approximately $2-7$ days, episodic storm events, and a seasonal component. Wind-driven processes occurring at these scales can alter the magnitude and direction of currents up to hundreds of meters below the surface, which can lead to concurrent changes in larval distributions (e.g., Taggart and Leggett 1987; Goodrich et al. 1989; Hobbs et al. 1992).

Winds blowing toward the north/northeast on the east coast and toward the south on the west coast of North America initiate upwelling, where water is advected offshore at the surface (i.e., to the right of the wind direction) and balanced by a shoreward 


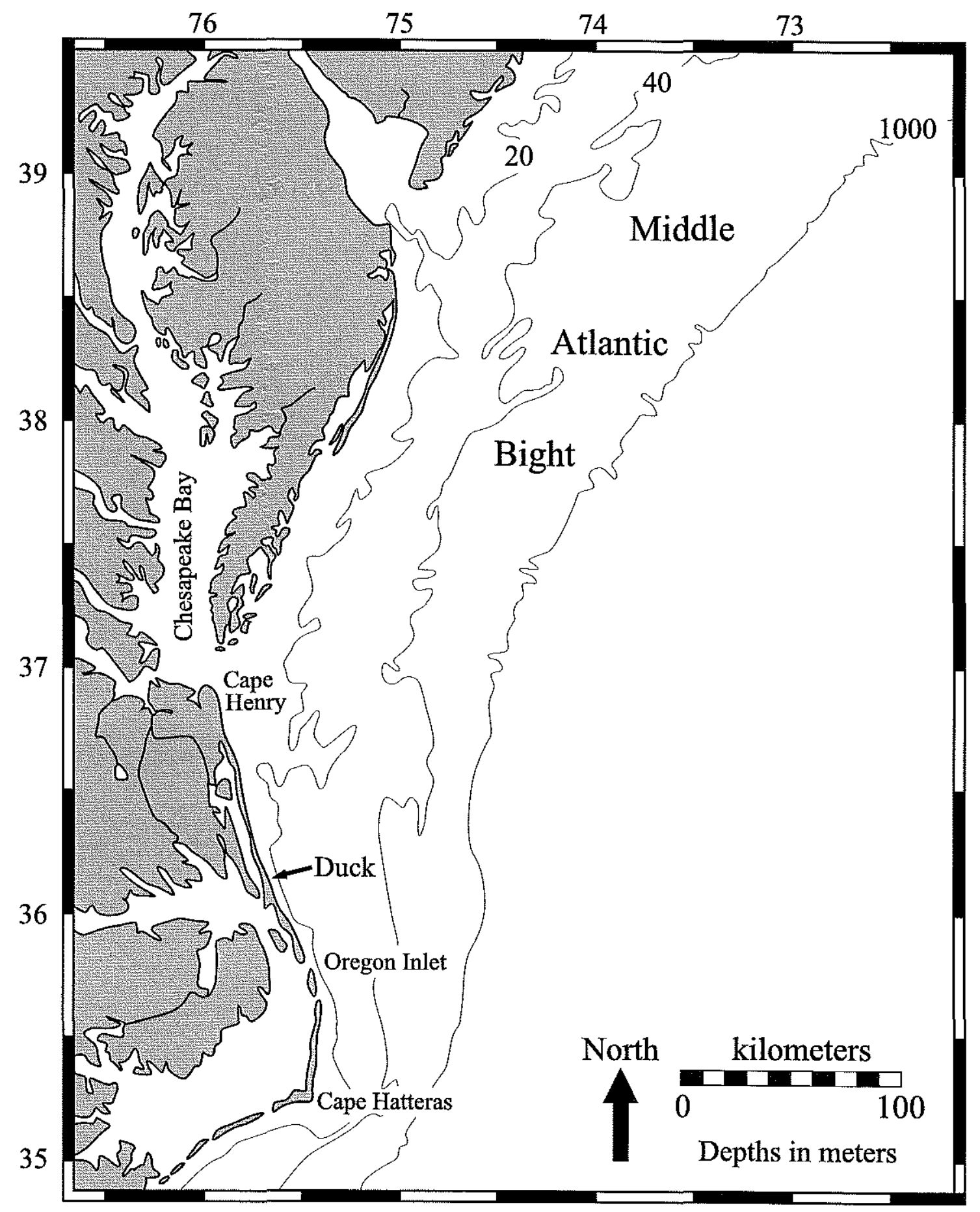

Figure 1.3 Map showing location of study region off Duck, NC, USA. 
movement of bottom waters upwelling at the coastal boundary (Ekman 1905; Smith 1968; Barber and Smith 1981; Richards 1981). If the water column is thermally stratified, isotherms become up-turned at the coast. When the winds diminish or change direction, relaxation of upwelling occurs at the coast and isotherms become nearly horizontal. Alternatively, in the presence of strong winds blowing toward the south/southwest on the east coast or north on the west coast, downwelling occurs, and the downwelled thermocline is advected offshore. During periods of wind-driven, crossshelf circulation (i.e., upwelling and downwelling), the water column develops into a two-layer system where the surface and bottom layers are flowing in opposite directions. Horizontal direction of larval transport by these currents would depend on the vertical position of larvae in the water column (e.g., Bowden 1965; Okubo 1967; Kullenberg 1972 and 1978; see section 1.3.3). For example, planktonic larvae occurring below the thermocline during upwelling events and those in surface waters during downwelling events will eventually contact the bottom or the shoreline, respectively. In fact, settlement and recruitment events along the west coast of North America have been attributed to the periodic relaxation of upwelling conditions (e.g., Farrell et al. 1991; Roughgarden et al. 1991; Wing et al. 1995a and 1995b; Miller and Emlet 1997; Grantham 1997; Shkedy and Roughgarden 1997; Connolly and Roughgarden 1999).

Riverine or Estuarine Plumes: Salinity fronts emanating from riverine or estuarine discharge areas also influence larval abundance, distributions, and transport (e.g., Le Févre 1986; Garvine 1986; Mann 1988). These buoyancy currents often transport larvae 
in different directions than inner-shelf currents. For example, estuarine species in the plume may be advected to distant inner-shelf habitats that are not optimal for adult survival or reproduction (Boicourt 1982; Boicourt et al. 1987; Epifanio 1988; Pietrafesa and Janowitz 1988). The transport of these species back to estuarine habitats appears to result from both larval behaviors and cross-shelf flows (e.g., Johnson 1985; Boehlert and Mundy 1988). In addition, lower-salinity plumes that hug the coastlines during downwelling conditions could serve as a barrier to cross-shelf dispersal of inner-shelf species.

Tides and Related Phenomena: Tidal flows can move larvae passively by resuspending them in peak tidal velocities (e.g., Levin 1986; modeled by Gross et al. 1992). Alternatively, larvae could respond to some cue associated with the semi-diurnal tide by altering their swimming behavior (see section 1.3.3). In addition, other physical processes associated with the tidal cycle, such as internal waves and tides, have been implicated in the cross-shelf transport of larvae (e.g., Shanks and Wright 1987; Pineda 1991; Shanks 1995), and were prevalent at the study site (S.J. Lentz, pers. comm.). Typically at the continental shelf break there is an abrupt change in bottom slope. As the tide ebbs over the shelf break, a wave can be generated along the pycnocline as it suddenly deflects in response to the abrupt drop-off in bottom topography. Subsequently, the waves can be propagated shoreward on a flooding tide. Internal tidal bores form when internal tidal waves propagating to shore encounter shallower depths; the wave amplitudes steepen in response to shoaling depths and can eventually break. The time 
scales associated with these features have periods less than or equal to the to semidiurnal range (Garrett and Munk 1972 and 1975; Chereskin 1983; Pond and Pickard 1983) or multiples of that frequency that are especially pronounced on spring-neap tidal periods (Pineda 1995).

Surface slicks can form when positively buoyant material is entrained in convergence zones associated with the leading edge of internal waves. Neustonic larvae found at the air-sea interface can become concentrated in these slicks and propagated shoreward (e.g., Shanks 1983 and 1988). This mechanism remains controversial, however, for the transport of non-neustonic larvae (Pineda 1994). An alternative mechanism has been hypothesized where water-column larvae are concentrated along an upwelled thermal front created by a breaking internal tidal bore, and subsequently moved shoreward (e.g., Pineda1994 and 1999; Leichter et al. 1996; mechanism detailed in Franks 1992; Epstein 1995; Yoder et al. 1994; Pineda 1999). The extent of horizontal transport depends on the vertical distribution of larvae relative to the thermocline and the distance of the thermocline from the shore.

\subsubsection{Biological and Physical Processes Influencing Vertical Distributions of Larvae}

The temporal and spatial gradients of food, light, predator and temperature distributions in the ocean are especially pronounced in the vertical dimension. Larvae must be able to respond - physiologically, morphologically and behaviorally — to such variability in order to survive, disperse, and ultimately recruit into adult populations (e.g., Young and 
Chia 1987; Young 1995). The ability to move vertically may be an important capacity in this regard.

When larvae occupy different vertical strata, alterations to biological rate processes occur. For example, depth-dependent mortality rates result from depthdependent concentrations of predators or food resources, and depth-dependent growth rates result from physiological responses to local temperature and feeding environments. Moreover, the vertical position of larvae may determine the direction and magnitude of transport. Vertical stratification of larvae in vertically sheared flows or in two-layer systems where currents run in opposite directions, can result in differential transport of the organisms (e.g., Hardy and Gunther 1933; Bowden 1965; Okubo 1967; Kullenberg 1972, 1977 and 1978; Kamykowski 1974). Both passive (i.e., larvae are non-swimming) and active movements of larvae can lead to vertical stratification of larvae.

Passively Distributed Larvae: Passive vertical stratification of planktonic larvae may result from biological or physical processes. For example, an increase in near-bottom larval concentration may result from spawning activities of local benthic invertebrates. Depth-dependant decreases in larval concentration may result from differential mortality via planktonic or benthic predation. Furthermore, natural, ontogenetic changes in larval density may occur through increased calcification of shell structures or depletion of lipidrich food reserves. Thus, many late-stage larvae may be found in near-bottom waters (Thorson 1964; Pennington and Emlet 1986; but, see Young 1995). 
Physical processes that tend to stratify larvae include depth-dependant turbulent mixing (indicated by shear stress, $\mathrm{u}_{*}$, due to waves, tides and currents), advection (e.g., vertically sheared currents), or density stratification. Turbulent mixing may be caused by meteorological events (e.g., winds, solar heating), waves, tidal forces, or interactions between current flow and irregular topography, and can redistribute larvae in the vertical dimension (MacIntyre et al. 1995). For example, Levin (1986) found passive resuspension of larvae during peak tidal flows (modeled by Gross et al. 1992). Turbulent mixing may cause larval patches to disperse (Koehl et al. 1993), but larvae are not simply redistributed as passive particles. Most invertebrate larvae are negatively-buoyant and sink at rates between 0.08 and $2.0 \mathrm{~cm} \mathrm{sec}^{-1}$ (e.g., Konstantinova 1966 and 1969; Mileikovski 1973; Chia et al. 1984; Gallager and Mann 1986; Butman et al. 1988; but see West and Costlow 1987), and, unless they swim, will eventually settle to the bottom once mixing or resuspension diminish. While there is a biological component (settling speed) involved, such movement is considered passive because larvae are not swimming and the forces of gravity are acting.

Vertical advection can result from upwelling or downwelling near a coastal boundary, the vertical flows associated with fronts and eddies, buoyant plumes, or the passage of an internal tide or wave (e.g., Haury et al. 1979; Horne and Platt 1984; Denman and Gargett 1995). For example, divergences within Gulf Stream meanders result in vertical velocities of approximately $50 \mathrm{~m} \mathrm{day}^{-1}$ (e.g., Chew et al. 1985; Hall 1986; Osgood et al. 1987; Bower and Rossby 1989; Bower 1989). 
Active Larval Behaviors: Vertical stratification of larvae may also result from an active behavioral response. On finer spatial scales (of order several to 100 's of m), interactions of individuals become important. Swimming speeds of meroplanktonic larval organisms (ca. $0.001-4.2 \mathrm{~cm} \mathrm{sec}^{-1}$; Mileikovsky 1973; Chia et al. 1984), while slower than those for larger zooplankters, are sufficient to accomplish active vertical migration on a diel basis (Mileikovsky 1973; Forward 1976; Chia et al. 1984; Mann et al. 1991) in waters 25 $\mathrm{m}$ to $1800 \mathrm{~m}$ deep, respectively. In fact, laboratory (e.g., Kaartvedt et al. 1987; Silva and O'Dor 1988; Barile et al. 1994; Gallager et al. 1996b; Manuel 1996) and field (e.g., Quayle 1952; Verwey 1966; Scrope-Howe and Jones 1986; Pennington and Emlet 1986; Tremblay and Sinclair 1990a and 1990b; Raby et al. 1994) observations suggest that vertical migrations occur on a diel cycle for many coastal invertebrate species. Yet, the applicability of these diel vertical migration studies to populations separated in time (daily or seasonally) and space remains unknown (e.g., Banse 1964, 1986). Moreover, Manuel et al. (1996) presented evidence that larvae from different populations of the same species display different vertical migration patterns.

The primary beneficial consequences of diel vertical migration for the survival of any planktonic organism include escape from predation and effective utilization of food resources in a heterogeneous environment (i.e., starvation-avoidance). Additional benefits include avoidance of certain deleterious environmental factors such as ultraviolet light or anoxia, and facilitation of horizontal transport favoring dispersal or retention depending on the larva's vertical position in vertically sheared flows. Whether these factors are causes or consequences of diel vertical migration remains to be determined. 
Planktivorous fish have the greatest impact on invertebrate larval mortality (Rumrill 1990; Morgan 1995b). Because the majority of these fish are visual feeders, many species of larval prey may be expected to undergo "normal" diel vertical migrations (i.e., nocturnal ascent; Forward 1976a, 1976b; Gliwicz 1986) as a defensive mechanism. Larvae rise to the surface at night when visual predators would be ineffective. "Reverse" migration may be a larval defense mechanism against predators that do not rely on visual cues while feeding (i.e., nocturnal descent; as documented in copepods by Ohman and Frost 1983).

When the maximum concentration of phytoplankton cells remains at a fixed depth - usually measured as the chlorophyll a maximum - either the larvae distribute themselves permanently in close proximity to the chlorophyll $a$ maximum, or larvae vertically migrate on a diel basis to the depth of the chlorophyll $a$ maximum. Thus, it would appear that identifying the utilization of food resources as the selective advantage of diel vertical migration may be somewhat incomplete; additional processes may be involved. For example, avoidance of predators or other deleterious environmental variables, such as ultraviolet light (a cue from surface waters) or hydrogen sulfide (a cue from bottom sediments), may also be influential (e.g., Damkaer et al. 1984; Pennington and Emlet 1986; Barile 1994), otherwise, larvae would have remained at the depth of the maximal feeding potential.

Finally, larval migrations may be synchronized with the tides; but, active migration may be difficult to distinguish from passive resuspension during peak tidal flows (see section 1.5.1; Levin 1986; Gross et al. 1992). Nevertheless, selective tidal 
transport has been proposed as a mechanism capable of producing net horizontal movement (Cronin and Forward 1982; Hill 1991a, 1991b and 1994; Rothlisberg et al. 1983; Thiébault et al. 1992), though no conclusive evidence supporting this mechanism has been collected for inner-shelf larval species. Pressure can serve as a synchronizing cue for larval response to a semidiurnal tide $\left(\mathrm{M}_{2}, 12.4 \mathrm{hr}\right.$; Knight-Jones 1966; Marsden 1994); however, a synchronizing cue for larval response to the diurnal tide (in the presence of a stronger semidiurnal tide) is less clear.

Rather than carrying out elaborate diel vertical migrations, larvae may simply respond a scalar environmental factor (e.g., temperature, salinity, turbulence, food, and predators) that is vertically stratified, and position themselves within a favorable water mass or microcosm (e.g., Banse 1986; Owen 1989). Larvae may display tactic responses to vector cues (i.e., light, gravity and current velocity), in which their response is directional relative to the cue (e.g., Thorson 1964; Cragg 1980; Mann and Wolf 1983; Mann 1986; Young 1995). Alternatively, larvae may display kinetic responses to scalar cues (i.e., temperature or salinity), thereby altering the fundamental rate of their swimming speeds (e.g., Hidu and Haskin 1978; Mann et al. 1991; Podolsky and Emlet 1993; Young 1995). Based on kinematic responses alone, vertical stratification of larvae is possible (Dekshenieks et al 1996). For example, a concentrated sub-pycnocline distribution would result if larvae swam (upward) under more-saline conditions and stopped swimming under less-saline conditions. Similarly, the distribution could be explained primarily by feeding activities. Bivalve larvae must swim in order to feed. 
Thus, bivalve larvae may swim upward while feeding, become satiated as they approach the thermocline, and begin to sink again as they stop feeding.

Seasonal or transient pycnoclines (e.g., thermoclines or haloclines) and boundary layers are oceanographic features in which there are large spatial gradients of environmental cues. These discontinuity layers are known sites of dense larval patches (e.g., Nelson 1928; Carriker 1951; Banse 1964; Harder 1968; Tremblay and Sinclair 1990b; Raby et al. 1994; Gallager et al. 1996b; Metaxas and Young 1998), zooplankton (e.g., Beeton 1960; Hansen 1951; Davis et al. 1992b) and phytoplankton (e.g., Harrison et al. 1983; Weeks et al. 1993). It has proven difficult to quantify movement of water across a pycnocline (e.g., Ledwell et al. 1993, 1998). Quantifying the effect of discontinuities on the vertical movement of organisms has been even more difficult because both the water and the organisms must be tracked. For example, it remains unknown whether larval patches at the pycnocline result from a mechanical response, such as increased viscosity at the pycnocline (e.g., Podolsky and Emlet 1993; Gallager in prep.), or from a behavioral response of the larvae. Preliminary evidence suggests that the vertical movements of some larval groups are limited by the presence of pycnoclines (e.g., Banse 1964; Harder 1968), whereas other groups are not limited and pass through the pycnocline (e.g., Harder 1968; Pennington and Emlet 1986; Mann et al. 1991). Inner-shelf circulation (i.e., wind-forced upwelling and downwelling), when acting on vertically and thermally stratified larval distributions, leads to differential larval transport. Positioning of larvae near the pycnocline may reduce the impact of winddriven cross-shelf currents on the transport of these larvae because flow speeds are 
typically very slow at the depth of flow reversal. Instead, there may be greater impact of other physical processes, such as internal tidal bores and episodic storm events, that displace the thermocline and larvae residing near it.

\subsection{OBJECTIVES AND APPRAOCH OF THESIS RESEARCH}

This thesis research quantifies spatial and temporal characteristics of invertebrate larvae distributions in an inner-shelf environment, evaluates to what extent planktonic distributions of invertebrate larvae are determined by larval behaviors and physical processes, and examines how differentially distributed larvae are advected to potential adult habitats by inner-shelf circulation such as wind-driven upwelling and downwelling. The specific research objectives are: (1) to quantify the time scales of variability in larval concentration at two sites on the inner shelf, lending better insight into the corresponding time scales of variability for recruitment into benthic communities; (2) to determine larval associations with different inner-shelf water masses and vertical distributions of larvae within those waters; (3) to elucidate the biological and physical mechanisms underlying the patterns of larval distribution; (4) to speculate on the ecological impact of larval distributions in the context of inner-shelf circulation patterns and larval transport to favorable adult habitats; and (5) to suggest how the results of this research might be used to guide future sampling efforts.

Meeting these objectives has required relatively high-frequency sampling of larvae over a relatively long period of time and with adequate vertical coverage. Thus, this research capitalized on two sets of larval concentration time series, collected by 
moored zooplankton pumps, and complemented by synoptic meteorological and hydrographic time-series data (see section 1.5). The specific objectives of this research were addressed using the following approach. First, variability in the timing and intensity of larval concentrations was quantified from direct time-series collections of larvae. Autocorrelation analyses of the time-series data provided a measure of the decorrelation times associated with each larval group. Chapter 2 focuses on variations in larval concentration occurring on time scales of hours to days, and Chapter 3 describes variations in larval concentration on time scales of hours to weeks. Next, spatial characteristics of larval distributions were quantified. Local water masses were identified through their temperature-salinity characteristics. Larval associations with different water masses, and their vertical distributions within these water masses were evaluated using vertically stratified time-series collections of larvae at a single inner-shelf site (Chapter 3) coupled with oceanographic data from instruments moored nearby. Biological and physical processes underlying the observed distributions were identified by coupling synoptic biological and physical time-series data (Chapter 2 and 3). Temporal variations and corresponding changes in the vertical structure of larval concentration were evaluated within the context of two major sources of variation in the data. A relatively "low-frequency" (of order several days) source of variation was associated with the synoptic meteorological time scale, and a relatively "high-frequency" source of variation was associated with the diurnal (24-hr) time scale. The fourth chapter summarizes the main results of this thesis research and discusses potential research for the future. 
In past studies temporal and vertical distributions of planktonic larvae have been inferred from settlement patterns (e.g., Roughgarden et al. 1991; Wing et al. 1995) or evaluated directly using non-synoptic 24- or 48-hr station data (e.g., Banse 1986; ScropeHowe and Jones 1986; Tremblay and Sinclair 1990) or samples collected at a single depth (e.g., Farrell et al. 1991; Miller and Emlet 1997; Chapter 2). In contrast, the foundation of the present study is the simultaneous collection of larvae at three depths by moored plankton pumps sampling every 3 hr over a 3-wk period. Thus, this study provides direct (versus inferred) measurements of larval concentration with increased vertical and temporal resolution over a relatively long period of time. In addition, extensive synoptic biological and physical data were collected during the present study, allowing a more detailed exploration into the potential role of physical and behavioral processes in modulating variations in larval concentration. Net tows have underestimated the variability in larval concentrations observed at the temporal and spatial scales of the present study. Time-series measurements of larval concentration have yielded a new perspective on the temporal and spatial variability in larval concentration at an innershelf site.

\subsection{DESCRIPTION OF COASTAL OCEAN PROCESSES} (“CoOP94”) FIELD STUDY*

The research presented here represents a small part of a much larger interdisciplinary study investigating the cross-shelf transport of invertebrate larvae (Butman 1994), which was funded by the NSF Coastal Ocean Processes (CoOP) Program. The field study 
(referred to by the acronym "CoOP94") was conducted over the inner continental shelf near Duck, North Carolina, USA (Fig. 1.3) and had intensive, 3-wk sampling periods in both August and October 1994.

A two-dimensional (i.e., cross-shelf and vertical) array of moored plankton pumps and hydrographic, meteorological, and sedimentological sensors was positioned across the inner shelf, from the surf zone out to $25 \mathrm{~m}$ depth (Fig. 1.4). The instruments were attached to moorings, towers, or tripods concentrated at five major sites: 4-m, 8-m, 13-m, 20-m and 25-m sites. A total of eight $\underline{\text { Moored, }}$ Automated, $\underline{\text { Serial }}$ Zooplankton $\underline{\text { Pumps }}$ (MASZP's; Fig. 1.5; Doherty and Butman 1990; Butman 1994) sampled at 3-hr intervals over the course of three weeks in both August and October 1994. The MASZP's were distributed among three cross-shelf locations positioned at the 8-, 20- and 25-m depth contours (Fig 1.4).

Hydrographic instruments sampled temperature, salinity, pressure, and current velocity nominally at 4-min sampling rates from July through November, 1994 (Fig. 1.4). Additionally, meteorological instruments - attached to surface moorings at the 25- and 20-m sites and to a pier adjacent to the 8 -m site - recorded wind velocity, short- and long-wavelength radiation, humidity and air temperature at 7.5-min sampling rates (Alessi et al. 1996). Instrumentation on bottom tetrapods at the 8- and 20-m sites collected data on current velocity and suspended sediment concentration every $4 \mathrm{hr}$. These data were used to make estimates of near-bottom flow, bottom-stress, and transport of suspended sediment. Thus, a fairly comprehensive description of the 


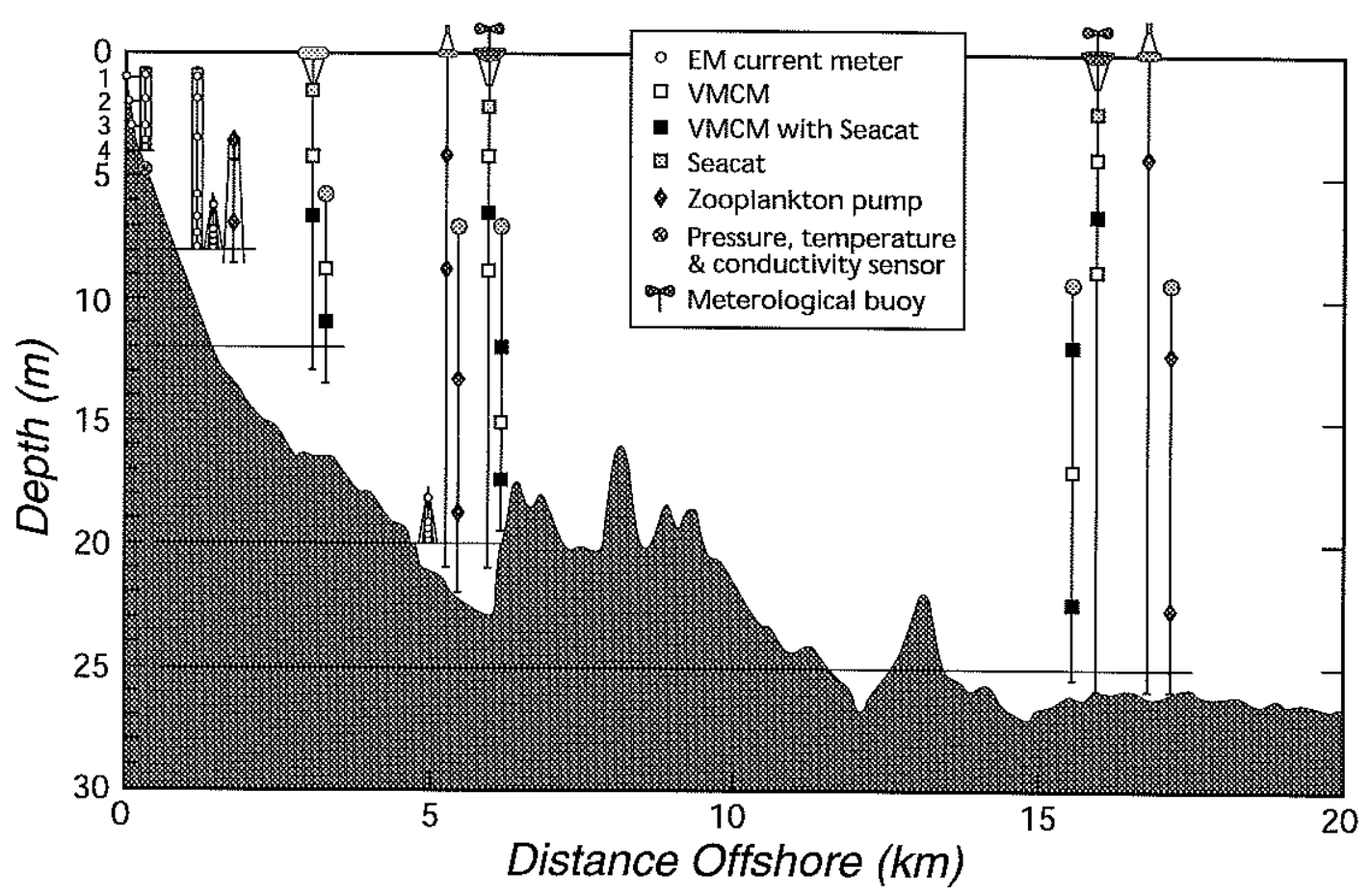

Figure 1.4 A schematic illustrating the CoOP94 Project cross-shelf instrument array during the August 1994 deployment. Instruments were concentrated at sites located along the 4-, 8-, 12-, 20-, and 25-m depth contours. The 8-m, 20-m and 25-m sites were located approximately 1,5 , and $17 \mathrm{~km}$ offshore, respectively. Key: EM, electromagnetic current meter; VMCM, vector-measuring current meter; Seacat, instrument measuring conductivity, temperature and depth. Physical, sedimentological and meteorological data were recorded primarily by R.T. Guza, S.J. Lentz, L.D. Wright and O.S. Madsen. Zooplankton collections were made by C.A. Butman. 
cross-shelf circulation was possible (Waldorf et al. 1995; Alessi et al. 1996; Fedderson et al. 1998; Shay et al. 1998; Austin 1999; Austin and Lentz 1999; Lentz et al. 1999; Lentz et al. in prep.; Rennie et al. 1999).

Shipboard biological and physical surveys, covering over $120 \mathrm{~km}$ alongshore and $50 \mathrm{~km}$ cross-shelf, complemented the time series measurements by adding a regional hydrographic perspective. Conductivity-temperature-depth recording (CTD) casts, Acoustic Doppler Current Profiler (ADCP) tows, and plankton sample collection (using a pump lowered from the surface to discrete depths) were done from the $R / V$ Cape Hatteras (Waldorf et al. 1995) and by a small boat launched from the beach ( $R / V M o b y$ Duck; Largier and Millikan 1996).

The research presented in Chapter 3 of this thesis focused on the August 1994 larval concentration time series collected by a vertical string of plankton pumps moored at the 20-m site, coupled with physical data collected nearby. Each time series of larval concentration consisted of 250-liter samples collected every $3 \mathrm{hr}$ over a 3 -wk period (August $11-30,1994$ ). Three pumps were positioned at 3.20, 8.72 and 12.25 meters above the bottom (mab).

A pilot study was conducted at the 8-m site at Duck, NC during the year prior to CoOP94. The objectives of the pilot study were to evaluate the performance of a redesigned MASZP (see Butman 1994) at the CoOP94 site, and to obtain some information on the scales of variability of larval abundance to help guide the sampling 


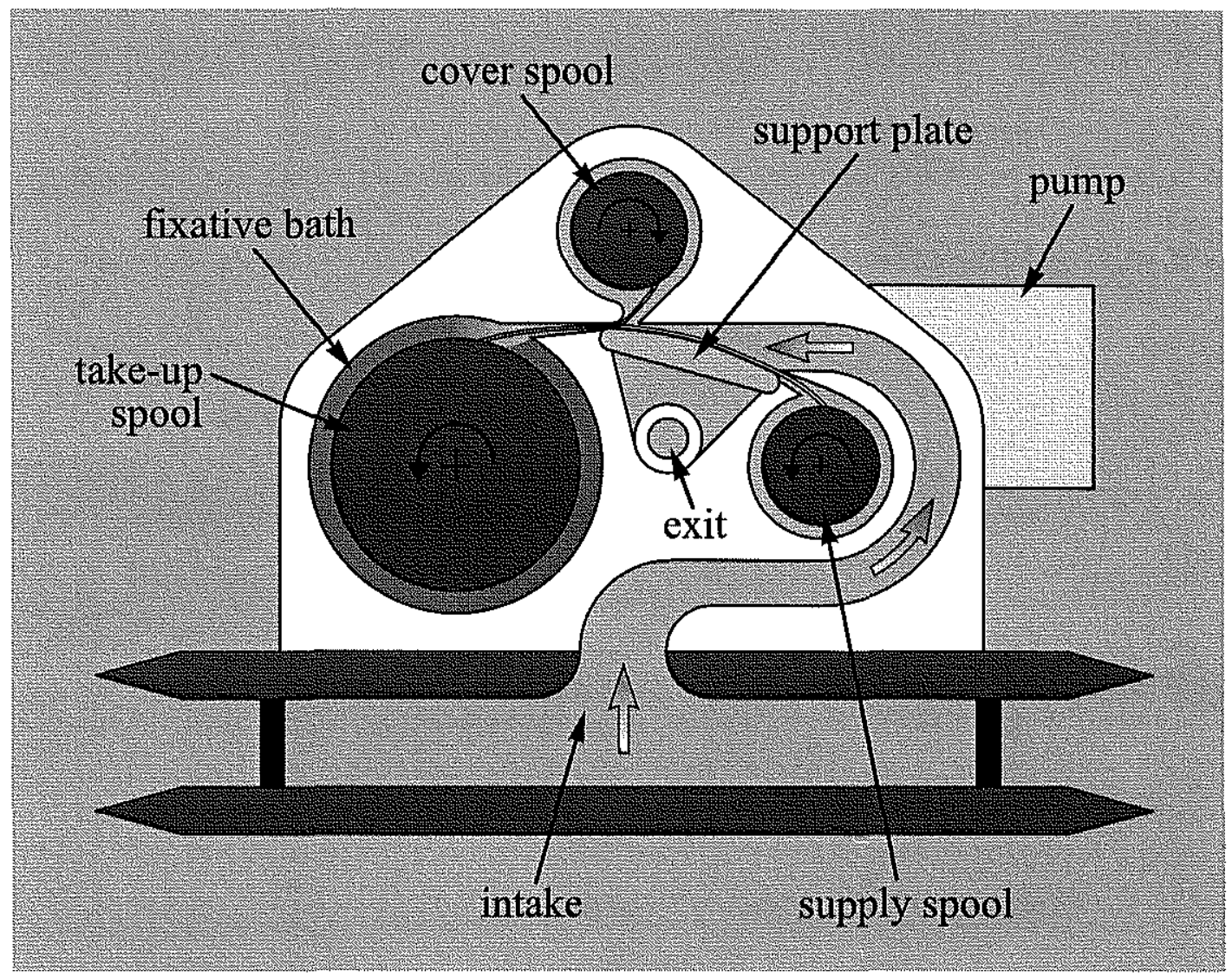

Figure 1.5 The Moored, Automated, Serial Zooplankton Pump (MASZP) was designed for extended (e.g., months) deployments and for direct sampling at relatively high (e.g., hours) frequencies. The unique features of the MASZP allow for sampling through inclement weather, such as storms and ice flows, that might otherwise restrict net tows or other ship-based sampling strategies. The hydrodynamically streamlined design of the MASZP minimizes disturbances to the oncoming flow, and thus to the organisms, permitting a slow intake velocity. The entrance region to the pump intake is formed by two horizontal circular plates with hydrodynamically streamlined circumferential edges. The ambient flow carries water (and organisms) between the plates, and sampling of this water mass is achieved by pumping up through a hole in the center of the upper plate. A positive-displacement pump draws water through the intake, which is spanned by a $1-\mathrm{mm}$ prefilter. Thus, organisms larger than 100 microns (i.e., the shortest dimension of the 100 -micron collection mesh) but smaller than 1415 microns (i.e., the longest dimension, or diagonal, of the 1-mm mesh prefilter) are retained. Once a discrete sample is collected, it is covered by another strip of 100 -micron mesh. The two strips, with the sample in between, are wound onto a take-up spool that resides in a 3.7\% formalin bath (buffered with CaCO3) for longterm storage in situ. ATattletale Model III computer functions as controller and data logger, driving a user-selected sampling schedule and recording sampling, instrument and environmental variables. In its present configuration, the instrument can take up to 160 samples per deployment, remain in the field for up to 6 months, and be deployed in water depths of up to $1,500 \mathrm{~m}$. 
scheme for the 1994 field project. A single pump collected seventy 500- or 1000-liter samples collected every hour over a 3-day period (July $19-23$, 1993). The pump intake was positioned at $0.8 \mathrm{mab}$ on a tripod deployed in $8 \mathrm{~m}$ of water. Time-series plankton pump samples from this study are the foundation for the research presented in Chapter 2 .

* Principal Investigators of the CoOP94 project were: C.A. Butman and S.J. Lentz (Woods Hole Oceanographic Institution), O.S. Madsen (Massachusetts Institute of Technology), R.T. Guza and J.L. Largier (Scripps Institution of Oceanography), A.L. Shanks (Oregon Institute of Marine Biology, University of Oregon), and L.D. Wright and J.M. Brubaker (Virginia Institute of Marine Science). 


\subsection{LITERATURE CITED}

Alessi, CS, Lentz S, Austin J (1996). Coastal Ocean Processes Inner Shelf Study: Coastal and moored physical oceanographic instruments. Woods Hole Oceanogr. Inst. Tech. Rpt. WHOI-96-06, 142 pp.

Austin JA (1999). The role of the alongshore wind stress in the heat budget of the North Carolina inner shelf. J. Geophys. Res. 104: 18187-18203.

Austin JA, Lentz SJ (1999). The relationship between synoptic weather systems and meteorological forcing on the North Carolina inner shelf. J. Geophys. Res. 104: 1815918185.

Bakun A (1996). Patterns in the Ocean: Ocean Processes and Marine Population Dynamics. California Sea Grant College System, National Oceanic and Atmospheric Administration, CA.

Banse K (1964). On the vertical distribution of zooplankton in the sea. Prog. Oceanogr. 2: $53-125$.

Banse K (1986). Vertical distribution and horizontal transport of planktonic larvae of echinoderms and benthic polychaetes in an open coastal sea. Bull. Mar. Sci. 39: 162175.

Barber RT, Smith RL (1981). Coastal upwelling ecosystems. In: Longhurst AR (ed.), Analysis of Marine Ecosystems. Academic Press, NY, pp. 31-68.

Barile PJ, Stoner AW, Young CM (1994). Phototaxis of the queen conch (Strombus gigas Linne) veliger larvae. J. Exp. mar. Biol. Ecol. 183: 147-162.

Beeton AM (1960). The vertical migration of Mysis relicta in Lakes Huron and Michigan. J. Fisheries Res. Bd. Can. 17: 517-539.

Boehlert GW, Mundy BC (1988). Roles of behavior and physical factors in larval and juvenile fish recruitment to estuarine nursery areas. In: Weinstein MP (ed.), Larval Fish and Shellfish Transport through Inlets. Amer. Fisheries Soc., MD, pp. 51-67.

Boicourt WC (1973). The circulation of water on the continental shelf from Chesapeake Bay to Cape Hatteras. Ph.D. Thesis, The Johns Hopkins University, Baltimore, MD.

Boicourt WC (1982). Estuarine larval retention mechanisms on two scales. In: Kennedy VS (ed.), Estuarine Comparisons. Academic Press, NY, pp. 445-457. 
Boicourt WC (1988). Recruitment dependence on planktonic transport in coastal waters. In: Rothschild BJ (ed.), Toward a Theory on Biological-Physical Interactions in the World Ocean. Kluwer Academic Publishers, Boston, MA, pp. 183-202.

Boicourt WC, Chao S-Y, Ducklow HW, Gilbert PM, Malone TC, Roman MR, Sanford LP, Fuhrman JA, Garside C, Garvine RW (1987). Physics and microbial ecology of a buoyant plume on the continental shelf. EOS, Trans. Amer. Geophys. Union. 68: 666668.

Bowden KF (1965). Horizontal mixing in the sea due to a shearing current. J. Fluid Mech. 21: 83-95.

Bower AS (1989). Potential vorticity balances and horizontal divergence along particle trajectories in Gulf Stream meanders east of Cape Hatteras. J. Phys. Oceanogr. 11: 1669-1681.

Bower AS, Rossby T (1989). Evidence of cross-frontal exchange processes in the Gulf Stream based on isopycnal RAFOS float data. J. Phys. Oceanogr. 19: 1177-1190.

Butman CA (1987). Larval settlement of soft-sediment invertebrates: The spatial scales of pattern explained by active habitat selection and the emerging rôle of hydrodynamical processes. Oceanogr. Mar. Biol. Ann. Rev. 25: 113-165.

Butman CA (1994). CoOP, Coastal Ocean Processes Study: Interdisciplinary approach, new technology to determine biological, physical, geological processes affecting larval transport on the inner shelf. Sea Technol. 35: 44-49.

Butman CA, Doherty KW, Longworth SP, Clifford CH (In prep). A new, moored, automated, serial, zooplankton pump. I. Description and flume studies of collection characteristics. (for J. Mar. Res.).

Butman CA, Grassle JP, Buskey EJ (1988). Horizontal swimming and gravitational sinking of Capitella sp. I (Annelida: Polychaeta) larvae: Implications for settlement. Ophelia 29: 43-57.

Carriker MR (1951). Ecological observations on the distribution of oyster larvae in New Jersey estuaries. Ecol. Monogr. 21: 19-38.

Chereskin TK (1983). Generation of internal waves in Massachusetts Bay. J. Geophys. Res. 8: 2469-2661.

Chew F, Bane JM Jr., Brooks DA (1985). On vertical motion, divergence, and the thermal wind balance in cold-dome meanders: A diagnostic study. J. Geophys. Res. 90: 3173-3183. 
Chia F-S, Buckland-Nicks J, Young CM (1984). Locomotion of marine invertebrate larvae: a review. Can. J. Zool. 62: 1205-1222.

Coleman JS (1933). The nature of the intertidal zonation of plants and animals. J. Mar. Biol. Assoc. UK 18: 345-476.

Connell JH (1985). The consequences of variation in initial settlement vs. postsettlement mortality in rocky intertidal communities. J. Exp. Mar. Biol. Ecol. 93: 11-45.

Connolly SR, Roughgarden J (1999). Increased recruitment of northeast Pacific barnacles during the 1997 El Niño. Limnol. Oceanogr. 44: 466-469.

Cragg SM (1980). Swimming behaviour of the larvae of Pecten maximus (L.) (Bivalvia). J. Mar. Biol. Ass. U.K. 60: 551-564.

Cronin TW, Forward RB Jr. (1982). Tidally timed behavior: Effects on larval distributions in estuaries. In: Kennedy VS (ed.), Estuarine Comparisons. Academic Press, Inc, NY, pp. 505-519.

Damkaer DM, Dey DB, Heron GA, Prentice EF (1980). Effects of UV-B radiation on near-surface zooplankton of Puget Sound. Ecol. 44: 149-158.

Davis CS, Flierl GR, Wiebe PH, Franks PJS (1991). Micropatchiness, turbulence and recruitment in plankton. J. Mar. Res. 49: 109-151.

Davis CS, Gallager SM, Solow AR (1992b). Microaggregations of oceanic plankton observed by towed video microscopy. Science 257: 230-232.

Dekshenieks MM, Hofmann EE, Klink JM, Powell EN (1996). Modeling the vertical distribution of oyster larvae in respect to environmental conditions. Mar. Ecol. Progr. Ser. 136: 97-110.

Denman KL, Gargett AE (1995). Biological-physical interactions in the upper ocean: The role of vertical and small scale transport processes. Annu. Rev. Fluid Mech. 27: 225-255.

Dickey TD (1990). Physical-optical-biological scales relevant to recruitment in large marine ecosystems. In: Sherman K, Alexander LM, Gold BD (eds.), Large Marine Ecosystems. Patterns, Processes, and Yields. American Association for the Advancement of Science, Washington, DC, pp. 82-98.

Dixon PA, Milicich MJ, Sugihara G (1999). Episodic fluctuations in larval supply. Science. 283: 1528-1530. 
Doherty KW, Butman CA (1990). A time- or event-triggered, automated, serial, plankton-pump sampler. In: Frye D, Stone E, Martin A (eds.), Advanced Engineering Laboratory Projects Summaries - 1989, WHOI Tech. Rept. 90-20, pp. 15-23.

Ekman VW (1905). On the influence of the earth's rotation on ocean-currents. Arkiv. för matematik, astronomi o. fysik. 2(11): 1-53.

Emlet RB (1986). Larval production, dispersal, and growth in a fjord: A case study on larvae of the sand dollar Dendraster excentricus. Mar. Ecol. Prog. Ser. 31: 245-254.

Epifanio CE (1988). Transport of invertebrate larvae between estuaries and the continental shelf. In: Weinstein MP (ed.), Larval Fish and Shellfish Transport through Inlets. Amer. Fisheries Soc., MD, pp. 104-114.

Epstein AW (1995). Physical processes and zooplankton distribution in the Great South Channel: observational and numerical studies. MIT/WHOI Joint Program in Oceanography. Ph.D. Dissertation. MIT/WHOI 95-09.

Farrell TM, Bracher D, Roughgarden J (1991). Cross-shelf transport causes recruitment to intertidal populations in central California. Limnol. Oceanogr. 36: 279-288.

Fedderson F, Guza RT, Elgar S, Herbers THC (1998). Alongshore momentum balances in the nearshore. J. Geophys. Res. 103: 15667-15676.

Forward RB Jr (1976a). Light and vertical migration: photobehavior and photophysiology of plankton. Photochem. Photobiol. Rev. 1: 157-209.

Forward RB Jr (1976b). Light and diurnal vertical migration: Photobehavior and photophysiology of plankton. In: Smith KC (ed.), Photochemical and Photobiological Reviews, Vol. 1. Plenum Press, NY. pp. 157-209.

Franks PJS (1992). Swim or sink: Accumulation of biomass at fronts. Mar. Ecol. Prog. Ser. 82: 1-12.

Gaines SD, Brown S, Roughgarden J (1985). Spatial variation in larval concentrations as a cause of spatial variation in settlement for the barnacle, Balanus glandula. Oecologia 67: $267-272$.

Gallager SM, Mann R (1986). Growth and survival of larvae of Mercenaria mercenaria (L.) and Crassostrea virginica (Gmelin) relative to broodstock conditioning and lipid content of eggs. Aquaculture. 56: 105-121. 
Gallager SM, Manuel JL, Manning DA, O'Dor R (1996b). Ontogenetic changes in the vertical distribution of giant scallop larvae, Placopecten magellanicus, in 9-m deep mesocosms as a function of light, food, and temperature stratification. Mar. Biol. 124: 679-692.

García-Moliner G, Mason DM, Greene CH, Lobo A, Li B-I, Wu J, Bradshaw GA (1993). Description and analysis of spatial patterns. In: Levin SA, Powell TM, Steele JH (eds.), Patch Dynamics. Lecture Notes in Biomathematics. Springer-Verlag, NY, pp. 70-89.

Garrett CJR, Munk WH (1972). Space-time scales of internal waves. Geophys. Fluid Dyn. 3: 225-264.

Garrett CJR, Munk WH (1975). Space-time scales of internal waves: a progress report. J. Geophys. Res. 80: 291-298.

Garvine RW (1986). The role of brackish plumes in open shelf waters. Nato Adv. Stud. Inst. Ser., Ser. G, Ecol. Sci. 7: 47-66.

Gliwicz MZ (1986). Predation and evolution of vertical migration in zooplankton. Nature. 320: 746-748.

Goodrich DM, Van Montfrans J, Orth RJ (1989). Blue crab megalopal influx to Chesapeake Bay: Evidence for a wind-driven mechanism. Estuar. Coast. Shelf Sci. 29: 247-260.

Grantham BA (1997). Coastal upwelling, larval recruitment, and the dynamics of upper intertidal barnacle communities. Ph.D. thesis, Stanford University, CA.

Grosberg RK (1982). Intertidal zonation of barnacles: the influence of planktonic zonation of larvae on vertical distribution of adults. Ecol. 63: 894-899.

Gross TF, Werner FE, Eckman JE (1992). Numerical modeling of larval settlement in turbulent bottom boundary layers. J. Mar. Res. 50: 611-642.

Haeckel E (1883). Planktonic studies: a comparative investigation of the importance and constitution of the pelagic fauna and flora. U.S. Comm. Fish. Fisheries Rpt. 1891: 565641.

Hall MM (1986). Horizontal and vertical structure of the Gulf Stream velocity field at 68 degrees W. J. Phys. Oceanogr. 16: 1814-1828.

Hansen KW (1951). On the diurnal migration of zooplankton in relation to the discontinuity layer. J. Conseil, Conseil Perm. Intern. Explor. Mer. 17: 231-241. 
Harder W (1968). Reactions of plankton organisms to water stratification. Limnol. Oceanogr. 13(1): 156-168.

Hardy AC, Gunther ER (1935). The plankton of the South Georgia whaling grounds and adjacent water, 1926-1927. Discovery Rpt. 11: 1-456.

Harrison PJ, Fulton JD, Taylor FJR, Parsons TR (1983). Review of the biological oceanography of the Strait of Georgia: Pelagic environment. Can. J. Fish. Aquat. Sci. 40: 1064-1094.

Haury LR, Briscoe MG, Orr MH (1979). Tidally generated internal wave packets in Massachusetts Bay. Nature 278: 312-317.

Haury LR, McGowan JA, Wiebe PH (1978). Patterns and processes in the time-space scales of plankton distributions. In: Steele JH (ed.), Spatial Pattern in Plankton Communities. Plenum Press, NY, pp. 277-327.

Hidu H, Haskin HH (1978). Swimming speeds of oyster larvae Crassostrea virginica in different salinities and temperatures. Estuaries 4: 252-255.

Hill AE (1991a). A mechanism for horizontal zooplankton transport by vertical migration in tidal currents. Mar. Biol. 111: 485-492.

Hill AE (1991b). Vertical migration in tidal currents. Mar.Ecol. Progr. Ser. 75: 39-54.

Hill AE (1994). Horizontal zooplankton dispersal by diel vertical migration in S2 tidal currents on the northwest European continental shelf. Cont. Shelf Res. 14: 491-506.

Hobbs RC, Botsford LW, Thomas A (1992). Influence of hydrographic conditions and wind forcing on the distribution and abundance of Dungeness crab, Cancer magister, larvae. Can. J. Fish. Aquat. Sci. 49: 1379-1388.

Horne EPW, Platt T (1984). The dominant space and time scales of variability in the physical and biological fields on continental shelves. Rapp. Proces. Verb. Cons. Int. Explor. Mer. 183: 9-19.

Johnson DF (1985). The distribution of brachyuran crustacean megalope in the waters of the New York River, lower Chesapeake Bay and adjacent shelf: Implications for recruitment. Est. Coastal Shelf Sci. 20: 693-705.

Jørgensen CB (1981). Mortality, growth, and grazing impact of a cohort of bivalve larvae, Mytilus edulis L. Ophelia 20: 185-192. 
Kaartvedt S, Aksnes DL, Egge JK (1987). Effect of light on the vertical distribution of Pecten maximus larvae. Mar. Ecol. Progr. Ser. 40: 195-197.

Kamykowski D (1974). Possible interactions between phytoplankton and semi-diurnal internal tides. J. Mar. Res. 32: 67-89.

Kingsford MJ (1990). Linear oceanographic features: A focus for research on recruitment processes. Austr. J. Ecol. 15: 391-401.

Knight-Jones EW, Morgan E (1966). Responses of marine animals to changes in hydrostatic pressure. Oceanogr. Mar. Biol. Ann. Rev. 4: 267-299.

Koehl MAR, Powell TM, Dairiki G (1993). Measuring the fate of patches in the water: Larval dispersal. In: Levin SA, Powell TM, Steele JH (eds.), Patch Dynamics. Lecture Notes in Biomathematics, Springer-Verlag, NY, pp. 50-60.

Konstantinova MI (1966). Characteristics of movement of pelagic larvae of marine invertebrates. Dokl. Akad. Nauk. SSSR. 170: 726-729.

Konstantinova MI (1969). Movement of polychaete larvae. Dokl. Akad. Nauk. SSSR. 188: 942-945.

Kullenberg GEB (1972). Apparent horizontal diffusion in stratified vertical shear flow. Tellus. 24: 17-28.

Kullenberg GEB (1977). Entrainment velocity in natural stratified vertical shear flow. Est. Coast. Mar. Sci. 5: 329-338.

Kullenberg GEB (1978). Vertical processes and the vertical-horizontal coupling. In: Steele JH (ed.), Spatial Pattern in Plankton Communities. Plenum Press, NY, pp. 43-71.

Largier JL, Millikan KS (1996). Coastal Ocean Processes (CoOP) Pilot Project Data Report: August - October 1994, R/V Moby Duck CTD and Underway Data. Scripps Inst. Oc. Ref. Ser. No. 96-29

Ledwell JR, Watson AJ, Law CS (1993). Evidence for slow mixing across the pycnocline from an open-ocean tracer-release experiment. Nature. 364: 701-703.

Ledwell JR, Watson AJ, Law CS (1998). Mixing of a tracer in the pycnocline. J. Geophys. Res. 103: 21,499-21,529.

Le Fèvre J (1986). Aspects of the biology of frontal systems. Adv. Mar. Biol. 23:163299. 
Legendre L, Demers S (1984). Towards dynamic biological oceanography and limnology. Can. J. Fish Aquat. Sci. 41: 2-19.

Leichter JJ, Wing SR, Miller SL, Denny MW (1996). Pulsed delivery of subthermocline water to Conch Reef (Florida Keys) by internal tidal bores. Limnol Oceanogr. 41: 14901501.

Lentz SJ, Carr M, Herbers THC (in prep). Barotropic tides on the North Carolina shelf. (for J. Geophys. Res.)

Lentz SJ, Guza RT, Elgar S, Feddersen F, Herbers THC (1999). Momentum balances on the North Carolina inner shelf. J. Geophys. Res. 104: 18205-18226.

Levin LA (1986). The influence of tides on larval availability in shallow waters overlying a mudflat. Bull. Mar. Sci. 39: 224-233.

Levin LA (1990). A review of methods for labeling and tracking marine invertebrate larvae. Ophelia 32: 115-144.

Levin LA, Huggett DV (1993). Rare-earth tagging methods for the study of larval dispersal by marine invertebrates. Limnol. Oceanogr. 38: 346-360.

Levin SA, Powell TM, Steele JH, eds. (1993) Patch Dynamics. Lecture Notes in Biomathematics, SpringeVerlag, NY.

MacIntyre S, Alldredge AL, Gotschalk CC (1995). Accumulation of marine snow at density discontinuities in the water column. Limnol. Oceanogr. 40: 449-468.

Mackas DL, Denman KL, Abbott MR (1985). Plankton patchiness: Biology in the physical vernacular. Bull. Mar. Sci. 37: 652-674.

Mann KH, Lazier JRN (1991). Dynamics of Marine Ecosystems: Biological-Physical Interactions in the Oceans. Blackwell Scientific Publications, Boston, MA.

Mann R (1986). Sampling of bivalve larvae. In: Jamieson GS, Bourne N (eds.), North Pacific Workshop on Stock Assessment and Management of Invertebrates, Can. Spec. Publ. Fish. Aquat. Sci. 92: 107-116.

Mann R (1988). Field studies of bivalve larvae and their recruitment to the benthos: A commentary. J. Shell. Res. 7: 7-10.

Mann R, Campos BM, Luckenbach MW (1991). Swimming rate and responses of larvae of three mactrid bivalves to salinity discontinuities. Mar. Ecol. Prog. Ser. 68: 257-269. 
Mann R, Wolf CC (1983). Swimming behavior of larvae of the ocean quahog Arctica islandica in response to pressure and temperature. Mar. Ecol. Prog. Ser. 13: 211-218.

Manuel JL (1996). Population and temporal variations in the vertical migrations of scallop (Placopecten magellanicus) veligers. Ph.D. thesis, Dalhousie University, Halifax, Nova Scotia, Canada.

Manuel JL, Gallager SM, Pearce CM, Manning DA, O'Dor RK (1996). Veligers from different populations of sea scallop Placopecten magellanicus have different vertical migration patterns. Mar. Ecol. Prog. Ser. 142: 147-163.

Marsden JR (1994). Vertical movements and distribution of planktonic larvae of the serpulid polychaete Spirobranchus polycerus (Schmarda); effects of changes in hydrostatic pressure. J. Exp. Mar. Biol. Ecol. 176: 87-105.

Metaxas A, Young CM (1998). Behaviour of echinoid larvae around sharp haloclines: Effects of the salinity gradient and dietary conditioning. Mar. Biol. 131: 443-459.

Mileikovsky SA (1973). Speed of active movement of pelagic larvae of marine bottom invertebrates and their ability to regulate their vertical position. Mar. Biol. 23: 11-17.

Miller BA, Emlet RB (1997). Influence of nearshore hydrodynamics on larval abundance and settlement of sea urchins Strongylocentrotus franciscanus and $S$. purpuratus in the Oregon upwelling zone. Mar. Ecol. Prog. Ser. 148: 83-94.

Minchinton TE, Scheibling RE (1991). The influence of larval supply and settlement on the population structure of barnacles. Ecol. 72: 1867-1879.

Morgan SG (1995a). The Timing of Larval Release. In: McEdward LR (ed.), Ecology of Marine Invertebrate Larvae. CRC Press, Inc., Boca Raton, FL, pp. 157-191.

Morgan SG (1995b). Life and death in the plankton: larval mortality and adaptation. In: McEdward LR (ed.), Ecology of Marine Invertebrate Larvae. CRC Press, Inc., Boca Raton, FL, pp. 279-321.

Mullineaux LS, Wiebe PH, Baker ET (1995). Larvae of benthic invertebrates in hydrothermal vent plumes over Juan de Fuca Ridge. Mar. Biol. 122: 585-596.

Nelson TC (1928). On the formation of saliniclines in Barnegat Bay, New Jersey, with observations of the reactions of oyster larvae to salinity gradients. Anat. Record. 41: 8485 .

Ohman MD, Frost BW, Cohen EB (1983). Reverse diel vertical migration: an escape from invertebrate predators. Science. 220: 1404-1407. 
Okubo A (1967). The effect of shear in an oscillatory current on horizontal diffusion from an instantaneous source. Int. J. Oceanol. Limnol. 1: 194-204.

Osgood KE, Bane JM, Dewar WK (1987). Vertical velocities and dynamical balances in Gulf Stream meanders. J. Geophys. Res. 92: 12,029-13,040.

Owen RW (1989). Microscale and finescale variations of small plankton in coastal and pelagic environments. J. Mar. Res. 47: 197-240.

Pennington JT, Emlet RB (1986). Ontogenetic and diel vertical migration of a planktonic echinoid larva, Dendraster excentricus (Eschscholtz): occurrence, causes, and probable consequences. J. Exp. Mar. Biol. Ecol. 104: 69-95.

Peterson CH (1986). Enhancement of Mercenaria mercenaria densities in seagrass beds: is pattern fixed during settlement season or altered by subsequent differential survival? Limnol. Oceanogr. 31: 200-205.

Pietrafesa LJ, Janowitz GS (1988). Physical oceanographic processes affecting larval transport around and through North Carolina inlets. In: Weinstein MP (ed.), Larval Fish and Shellfish Transport through Inlets. Amer. Fisheries Soc, MD, pp. 34-50.

Pineda J (1991). Predictable upwelling and the shoreward transport of planktonic larvae by internal tidal bores. Science 253: 548-551.

Pineda J (1994). Internal tidal bores in the nearshore: Warm-water fronts, seaward gravity currents and the onshore transport of neustonic larvae. J. Mar. Res. 52: 427-458.

Pineda J (1995). An internal tidal bore regime at nearshore stations along western USA: predictable upwelling within the lunar cycle. Cont. Shelf. Res. 15: 1023-1041.

Pineda J (1999). Circulation and larval distribution in internal tidal bore warm fronts. Limnol. Oceanogr. 44:1400-1414.

Podolsky RD, Emlet RB (1993). Separating the effects of temperature and viscosity on swimming and water movement by sand dollar larvae (Dendraster excentricus). J. Exp. Biol. 176: 207-221.

Pond S, Pickard GL (1983). Introductory Dynamical Oceanography, $2^{\text {nd }}$ ed. Pergamon Press, NY.

Powell TM (1989). Physical and biological scales of variability in lakes, estuaries, and the coastal ocean. In: Roughgarden J, May RM, Levin SA (eds.), Perspectives in Ecological Theory. Princeton University Press, Princeton, NJ, pp. 157-176. 
Prytherch HF (1929). Investigation of the physical conditions controlling spawning of oysters and the occurrence, distribution, and settling of oyster larvae in Milford Harbor, Connecticut. Bull. US Bur. Fish. 44: 429-503.

Quayle DB (1952). Structure and biology of the larva and spat of Venerupis pullastra (Montagu). Trans. R. Soc. Edinb. 62: 255-297.

Raby D, Lagadeuc Y, Dodson JJ, Mingelbier M (1994). Relationship between feeding and vertical distribution of bivalve larvae in stratified and mixed waters. Mar. Ecol. Progr. Ser. 103: 275-284.

Rennie S, Largier JL, Lentz SJ (1999). Observations of pulsed buoyancy current downstream of Chesapeake Bay. J. Geophys. Res. 104: 18227-18240.

Richards FA, ed. (1981). Coastal Upwelling. Coastal and Estuarine Sciences 1, American Geophysical Union, Washington, DC.

Rothlisberg PC, Church JA, Forbes AMG (1983). Modeling the advection of vertically migrating shrimp larvae. J. Mar. Res. 41: 511-538.

Rothschild BJ (1988). Biodynamics of the sea: The ecology of high dimensionality systems. In: Rothschild BJ (ed), Toward a Theory on Biological-Physical Interactions in the World Ocean. Kluwer Academic Publishers, Boston, MA, pp. 527-548.

Rothschild BJ, ed. (1988). Toward a Theory on Biological-Physical Interactions in the World Ocean. Kluwer Academic Publishers, Boston, MA.

Roughgarden J, Gaines SD, Pacala SW (1987). Supply side ecology: The role of physical transport processes. In: Gee JHR, Giller PS (eds.), Organization of Communities Past and Present. The $27^{\text {th }}$ Symposium of the Brittish Ecological Society, Aberystwyth, 1986. Blackwell Scientific Publications, Boston, MA, pp. 491-518.

Roughgarden J, Gaines S, Possingham H (1988). Recruitment dynamics in complex life cycles. Science 241: 1460-1466.

Roughgarden J, Pennington JT, Stoner D, Alexander S, Miller K (1991). Collisions of upwelling fronts with the intertidal zone: The cause of recruitment pulses in barnacle populations of central California. Acta Oecologia 12: 35-51.

Rumrill SS (1990). Natural mortality of marine invertebrate larvae. Ophelia. 32: 163198. 
Scheltema RS (1986). On dispersal and planktonic larvae of benthic invertebrates: An eclectic overview and summary of problems. Bull. Mar. Sci. 39: 290-322.

Scrope-Howe S, Jones DA (1986). The vertical distribution of zooplankton in the western Irish Sea. Est. Coast. Shelf Sci. 22: 785-802.

Shanks AL (1983). Surface slicks associated with tidally forced internal waves may transport pelagic larvae of benthic invertebrates and fishes shoreward. Mar. Ecol. Progr. Ser. 13: 311-315.

Shanks AL (1988). Further support for the hypothesis that internal waves can cause shoreward transport of larval invertebrates and fish. Fish. Bull. 86: 703-714.

Shanks AL (1995). Mechanisms of cross-shelf dispersal of larval invertebrates and fish. In: McEdward LR (ed.), Ecology of Marine Invertebrate Larvae. CRC Press, Inc, Boca Raton, FL, pp. 323-367.

Shanks AL, Wright WG (1987). Internal-wave-mediated shoreward transport of cyprids, megalopae, and gammarids and correlated longshore differences in the settling rate of intertidal barnacles. J. Exp. Mar. Biol. Ecol. 114: 1-13.

Shay LK, Lentz SJ, Graber HC, Haus BK (1998). Current structure variations detected by high-frequency radar and vector-measuring current meters. J. Atmos. Oceanic Technol. 15: 237-256.

Shkedy YD, Roughgarden J (1997). Barnacle recruitment and population dynamics predicted from coastal upwelling. Oikos 80: 487-498.

Silva MA, O'Dor RK (1988). Active depth regulation by the sea scallop larvae of Placopecten magellanicus? Bull. Can. Soc. Zool. 19: 36. (Abstract).

Smith RL (1968). Upwelling. Mar. Biol. Annu. Rev. 6: 11-46.

Stommel H (1963). Varieties of oceanographic experience. Science 139: 572-576.

Taggart CT, Frank KT 1990. Perspectives on larval fish ecology and recruitment processes. Probing the scales of relationships. In: Sherman K, Alexander LM, Gold BD (eds.), Large Marine Ecosystems. Patterns, Processes and Yields. American Association for the Advancement of Science, Washington, DC, pp. 151-164.

Taggart CT, Leggett WC (1987). Wind-forced hydrodynamics and their interaction with larval fish and population abundance: A time-series analysis of physical-biological data. Can. J. Fish. Aquat. Sci. 44: 438-451. 
Tegner MJ, Butler RA (1985). Drift-tube study of the dispersal potential of green abalone (Haliotis fulgens) larvae in the southern California Bight: Implications for recovery of depleted populations. Mar. Ecol. Prog. Ser. 26: 73-84.

Thiébault E, Dauvin J-C, Lagadeuc Y (1992). Transport of Owenia fusiformis larvae (Annelida: Polychaeta) in the Bay of Seine. I. Vertical distribution in relation to water column stratification and ontogenic vertical migration. Mar. Ecol. Prog. Ser. 80: 29-39.

Thorson G (1950). Reproductive and larval ecology of marine bottom invertebrates. Biol. Rev. Camb. Philos. Soc. 25: 1-45.

Thorson $\mathrm{G}$ (1964). Light as an ecological factor in the dispersal and settlement of larvae of marine bottom invertebrates. Ophelia. 1(1): 167-208.

Tremblay MJ, Sinclair M (1990a). Diel vertical migration of sea scallop larvae Placopecten magellanicus in a shallow embayment. Mar. Ecol. Prog. Ser. 67: 19-25.

Tremblay MJ, Sinclair M (1990b). Sea scallop larvae Placopecten magellanicus on Georges Bank: vertical distribution in relation to water column stratification and food. Mar. Ecol. Prog. Ser. 61: 1-15.

Underwood AJ, Fairweather PG (1989). Supply-side ecology and benthic marine assemblages. Trends Ecol. Evol. 4: 16-20.

Verwey $J$ (1966). The role of some external factors in the vertical migration of marine animals. Neth. J. Sea Res. 3:245-266.

Waldorf BW, Largier JL, Rennie S, Austin J, Greengrove S (1995). Coastal Ocean Processes (CoOP) pilot project data report: R/V Cape Hatteras shipboard measurements; underway CTD and ADCP data, August 1994. Scripps Inst. Oc. Ref. Ser. No. 95-29

Weeks A, Conte MH, Harris RP, Bedo A, Bellan I, Burkill PH, Edwards ES, Harbour DS, Kennedy H, Llewellyn C, Mantoura RCF, Morales CE, Pomroy AJ, Turley CM (1993). The physical and chemical environment and changes in community structure associated with bloom evolution: The Joint Global Flux Study North Atlantic Bloom Experiment. Deep-Sea Res. II. 40: 347-368.

West TL, Costlow JD (1987). Size regulation in larvae of the crustacean Balanus eburneus (Cirripedia: Thoracica). Mar. Biol. 96: 47-58.

Wing SR, Largier JL, Botsford LW, Quinn JF (1995a). Settlement and transport of benthic invertebrates in an intermittent upwelling region. Limnol. Oceanogr. 40: 316329. 
Wing SR, Largier JL, Botsford LW, Quinn JF (1995b). Spatial structure of relaxation events and crab settlement in the northern California upwelling system. Mar. Ecol.

Progr. Ser. 128: 199-211.

Yoder JA, Ackleson SG, Barber RT, Flament P, Balch WM (1994). A line in the sea. Nature 371: 689-692.

Young CM (1990). Larval ecology of marine invertebrates: A sesquicentennial history. Ophelia 32: 1-48.

Young CM (1995). Behavior and locomotion during the dispersal phase of larval life. In: McEdward LR (ed.), Ecology of Marine Invertebrate Larvae. CRC Press, Boca Raton, FL, pp. 249-277.

Young CM, Chia F-S (1987). Abundance and distribution of pelagic larvae as influenced by predation, behavior, and hydrographic factors. In: Giese AC, Pearse JS, Pearse VB (eds.), Reproduction of Marine Invertebrates. Blackwell Scientific Publications, Palo Alto and The Boxwood Press, Pacific Grove, CA, pp. 385-463. 


\section{CHAPTER 2}

Planktonic Larval Concentrations in a Nearshore Environment:

Temporal Variability on Scales of Hours to Days 


\begin{abstract}
:
To gain insight into the processes responsible for variations in planktonic larval availability over time scales of hours to days, zooplankton were collected hourly for $70 \mathrm{hr}$ with a time-series pump moored within a meter of the bed in $8 \mathrm{~m}$ of water. High variability in concentration was observed for all larval groups (gastropods, bivalves, barnacle cyprids, polychaetes and bryozoan cyphonautes). For all larvae except polychaetes, decorrelation times were $5-7 \mathrm{hr}$, indicating that sampling every $2.5-3.5 \mathrm{hr}$ was sufficient to capture the majority of the temporal variability in these groups. Sampling at an interval of $<1 \mathrm{hr}$ would be required for the polychaetes because the time series exhibited steeper peaks in concentration.

All of the larval groups displayed nearly coincident maximal and submaximal abundance peaks, suggesting temporal variability was driven by a similar mechanism(s). Temporal variations in larval concentrations could be explained by two hypotheses. The first is a physically motivated explanation, involving larval transport in wind-driven cross-shelf flows (e.g., upwelling and downwelling). Maximal and submaximal peaks in larval concentration occurred exclusively in cool, salty upwelled water, whereas concentrations were always low in warmer, less-saline downwelled water. Although larvae were most abundant during a period when cool upwelled water was near the pump, their near-bottom peaks in abundance coincided with periods of relaxation from upwelling which were followed by brief pulses of downwelling-favorable winds. Significant negative cross-correlations existed between larval concentration time series and the alongshore component of wind velocity. Thus, these findings suggest that larvae tracked with the colder water mass and were transported and concentrated onshore during upwelling conditions, but were delivered to the bottom when strong upwelling winds relaxed. The second hypothesis involves active vertical migration on a diel cycle. During the cold-water period, peaks in larval concentration occurred near noon, a pattern consistent with diel vertical migration (nocturnal ascent). Although the peaks were not separated by exactly $24 \mathrm{hr}$, strong advective perturbations may have disrupted temporarily the natural vertical migrations exhibited by larvae.

This study generated data that may be explained by two or more different mechanisms, however longer time series and greater vertical coverage are required to evaluate the alternative scenarios.
\end{abstract}




\subsection{INTRODUCTION}

In temperate latitudes, many species of benthic invertebrates possess a planktonic larval stage that disperses for hours to months before returning to a suitable adult habitat (Fig.

1.1). Larval supply to benthic habitats may be a continuous process, bathing the shorelines in a homogenous pool of larvae. In this case, post-settlement processes - such as predation, physiological tolerances and competition - would be responsible for regulating adult distributions (e.g., Connell 1961; Dayton 1971; Menge and Sutherland 1976; Paine 1977). Alternatively, planktonic larval supply may be discontinuous and regulated by a combination of biological, physical and chemical mechanisms operating both in the water column (e.g., Prytherch 1929; Coe 1953 and 1956; Underwood and Deleny 1984; Caffey 1985; Gaines et al. 1985) and near or on the seafloor (e.g., Woodin 1976; Eckman 1983; Butman 1987; Mullineaux and Garland 1993; Tamburri et al. 1996).

Water-column processes operating over nine orders of magnitude of time and space scales - from molecular diffusion ( $<$ few mm and < 1 sec; Mann and Lazier 1991) to great gyre circulations (up to ten years and on basin scales) - contribute to variability in distributions of planktonic organisms (Fig. 1.2; Haury et al. 1978; Legendre and Demers 1984; Boicourt 1988; Rothschild 1988; Dickey 1990; Powell 1989; Mann and Lazier 1991). High-frequency (1 sec - $1 \mathrm{~min})$ processes can generate micro-scale (1 mm to $1 \mathrm{~cm}$ ) heterogeneity (Okubo 1984 and 1994; Owen 1989; Davis et al. 1991 and 1992); however, in energetic coastal environments, patchiness at the smallest scales is generally averaged within a population of larvae. Processes operating over extremely long time scales (up to $10 \mathrm{yr}$ ) generally impact biological processes at regional scales and at 
organizational levels higher than the level of a single population (Sinclair 1988; Levin and Huggett 1990; Angel 1991).

In contrast, coarse- $(1$ to $100 \mathrm{~km})$ to meso- $(100-1000 \mathrm{~km})$ scale (as defined by Haury et al. 1978) and shorter time-scale (hours to several weeks) physical processes will likely have the most significant impact on larvae that disperse in the water column on time scales of several weeks to several months (e.g., Boicourt 1988). Examples include wind-driven upwelling and downwelling (e.g., Farrell et al. 1991; Roughgarden et al. 1991; Wing et al. 1995a and 1995b), salinity plumes and fronts (e.g., Le Fèvre 1986), eddies (e.g., Yoder 1983; Flierl and Wroblewski 1985; Flierl and Davis 1993), internal waves (e.g., Shanks 1983), tidal bores (e.g., Pineda 1991), tides (e.g., Levin 1986), waves (e.g., Neumann 1978; Koehl et al. 1993), wind (e.g., Hobbs et al. 1992), and storms (e.g., Barry 1989; McKillup et al. 1995). In addition, biological factors such as vertical migratory behaviors tuned to the diel light/dark cycle (e.g., Forward 1976; Pennington and Emlet 1986; Scrope-Howe and Jones 1986), presence or absence of food and predators (e.g., Mann 1985; Tremblay and Sinclair 1990a and 1990b; Raby et al. 1994), spawning events (e.g., Morgan 1995), growth (e.g., Jørgensen 1981) and natural mortality (e.g., Rumrill 1990) occur simultaneously with physical processes and contribute to heterogeneity in larval distributions on similar scales.

The primary objective of this study was to gain insights into the scales of variability in larval abundance and the physical and biological processes that may be responsible for variations in nearshore larval concentrations of major taxonomic groups. During this study, a time-series zooplankton pump, moored on the inner continental shelf 
off North Carolina, collected hourly larval samples over 3 days in July, 1993. Thus, it is possible to resolve the dominant physical and biological processes occurring at frequencies ranging from 1 cycle every $2 \mathrm{hr}$ (i.e., twice the sampling frequency) to 1 cycle every 3 days (Chatfield 1989; Diggle 1990). These processes include the diel light/dark cycles, semidiurnal tidal cycles, and synoptic wind-driven events. Identifying the controlling processes and the time scales over which they act will aid in the design of future field studies on the causes of larval patch formation, maintenance and transport, and ultimately the coupling between larval supply and larval settlement in the nearshore environment.

\subsection{METHODS}

\subsubsection{Study Location}

The study site was located on the inner shelf off of the Outer Banks at Duck, North Carolina, USA $\left(36^{\circ} 10.895^{\prime} \mathrm{N}\right.$ Latitude, $75^{\circ} 45.068^{\prime} \mathrm{W}$ Longitude; Fig. 1.4), roughly halfway between Cape Henry and Cape Hatteras. The area has a nearly straight coastline with an orientation of $340^{\circ}$. The bathymetry slopes gently off to the east over a $100-\mathrm{km}-$ wide continental shelf. The inner shelf bottom is mostly sand, with occasional hardsubstrates on piers and rock jetties.

In addition to its physical characteristics, this study location was chosen because it was the site of a large interdisciplinary study on larval transport during the following year (August - October 1994; Butman 1994; see section 1.3). The present study was 
conducted, in part, to obtain information on the scales of variability in larval concentration in order to select the sampling scheme for the 1994 field project.

\subsubsection{Sampling Techniques}

A time series of larval concentrations was collected using the Moored Automated Serial Zooplankton Pump (Fig. 1.5; Doherty and Butman 1990; Butman 1994), which has a sample storage mechanism fashioned after the towed Longhurst Hardy Plankton Recorder (Hardy 1936; Longhurst et al. 1966). The entrance region to the intake of this pump is hydrodynamically streamlined to minimize flow disturbances that might otherwise elicit escape responses in the organisms. Seawater is delivered to the pump intake region by the ambient current. Each water sample is first pumped up through a 1-mm mesh prefilter spanning the intake region, and then into a channel where organisms are collected on a strip of $100-\mu \mathrm{m}$ mesh. Thus, organisms larger than $100 \mu \mathrm{m}$ (i.e., the shortest dimension of the $100-\mu \mathrm{m}$ collection mesh) but smaller than $1415 \mu \mathrm{m}$ (i.e., the longest dimension, or diagonal, of the 1-mm mesh prefilter) are retained. Once a discrete sample is collected, it is covered by another strip of $100-\mu \mathrm{m}$ mesh. The two strips, with the sample in between, are wound onto a take-up spool that resides in a nominal $3.7 \%$ formalin bath (buffered with excess $\mathrm{CaCO}_{3}$ ) for long-term storage in situ.

For this nearshore study, the pump sampled at one-hourly intervals over $70 \mathrm{hr}$. Sampling commenced on July 19, 1993 at 18:00 hr and ended on July 22 at 15:00 hr, Local Mean Time (LMT). Volume filtered was 1000 liters during collections at 03:00, 09:00, 15:00, and 21:00 hr; and 500 liters at all other times. The sample volume flux was 
approximately 25 liters $\min ^{-1}$; therefore, it took about 20 and $40 \mathrm{~min}$ to take 500 - and 1000-liter samples, respectively.

The pump was attached to a bottom tripod with the intake located $83 \mathrm{~cm}$ above the bottom. For deployment and recovery, the tripod was lashed to the side members of the 10-m-tall Coastal Research Amphibious Buggy (CRAB; Birkemeier and Mason 1984). The CRAB drove through the surf zone and out to the 8 - $m$ deep study site (approximately $1 \mathrm{~km}$ from shore) where the tripod was unlashed by divers and secured in place with Danforth anchors extending from each leg. Divers scraped fouling organisms and accumulated sediment off the plankton pump surfaces several times during the deployment period.

Instruments maintained by the FRF recorded most of the hydrographic and meteorological data used in this study. Sea surface temperature and salinity were measured daily at the end of the FRF research pier, along the same isobath and within $350 \mathrm{~m}$ horizontally of the plankton sampling location. Water temperature at the depth of the pump intake was measured hourly by a thermistor (sensing changes of $0.8^{\circ} \mathrm{C}$ ) attached to the plankton pump instrument package. Instantaneous measurements of temperature were recorded at the start and end of each plankton sample. Tide data were collected at the end of the FRF pier by a gauge (No. 865-1370) maintained by National Oceanic and Atmospheric Association's National Ocean Service. A Leupold-Stevens digital recording float-type tide gauge collected water-level data every $6 \mathrm{~min}$. Wind speed and direction were obtained from 2-Hz measurements using a Skyvane 
anemometer mounted on top of the FRF, $19.94 \mathrm{~m}$ above sea level and within $725 \mathrm{~m}$ horizontally and along the same isobath of the plankton sampling location.

\subsubsection{Sample Processing and Analysis}

Upon recovery, plankton samples were cut from the mesh and transferred to $80 \%$ ethanol with Rose Bengal stain. Subsequently, samples were washed from the mesh with freshwater, rinsed over a $90-\mu \mathrm{m}$ sieve, then examined using a stereoscopic microscope. Larvae were sorted and identified to major taxonomic group (bivalves, polychaetes, gastropods, bryozoan cyphonautes and barnacle cyprids).

Statistical analyses of the time series were carried out using correlative techniques on data that were lagged in both directions with time steps of $1 \mathrm{hr}$. The series mean was removed from a time series prior to analysis. Decorrelation times - defined by the timepoint where the autocorrelation function crosses the $\mathrm{x}$-axis $(\mathrm{y}=0)$ - provided the number of independent realizations observed in autocorrelated larval concentration or physical time series, and were used to determine statistical significance of cross-correlation analyses. Degrees of freedom $(d f)$ were calculated as follows: $d f=\mathrm{N} \Delta t / \mathrm{DT}$, where $\mathrm{N} \Delta t$ is the total length of the record (70 samples), and DT is the autocorrelation decorrelation time (Emery and Thomson 1997). All reported cross-correlations account for autocorrelation of the lowest-frequency process.

Cross-correlation analyses between pairs of biological time series were used to evaluate whether larval concentrations were coherent (i.e., occurring nearly simultaneously) for all taxa. To illustrate how the frequency of sampling may affect the 
descriptive statistics of this time series, the biological data were subsampled at several time intervals $(3,6,12,24$ and $48 \mathrm{hr}$ ) and summary statistics (i.e., mean, standard deviation, and range) calculated. Possible associations between biological and physical processes were explored using cross-correlations at a variety of time lags between the larval concentration and the physical time series. In the absence of detailed current measurements at the site, the alongshore component of wind velocity was used as a proxy for upwelling/downwelling circulations (see section 2.3). Because a slight linear trend was observed in the water temperature and wind data (see section 2.3), these data sets, as well as the larval concentration time-series data, were de-trended before these specific cross-correlation analyses were done. All statistical tests were done with MATLAB (version 5.2; The MathWorks, Inc.) and SYSTAT (version 7.0; SPSS, Inc) software.

\subsection{RESULTS}

\subsubsection{Oceanographic Setting at the Study Site}

A month's visualization of the daily sea surface temperature and salinity, winds, and tides (Fig. 2.1) provides the oceanographic setting for interpreting patterns in larval abundance. The very striking oscillations in sea surface temperature (in excess of $7^{\circ} \mathrm{C}$ ) and salinity (in excess of 9 parts per thousand, ppt) included periods of cooler, more-saline water alternating with periods of warmer, less-saline water. The more-saline, cool water occurred at the surface near shore when the winds had been blowing toward the north/northeast. When wind speed decreased, or reversed direction, there was a gradual return of warmer, less-saline surface waters near shore. 
(a)

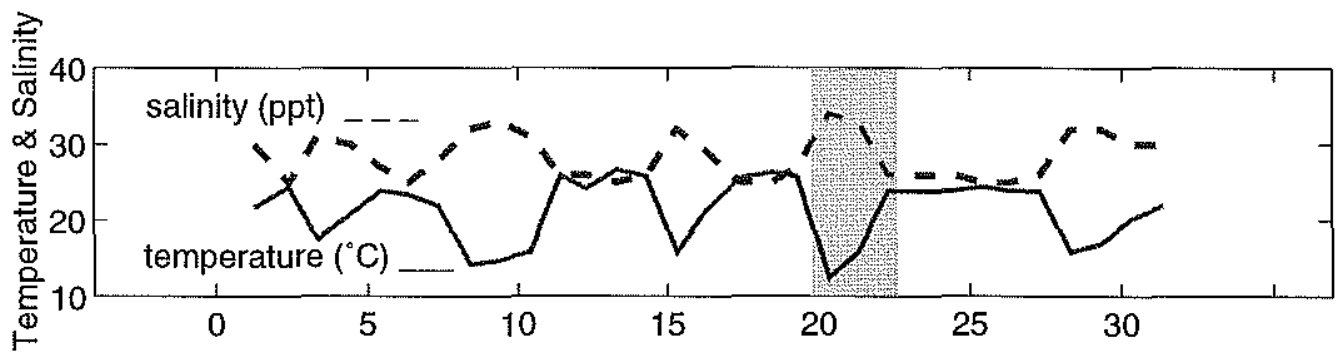

(b)

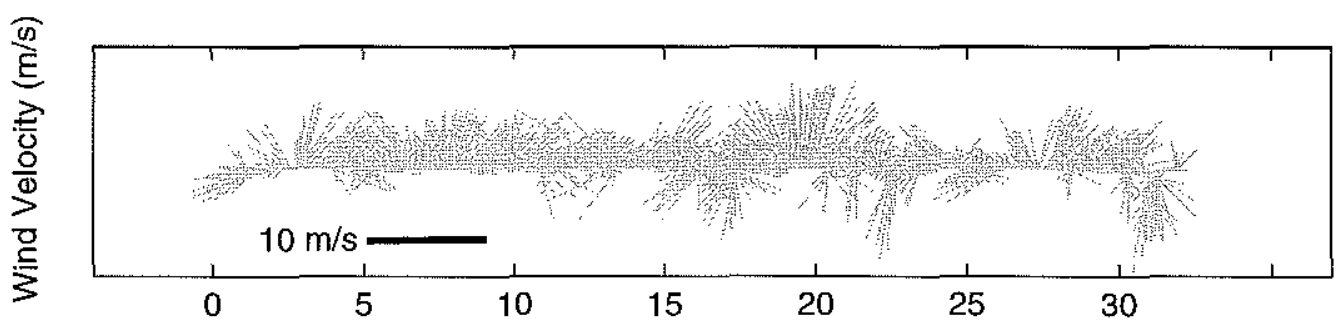

(c)

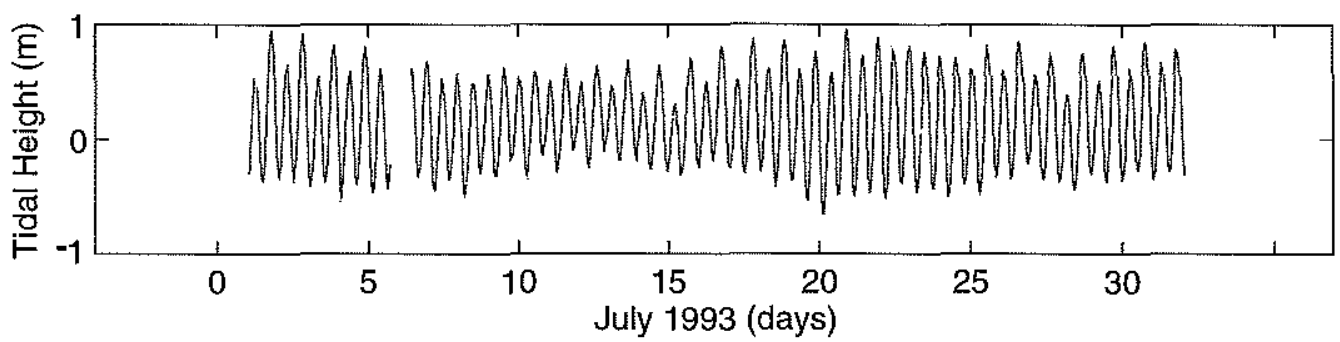

Figure 2.1 Oceanographic setting at the Duck study site during July 1993. All times are given in Local Mean Time (LMT), which was Daylight Savings Time during the study period. (a) Time series of temperature (solid curve) and salinity (dashed curve) of surface waters adjacent to the 8-m site. Shaded area indicates the sampling period for this study. (b) Time series of wind vectors using 34-min-averaged wind velocity data. Vectors point in the direction the wind is blowing (degrees True). Vectors have been rotated by $20^{\circ}$ counterclockwise, such that straight up indicates alongshore wind directed toward $340^{\circ}$ True. The orthogonal component is oriented in a cross-shelf direction, such that a vector to the right indicates an offshore wind. Length of vector indicates wind speed. (c) Time series of tidal height at the end of the FRF pier. 
The coastline at the study site is oriented in a northwesterly/southeasterly direction (Fig 1.5). Thus, winds blowing toward the north/northeast set up classical upwelling flow, where currents move offshore at the surface (i.e., to the right of the wind direction), toward the shore at the bottom, and upwell at the coastal boundary. As the winds diminish or change direction, upwelling relaxes. When winds blow strongly toward the south/southwest, downwelling occurs, bringing in warmer, less-saline water near the coast. These intermittent upwelling and downwelling events, which are common in this region (Boicourt 1973; Birkemeier et al. 1985; Austin and Lentz 1999), are likely responsible for the characteristic temperature-salinity signature observed at the site (Fig. 2.1a).

Low-salinity plumes emanating from the Chesapeake Bay, however, could cause a similar salinity signature near the coast (Fig. 2.1a; Rennie et al. 1999). Buoyancy and wind forcing can drive the plumes past the study region on time scales similar to those of downwelling events (Boicourt 1973; Rennie 1998; Rennie et al. 1999). With limited hydrographic data during this study, it is difficult to separate conclusively these two advective events and determine whether the larval patterns were due to advective movements of concentrated patches (defined as increased concentrations of larvae within a given area relative to lower background concentrations) in a cross-shelf or an alongshore direction. Detailed hydrographic measurements made at the same site the following summer during the Coastal Ocean Processes project (CoOP94; Butman 1994; Alessi et al. 1996; Austin 1998; Fedderson et al. 1998; Lentz et al. 1999; Rennie et al. 
1999) provide some insight into the potential roles of cross-shelf versus alongshore flows. Data from CoOP94 indicate that a temperature-salinity signature like the one observed during July 1993 is likely due to cross-shelf advection and movement of the thermocline because water masses advected alongshore displayed primarily salinity anomalies (salinities $<28 \mathrm{psu}$ ) that were rarely accompanied by temperature differences as large (Austin 1998, 1999; Rennie 1998). Furthermore, the precipitous drop in salinity was usually not coincident with a change in wind direction; the arrival of salinity anomalies at the study site usually lagged by several days the onset of downwelling at the study region (Rennie 1998; Rennie et al. 1999).

At the start of the sampling period, upwelling conditions existed and relatively cool water masses were near the pump and sea surface (Fig. 2.2a). Downwellingfavorable winds (Fig. 2.2b) occurred in short pulses during the first two days, but they were insufficient to downwell the thermocline to the depth of the pump until midday on July 21 . The dramatic temperature increase at $7 \mathrm{~m}$ depth (i.e., just after noon on July 21 ; Fig. 2.2a) is likely due to the passage of the downwelled thermocline.

Semi-diurnal tides are characteristic of this inner-shelf site (Fig. 2.1c), producing a weak M2 tidal flow of less than $5 \mathrm{~cm} \mathrm{sec}^{-1}$ and a mean amplitude of $0.5 \mathrm{~m}$ (Alessi et al. 1996, Lentz et al. [in prep], Rennie et al. 1999). Thus, tidal flow would not be capable of producing appreciable net transport. For example, as the tide rises, water is moved in one direction (shoreward) for approximately $6 \mathrm{hr}$, leading to a displacement of $<1 \mathrm{~km}$; but, as the tide falls, the water would be displaced an approximately equal distance in the opposite direction. 
(a)

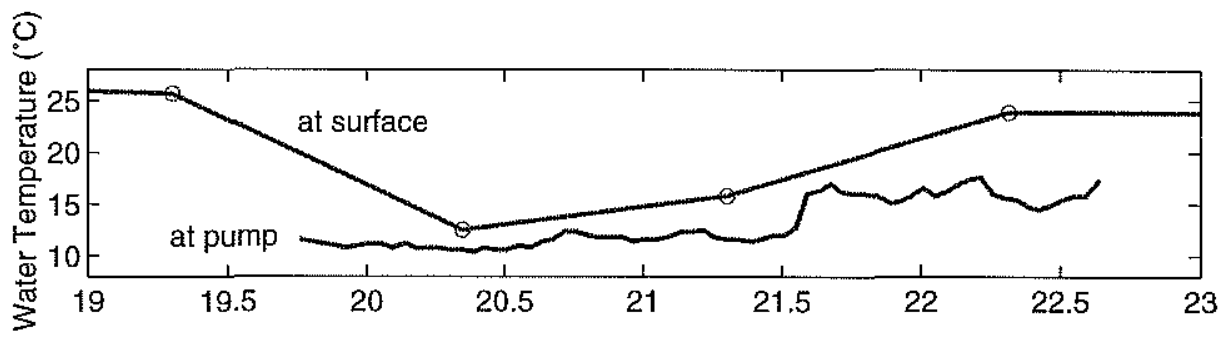

(b)

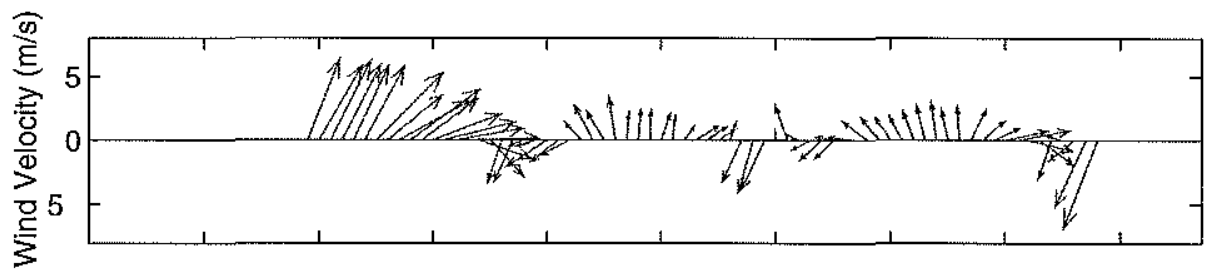

(c)

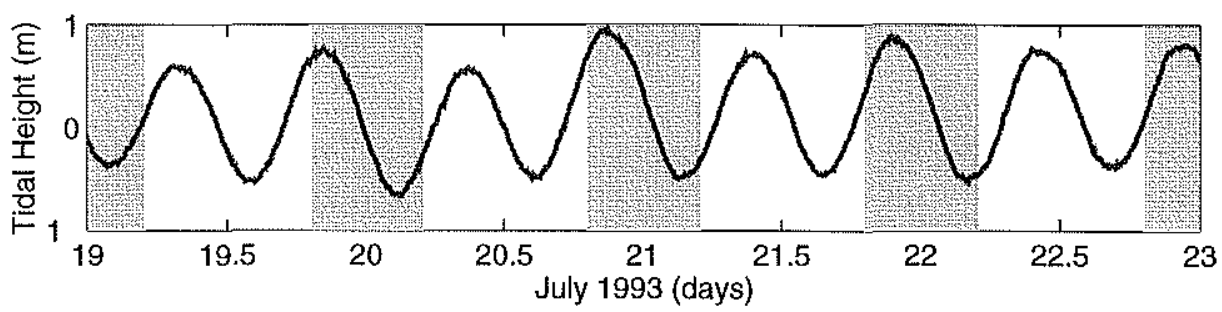

Fig. 2.2 Oceanographic setting at the Duck study site during July 19-22, 1993. (a) Time series of water temperature at the surface and near the depth of the pump intake $(83 \mathrm{~cm}$ above the bottom). The length of the pump water temperature time series indicates the larval sampling period. (b) Time series of hourly-averaged wind vectors (using $2-\mathrm{Hz}$ data) Rotation of wind vectors is explained in Fig. 2.1b. (c) Time series of tidal height at the end of the FRF pier. Surface heat flux (Watts $/ \mathrm{m}^{\wedge} 2$ ) was estimated and used as a proxy for solar radiation. Shaded periods correspond to night times when the surface heat flux was close to 0 Watts $/ \mathrm{m}^{\wedge} 2$. 
Waves, and currents were not characterized during the 1993 field study, but detailed measurements and characterization of these variables were made during the following summer. Waves and currents are the dominant physical processes responsible for transport in this nearshore region (Fedderson et al. 1998; Lentz et al. 1999). Alongshore currents are typically 10 to $30 \mathrm{~cm} \mathrm{sec}^{-1}$, but may increase to $80 \mathrm{~cm} \mathrm{sec}^{-1}$ near shore during downwelling conditions. Cross-shelf flows are typically of order $5 \mathrm{~cm} \mathrm{sec}^{-1}$, and may increase to $20 \mathrm{~cm} \mathrm{sec}^{-1}$ during upwelling conditions (Alessi et al. 1996, Lentz et al. 1999, Rennie et al. 1999). Waves breaking near shore can force flows up to $140 \mathrm{~cm}$ $\sec ^{-1}$ in the alongshore direction (Fedderson et al. 1998).

\subsubsection{Patterns in Larval Concentration and Correspondence with Physical Data}

The larval concentration time series (Fig. 2.3) showed high temporal variability for all taxa. Ranges in larval concentration were $0-516 \mathrm{~m}^{-3}$ for bivalves, $6-414 \mathrm{~m}^{-3}$ for gastropods, $0-668 \mathrm{~m}^{-3}$ for polychaetes, $5-746 \mathrm{~m}^{-3}$ for barnacle cyprids, and $0-86 \mathrm{~m}^{-3}$ for bryozoan cyphonautes. In most cases, the maximal concentrations represented a change of more than two orders of magnitude over the course of just several hours. A substantial maximal and one submaximal peak concentration occurred for each group, with low concentrations, of order $0-10{ }^{\prime} \mathrm{s} \mathrm{m}^{-3}$ in most cases, between these two peaks. A potential sampling artifact may have slightly obscured the true maximum and minimum concentrations. That is, during the relatively long sampling intervals of 20 and $40 \mathrm{~min}$, the pump may have collected larvae wholly within a patch (observed maximum was 
(a)

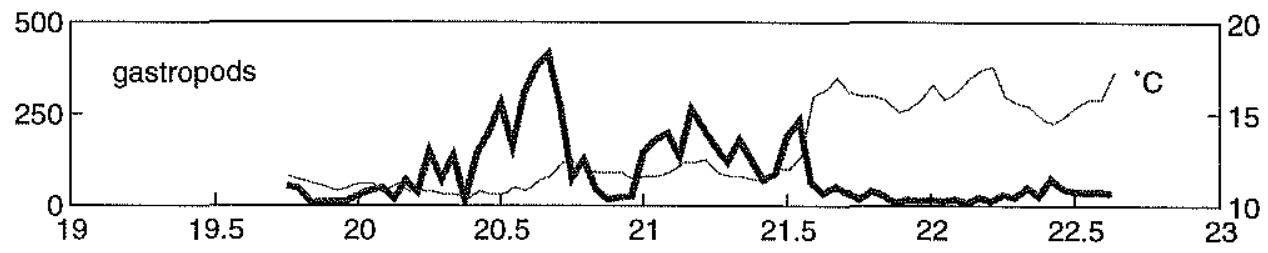

(b)

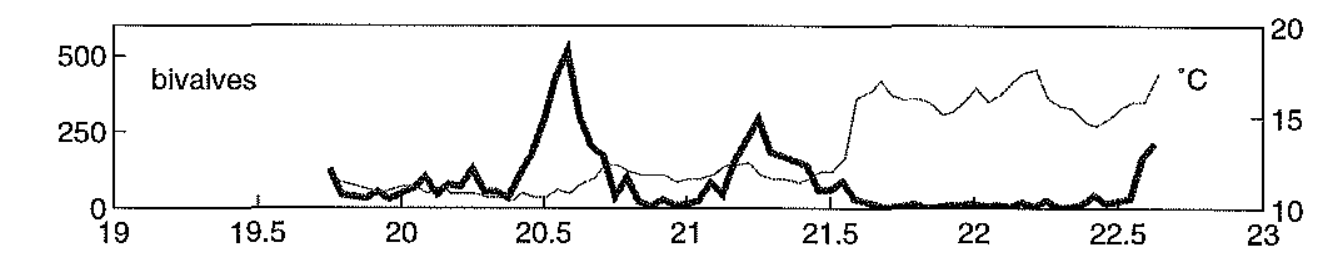

(c)

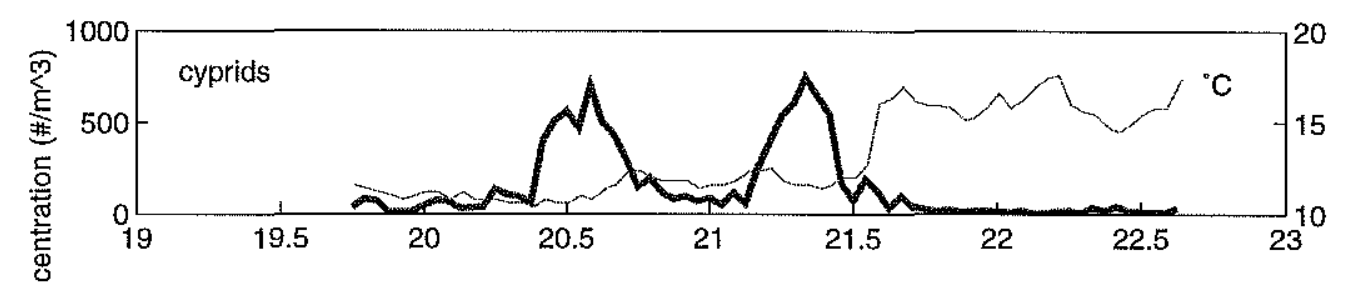

(d)

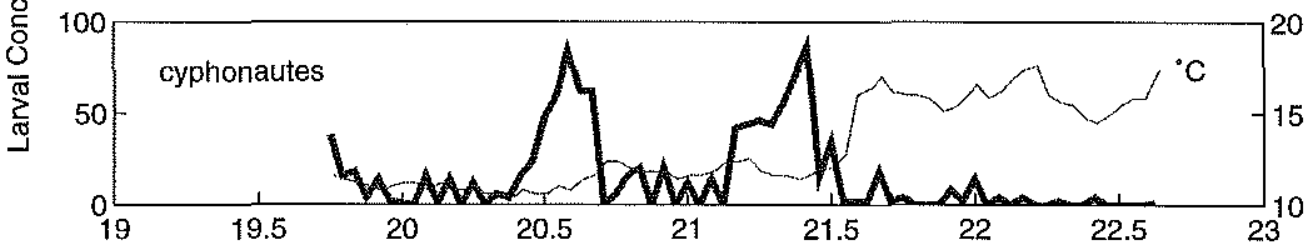

(e)

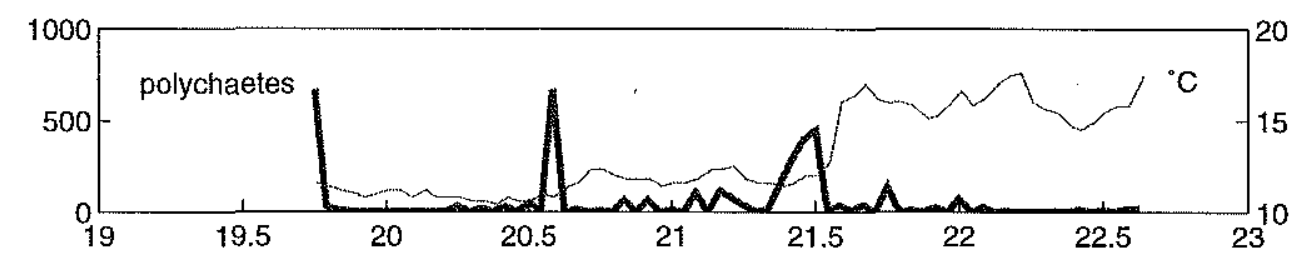

(f)

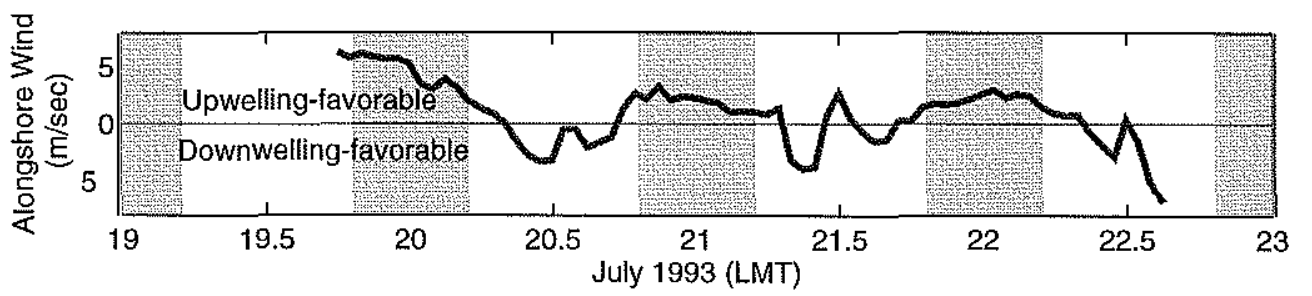

Figure 2.3 Time series of larval concentrations (a-e; bold lines) for five taxa (gastropods, bivalves, barnacle cyprids, bryozoan cyphonautes and polychaetes) with water temperature near the pump intake (thin lines) superimposed, and alongshore component of wind velocity (f). Three plankton samples ( $00: 00 \mathrm{hr}$ on July 20 and 05:00 and 09:00 hr on July 21) were damaged during recovery and processing; interpolated values were used in these three cases. Positive values of alongshore winds are upwelling-favorable, i.e., blowing toward the north/northeast, and negative values are downwellingfavorable, i.e., blowing alongshore toward the south/southwest. Nighttime is shaded (see Fig. 2.2c for explanation). 
approximately "true"), entirely outside of a patch (observed minimum was approximately "true"), or in some cases, partly within and partly outside of a patch (maximum and minimum may have been obscured).

Peaks in larval concentration were remarkably distinct, even though larvae were grouped as major taxa and not enumerated as species. Furthermore, all of the taxonomic groups peaked at about the same times (Fig. 2.3 and 2.4), indicating that they may have been transported synchronously as a single patch. Taxonomic groups were represented by a variety of both hard-substrate and soft-substrate organisms. The highest peak in abundance was in polychaetes and cyprids, followed by bivalves and gastropods. Bryozoan cyphonautes had the lowest peak abundance.

Intrusion of warmer, less-saline water into the study region corresponded with decreases in the local abundances (Fig. 2.3). The maximal and submaximal peaks in larval concentration occurred, however, during a period when cool water was near the pump (July 19, 12:00 hr to July 21, 12:00 hr, LMT). In all groups except bivalves, no peaks were associated with the warmer water masses (July $21,14: 00 \mathrm{hr}$ to July 22, 15:00 hr, LMT). A slight increase in bivalve concentration, represented by two samples, occurred at the end of the time series when warm water was near the pump.

There were significant cross-correlations (Fig. 2.5) between the larval time series and the alongshore component of wind velocity, which serves as a proxy for upwelling/downwelling circulation events. For bivalves, there was a significant negative correlation $(r=-0.579, \mathrm{p}<0.05)$ at 0 lag, indicating that over short time scales, larval 


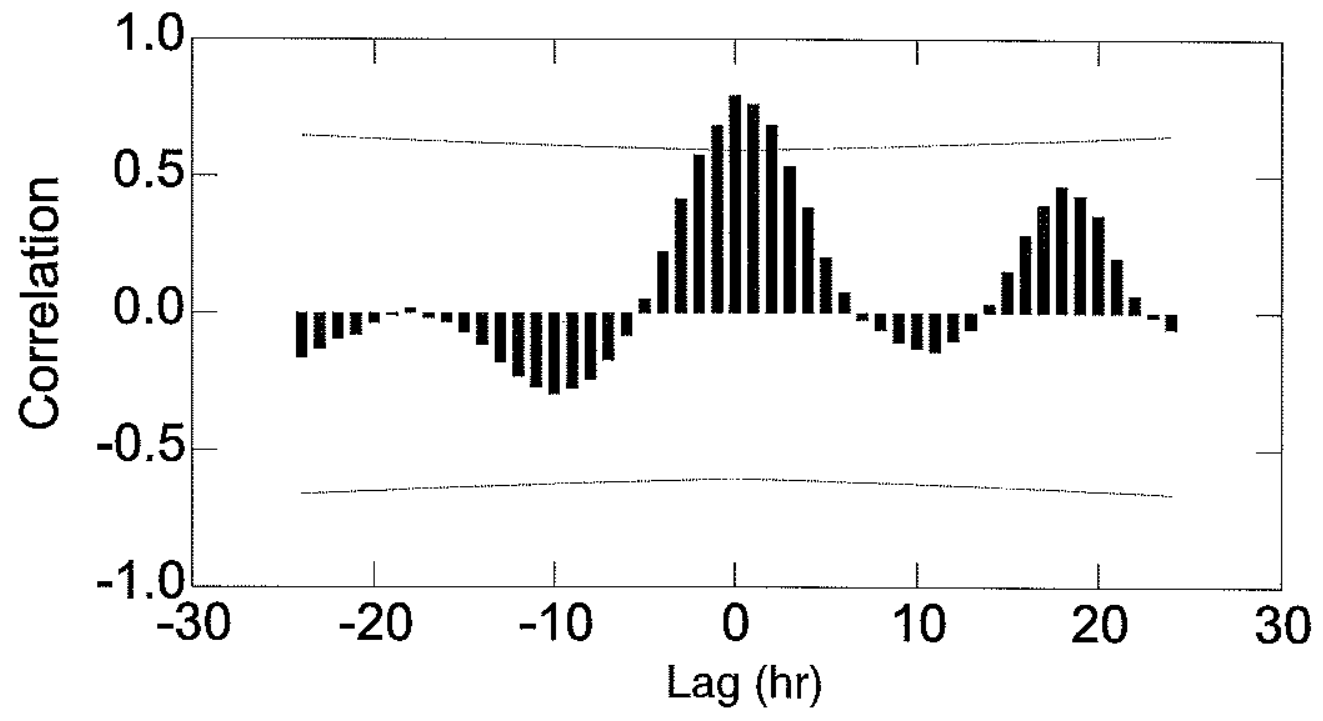

Figure 2.4 Cross-correlations between bivalve and barnacle cyprid concentrations $(r=0.793, p<0.01)$. The length of each bar indicates the size of the correlation at each hourly lag, and the dotted horizontal curves are the $99 \%$ confidence intervals accounting for autocorrelation in the series. Positive lags relate larval bivalve concentration to subsequent values of barnacle cyprid concentration. All other combinations (except those involving polychaetes) were significantly correlated at the $95 \%$ confidence level, or higher. 


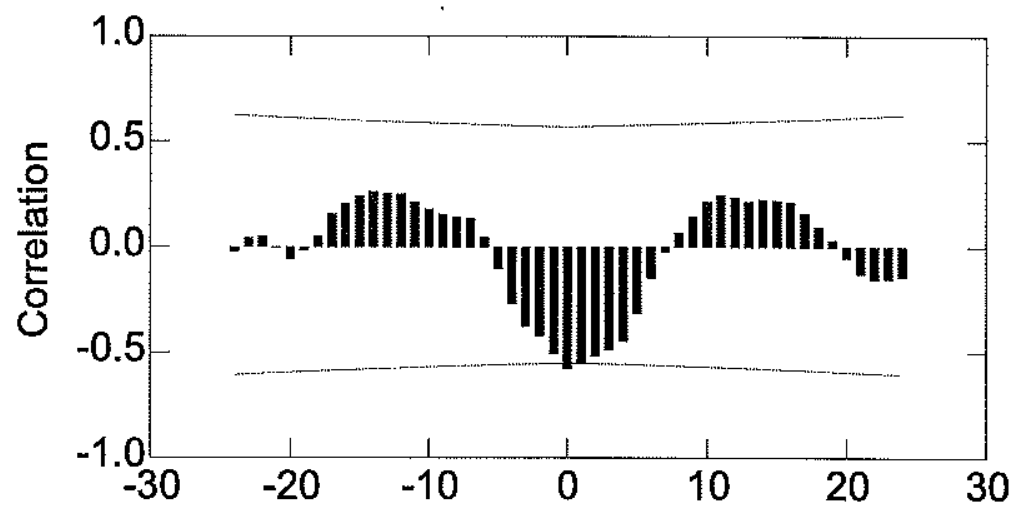

Figure 2.5 Cross-correlation between alongshore component of wind velocity and bivalve concentration time series $(r=-0.579, p<0.05)$. See Fig. 2.4 for explanation. A linear trend was removed from the larval concentration and wind velocity time series before cross-correlation analyses were done. All other groups (except polychaetes and cyphonautes) were negatively correlated at the $95 \%$ confidence level, or higher. 
concentration increased during downwelling-favorable wind events. In fact, maximal and submaximal peaks in larval concentration occurred during the two instances when upwelling relaxed and short bursts of downwelling-favorable winds followed (Fig. 2.3f).

\subsubsection{Scale of Temporal Variability and Statistical Effects of Sampling Frequency}

Decorrelation times - quantified from autocorrelation analyses - were approximately 5 $\mathrm{hr}$ in bivalves (Fig. 2.6a), $6 \mathrm{hr}$ in barnacle cyprids and bryozoan cyphonautes, and $7 \mathrm{hr}$ in gastropods. This decorrelation time scale identifies the period of maximum variability and determines the sampling frequency required to capture the dominant temporal variability. Thus, it can be used to guide future sampling efforts in similar coastal regimes. For larval groups with broad peaks in concentration, as seen in bivalves, barnacle cyprids, gastropods and bryozoan cyphonautes, one sample collected every 2.5 $3.5 \mathrm{hr}$ (i.e., half the decorrelation time) would be required to preserve variability and trend. Because autocorrelations of polychaete larvae were not significant (Fig. 2.6b) and peaks in concentration were narrow and sharp and persisted for less than $1 \mathrm{hr}$ (Fig. 2.3e), more frequent sampling likely is required for this group. Alternatively, the dominant scale of variability in polychaete concentrations may be determined by episodic events or other processes occurring on time scales longer than 3 days, rather than processes occurring on scales shorter than $2 \mathrm{hr}$. 
(a)

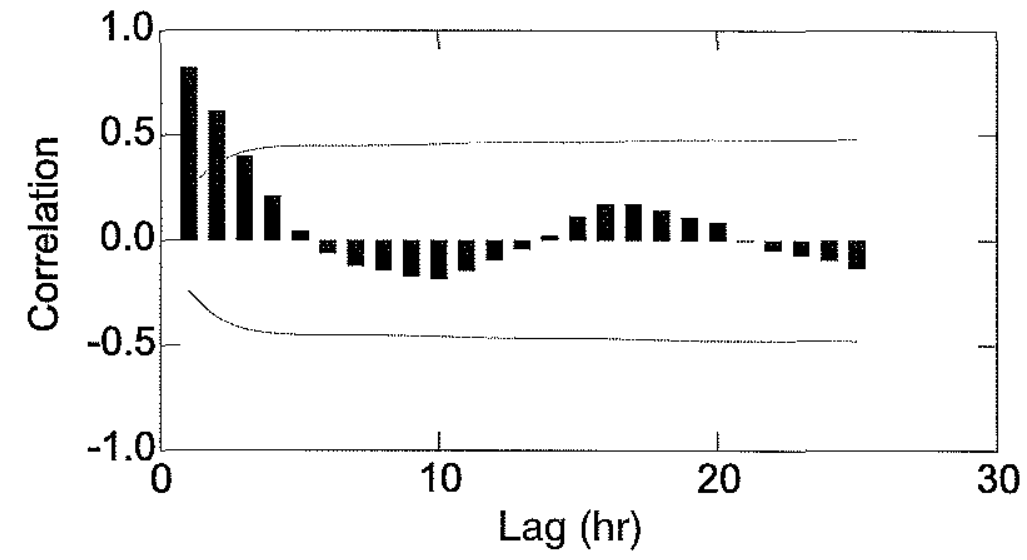

(b)

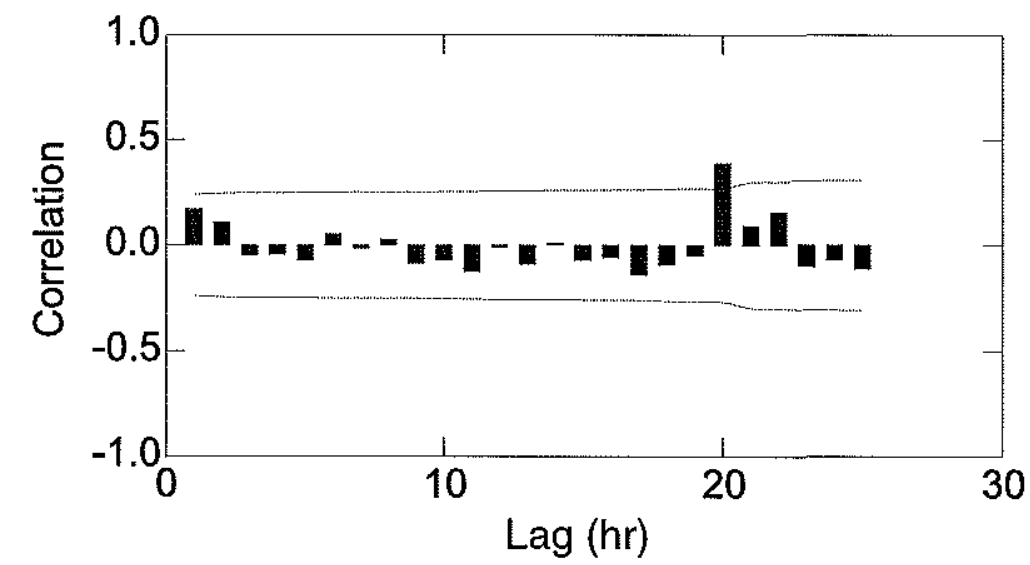

Figure 2.6 Autocorrelations for time series of bivalve concentrations (a), and polychaete concentrations (b). The length of each bar indicates the size of the correlation at each hourly lag, and the dotted horizontal curves give $95 \%$ confidence intervals. The time point where the autocorrelation function crosses the $\mathrm{x}$-axis indicates the decorrelation time scale of the series. The decorrelation time was $5 \mathrm{hr}$ for bivalves and could not be determined for polychaete larvae (which were not significantly autocorrelated). 
Table 2.1 Summary statistics for the larval concentration time series (hourly samples, first column) and the same data subsampled at 3,6,12, 24, and 48-hr intervals. Values for mean, standard deviation, minimum, maximum, and range are reported as number of larvae per $\mathrm{m}^{3}$.

Group

Statistic
Sampling Interval

1-hr 3-hr 6-hr 12-hr 24-hr 48-hr

\section{Bivalves}

mean

standard deviation

minimum

maximum

range

\section{Polychaetes}

mean

standard deviation

minimum

maximum

range

\section{Bryozoans}

mean

standard deviation

minimum

maximum

range

\section{Barnacle Cyprids}

mean

standard deviation

minimum

maximum

range

\section{Gastropods}

mean

standard deviation

minimum

maximum

range

$\begin{array}{llllll}83.1 & 80.7 & 88.8 & 103.0 & 57.3 & 67.0 \\ 102.0 & 97.8 & 102.4 & 106.3 & 63.3 & 86.3 \\ 0 & 3 & 6 & 6 & 6 & 6 \\ 516 & 300 & 292 & 292 & 128 & 128 \\ 516 & 297 & 286 & 286 & 122 & 122\end{array}$

$\begin{array}{llllll}53.9 & 69.2 & 122.8 & 146.7 & 270.0 & 401.00 \\ 133.6 & 159.3 & 212.0 & 259.9 & 350.4 & 377.6 \\ 0 & 0 & 0 & 0 & 8 & 134 \\ 668 & 668 & 668 & 668 & 668 & 668 \\ 668 & 668 & 668 & 668 & 660 & 534\end{array}$

$\begin{array}{llllll}15.7 & 15.0 & 17.9 & 17.7 & 16.0 & 21.0 \\ 22.2 & 21.9 & 18.4 & 19.4 & 19.1 & 24.0 \\ 0 & 0 & 0 & 0 & 4 & 4 \\ 86 & 71 & 48 & 46 & 38 & 38 \\ 86 & 71 & 48 & 46 & 34 & 34\end{array}$

$\begin{array}{llllll}152.5 & 132.9 & 141.0 & 149.3 & 70.0 & 31.0 \\ 201.0 & 200.3 & 195.6 & 195.9 & 67.7 & 7.1 \\ 5 & 5 & 12 & 18 & 26 & 26 \\ 746 & 647 & 564 & 532 & 148 & 36 \\ 741 & 642 & 552 & 514 & 122 & 10\end{array}$

$\begin{array}{llllll}90.3 & 83.1 & 98.8 & 81.0 & 48.7 & 35.0 \\ 94.4 & 96.0 & 85.0 & 61.0 & 30.4 & 26.9 \\ 6 & 20 & 20 & 20 & 20 & 20 \\ 414 & 378 & 278 & 162 & 76 & 54 \\ 408 & 372 & 262 & 146 & 60 & 38\end{array}$


Sampling interval can alias the patterns of a time series displaying short-term fluctuations (Table 2.1; Taggart and Frank 1990; Taylor et al. 1993; Taylor and Howes 1994). Temporal variability is reduced by subsampling the data set at regular intervals. For all taxonomic groups except polychaetes, calculated means for all subsampled data were lower, but remained within one standard deviation of the mean calculated from hourly data. For polychaetes the effect was more pronounced: calculated means for all subsampled data fell within three standard deviations of the mean calculated from hourly data. In all groups, the range in larval concentration decreased as sampling frequency decreased, and in two cases (barnacle cyprids and gastropods), the change exceeded an order of magnitude. Moreover, for these time series, mean concentrations change significantly depending upon the starting time for averaging. For example, larval samples that were collected every $24 \mathrm{hr}$ starting at midnight would have a much lower mean than a series collected every $24 \mathrm{hr}$ beginning at noon due to the peaks in abundance occurring near noon.

\subsection{DISCUSSION AND CONCLUSIONS}

Patterns of Temporal Variation: High variability in larval concentrations of bivalves, gastropods, polychaetes, barnacles (cyprids) and bryozoans (cyphonautes) was observed at this near-shore site. One goal of this study was to gain insight into the sampling scheme required to capture the dominant temporal signal in larval concentrations for similar coastal habitats. Sampling frequency depends, in part, on the decorrelation time 
of the targeted larval group — that is, lower-frequency sampling is required for groups with broader peaks in abundance (i.e., longer decorrelation times). For all taxonomic groups except polychaetes, sampling at approximately 3 -hr intervals (i.e., half the decorrelation time) would have captured the majority of the variability for this time and place. Sampling the data at lower frequencies (i.e., at intervals $>6 \mathrm{hr}$ ) reduced the range in larval concentration, yet the means remained within one standard deviation of the mean calculated from hourly data. With lower-frequency sampling, patterns were aliased by the short-term fluctuations in larval concentration.

Undoubtedly, different oceanic and coastal regions, depths, and seasons will have different physical processes affecting larval variability. Moreover, it is likely that variability in larval concentration will be a function of larval age and species, with different forces having a dominant effect at different life history stages, and species displaying specific behaviors. The biological time series presented here indicate that all larval groups were being transported by a similar mechanism(s) at this near-shore site because decorrelation times were similar and variations in larval concentration were coherent among the diverse groups. This result is tentative, however, because the length of the time series is short, and because other studies have shown that species- or stagespecific behavioral differences in planktonic larvae could explain gradients in adult distributions (e.g., Grosberg 1982; Gaines et al. 1985; Caffey 1985).

Time series of larval concentration provide insights into the spatial characteristics of larval distributions. For example, peaks in larval concentration showed similar patterns when grouped by major taxa or when combined as total individual larvae; that is, 
the time series were coherent. This result suggests that physical forces or ubiquitous larval characteristics maintained diverse larval groups within a single patch despite other concurrent physical or biological diffusive processes such as species- or taxon-specific behaviors. Moreover, amplitudes of the maximal and submaximal peaks in larval concentration were similar within individual taxonomic groups, suggesting patches may have a characteristic density or may have experienced minimal mixing or dilution of larvae over time. Although it appears that all taxonomic groups were exhibiting strikingly similar temporal variations in abundance, the time interval between the two major peaks was slightly different for each taxon (i.e., they were slightly phase-shifted). Peaks were separated by $12 \mathrm{hr}$ for gastropods, $16 \mathrm{hr}$ for bivalves, $18 \mathrm{hr}$ for barnacle cyprids, $20 \mathrm{hr}$ for bryozoan cyphonautes, and $22 \mathrm{hr}$ for polychaete larvae (Fig. 2.3). Moreover, the width of the peaks was different in the various larval groups. Thus, there appeared to be a spatial gradient of larval groups within a larger patch.

The biological time series generated in this study was sufficiently long to show a detectable signal with an emerging scale, yet too short to enable definitive analyses of the physical processes responsible for generating the observed variations. Correspondences between the time series of larval concentration and water temperature, and between larval concentration and wind velocity, are intriguing. Yet, without detailed information on current velocity, and because biological sampling was limited to a single location and depth over a 70-hr period, it is impossible to establish definitive relationships between biological and physical variables. Rather, these time series show detectable signals for 
major taxonomic groups of larvae that may be explained by several alternative hypotheses.

At least two scenarios are consistent with the observed variations in abundance. The first is a physically motivated explanation, involving patches larvae being shaped and moved primarily by physical forces operating at meso-scales. The alternative scenario primarily involves an active behavioral response of the larvae to an environmental cue on finer scales.

Wind-Driven Cross-Shelf Transport: In the first scenario, temporal patterns represent movements of larvae that result primarily from physical forcing. Larvae may have arrived at the near-bottom pump location by vertical mixing, by advection in cross-shelf (which have a strong vertical component down-slope near the coast) or alongshore currents, or by passively settling to the bottom as upward water velocities associated with upwelling conditions diminish. In the latter case, the heaviest and most calcified larval types - bivalves, gastropods, and barnacle cyprids - would be the first to settle to the bottom. Vertical mixing is unlikely to have caused the observed peaks in concentration because increases in water temperature were not observed at the near-bottom pump during the two short bursts of downwelling-favorable winds; that is, the water column remained thermally stratified. Passive transport in alongshore flows is unlikely to have caused the observed variations because larvae were associated with specific water temperatures, and water-temperature variations of the magnitude observed during this study were likely due to cross-shelf advection of the thermocline (see section 2.3.1). 
Figure 2.7 Diagrammatic representation of a hypothesized physical mechanism for generating observed variations in larval concentration. A single patch is considered in this scenario. Scales of depth and distance offshore were chosen for illustrative purposes and do not necessarily reflect the exact vertical and horizontal scales of thermal variability at the study site. $(a)$ The water column is thermally stratified. Few or no larvae are sampled by pump because larvae are being moved and concentrated elsewhere by upwelling flows. Temperature of cool, upwelling surface waters begins to match the temperature of water near the pump intake. (b) Upwelling relaxes and a larval patch is advected to the pump location, but current strength (or duration) is insufficient to advect the downwelling front to the pump. (c) Downwelling-favorable winds diminish or change direction and upwelling resumes. Larvae return to surface waters. (d) Upwelling relaxes a second time and advects the same patch of larvae past the near-bottom pump. Subsequently, the downwelling thermal front intersects the bottom near the pump as nearshore waters are advected offshore. For the rest of the time period, upwelling winds are weak and insufficient to cause cooler water masses to move back into the study region. 

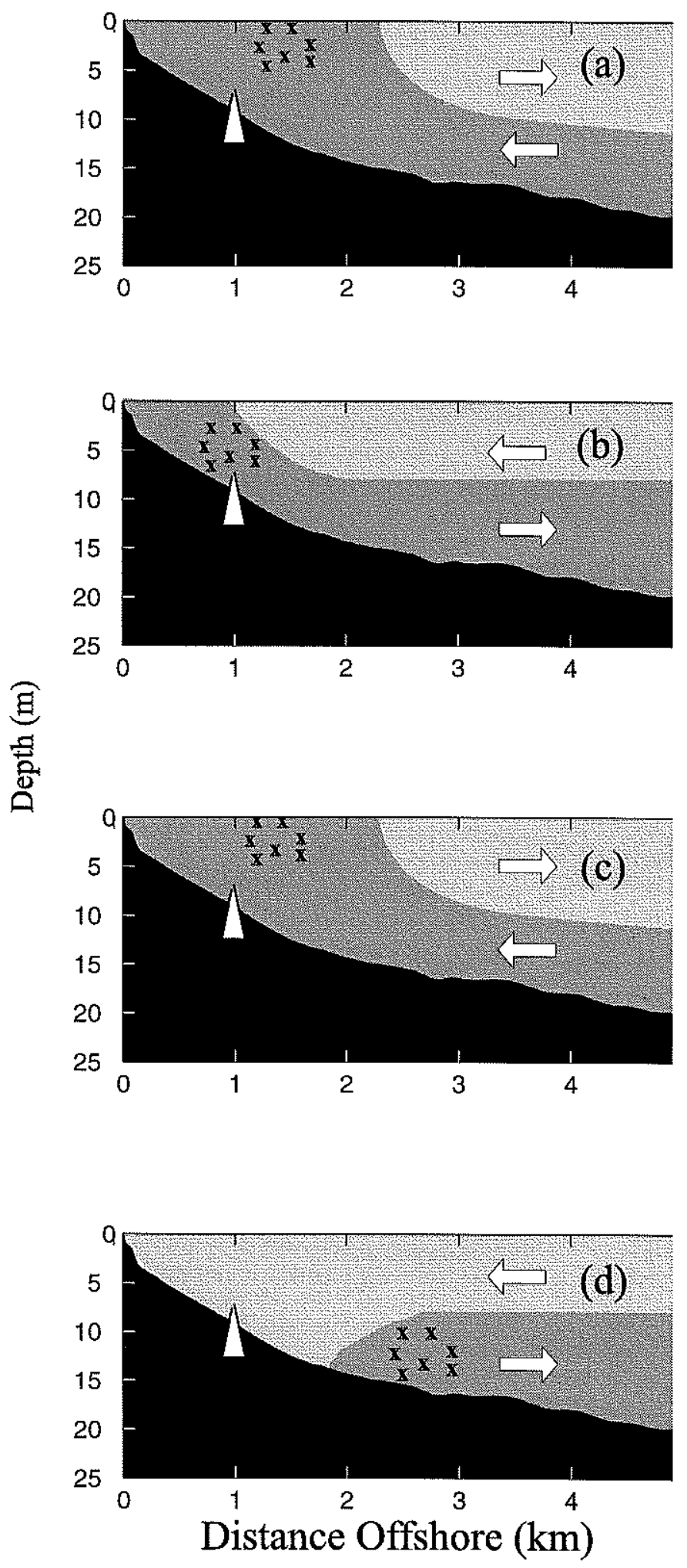
Of the physically motivated scenarios, cross-shelf advection of larval patches due to wind-driven upwelling and downwelling is the explanation most consistent with the larval data and knowledge of the physical dynamics at the study site (Fig. 2.7). Peaks in larval concentration occurred when the cooler, more-saline water was near the pump, suggesting that larvae tracked with water masses of a specific temperature and were transported onshore and concentrated into discrete patches (mechanism detailed in Epstein 1995) during upwelling conditions over long time scales. Subsequently, larvae may have been advected shoreward, then down-slope past the pump, upon relaxation from upwelling or the onset of downwelling-favorable winds (Fig 2.3 and 2.7). The association of larvae with cooler water, the coherence in temporal variations among diverse larval groups, and the cross-correlations between larval concentration and the alongshore component of wind velocity support this scenario of transport in wind-driven upwelling and downwelling flows. Thus, relaxation from upwelling or subsequent downwelling conditions would move larvae to, or provide conditions under which larvae passively settle to, a near-bottom location. Patterns of settlement and recruitment reflective of this process have been described (e.g., Roughgarden et al. 1991; Farrell et al. 1991; Wing et al. 1995a).

Diel Vertical Migrations: In contrast, an alternative scenario primarily involves an active behavioral response of the larvae. In all five larval groups, the first peak in nearbottom concentration occurred shortly after local noon; and ,thus, larvae may have actively moved down from surface waters during periods of peak solar radiation. Such a 
movement is consistent with diel vertical migration behavior (i.e., nocturnal ascent; Forward 1976). The second set of peaks, however, were not only staggered from one another, but also occurred well before noon in all groups except polychaetes, which peaked near noon. Peaks in larval concentration that are not separated by $24 \mathrm{hr}$ are generally inconsistent with diel vertical migration patterns (Forward 1976). Furthermore, there were no peaks in concentration near noon on the last day of the time series (July 22). However, a thermistor attached to the plankton pump indicated that the downwelled thermocline, with a gradient of approximately $5^{\circ} \mathrm{C}$, passed by the site sometime between 13:00 and 14:00 hr LMT on the second day (Fig. 2.3). This advective perturbation may have disrupted temporarily natural vertical migrations exhibited by larvae. Downwelling water may have displaced larvae to the bottom prematurely, relative to a diel cycle, by overcoming their natural upward swimming behavior. Thus, a combination of physical forces and behavioral repertoires may have been responsible for creating the observed temporal patterns.

Predictions and Conclusions: Although it is impossible to establish definitive relationships between larval variability and forcing mechanisms with such a short time series collected at a single site and without detailed hydrodynamic information, certain predictions can be made based on these data. Near-bottom concentrations were highest during periods following the relaxation of upwelling and the onset of downwellingfavorable winds. Therefore, periods of strong settlement and recruitment should coincide with similar relaxation and downwelling conditions along this coast. Regardless of 
whether larvae arrived at the bottom through active swimming or by passive physical transport, their arrival identifies a period during which metamorphically competent larvae could recruit into benthic communities.

The strictly empirical approach outlined in this paper represents an initial foray into interpretations of temporal variability in larval abundance. The results were used to generate hypotheses of the distinct mechanisms responsible for generating the observed variations, but longer time series and greater spatial coverage are required to evaluate alternative scenarios. 


\subsection{ACKNOWLEGEMENTS}

I thank Jay Sisson, Craig Lewis, Bill Birkemeier, Mike Leffler, Ray Townsend, and Gene Bichner for assistance with the tripod deployments. Ken Doherty, Ken Fairhurst, Steve Longworth and Jay Sisson provided engineering advice and assistance with the pumps. The Field Research Facility at Duck, NC, recorded hydrographic data used in this study; permission to use these data is appreciated. Cliff Baron at the FRF was an invaluable source for the hydrographic data presented here. Vicke Starczak commented on an earlier draft of this paper and Steve Lentz aided with interpretation of the physical oceanographic data.

This research was supported by NSF's Coastal Ocean Processes (CoOP) Program (OCE91-23514 and OCE92-21615 to Cheryl Ann Butman, and OCE96-33025 to Steven J. Lentz and Cheryl Ann Butman). 


\subsection{LITERATURE CITED:}

Alessi CS, Lentz SJ, Austin J (1996). Coastal Ocean Processes Inner Shelf Study: Coastal and moored physical oceanographic instruments. Woods Hole Oceanogr. Instn. Tech. Rpt. WHOI-96-06: 1-142

Angel MV (1991). Variations in time and space: Is biogeography relevant to studies of long-time scale change? J. mar. biol. Ass. UK 71: 191-206

Austin JA (1998). Wind-driven circulation on a shallow, stratified shelf. Ph.D. Dissertation, Massachusetts Institute of Technology / Woods Hole Oceanographic Institution, Woods Hole, MA

Austin JA (1999). The role of the alongshore wind stress in the heat budget of the North Carolina inner shelf. J. Geophys. Res. 104: 18187-18203.

Austin JA, Lentz SJ (1999). The relationship between synoptic weather systems and meteorological forcing on the North Carolina inner shelf. J. Geophys. Res. 104: 1815918185.

Barry JP (1989). Reproductive response of a marine annelid to winter storms: An analog to fire adaptation in plants? Mar. Ecol. Prog. Ser. 54: 99-107.

Birkemeier WA, Mason C (1984). The CRAB: A unique nearshore surveying vehicle. J. Survey Eng, American Society of Civil Engineers, Vol. 110, No. 1

Birkemeier WA, Miller HC, Wilhelm SD, DeWall AE, Gorbics CS (1985). User's guide to the Coastal Engineering Research Center's (CERC's) Field Research Facility. Instruction Report CERC-85-1, May 1985. Coastal Engineering Research Center, US Army Engineer Waterways Experiment Station, Vicksburg, MS

Boicourt WC (1973). The circulation of water on the continental shelf from Chesapeake Bay to Cape Hatteras. Ph.D. Thesis, The Johns Hopkins University, Baltimore, MD

Boicourt WC (1988). Recruitment dependence on planktonic transport in coastal waters. In: B. J. Rothschild (ed), Toward a theory on biological-physical interactions in the world ocean. Kluwer Academic Publishers, Boston, MA, p. 183-202

Butman CA (1987). Larval settlement of soft-sediment invertebrates: The spatial scales of pattern explained by active habitat selection and the emerging rôle of hydrodynamical processes. Oceanogr. mar. Biol. A. Rev. 25: 113-165 
Butman CA (1994). CoOP: Coastal Ocean Processes Study, interdisciplinary approach, new technology to determine coupled biological, physical, geological processes affecting larval transport on inner shelf. Sea Tech. 35: 44-49

Caffey HM (1985). Spatial and temporal variation in settlement and recruitment of intertidal barnacles. Ecol. Monogr. 55: 331-332

Chatfield C (1989). The analysis of time series: An introduction. Chapman and Hall, NY

Coe WR (1953). Resurgent populations of littoral marine invertebrates and their dependence on ocean currents and tidal currents. Ecology 34: 225-229

Coe WR (1956). Fluctuations in populations of littoral marine invertebrates. J. mar. Res. 15: 212-232

Connell JH (1961). Effects of competition, predation by Thais lapillus, and other factors on natural populations of the barnacle, Balanus balanoides. Ecol. Monogr. 31: 61-104

Davis CS, Flierl GR, Wiebe PH, Franks PJS (1991). Micropatchiness, turbulence and recruitment in plankton. J. mar. Res. 49: 109-151

Davis CS, Gallager SM, Solow AR (1992). Microaggregations of oceanic plankton observed by towed video microscopy. Science $257: 230-232$

Dayton PK (1971). Competition, disturbance and community organization: The provision and subsequent utilization of space in a rocky intertidal community. Ecol. Monogr. 41: 351-389

Dickey TD (1989). Physical-optical-biological scales relevant to recruitment in large marine ecosystems. In: Sherman K, Alexander LM, Gold BD (eds), Large marine ecosystems: Patterns, processes and yields. American Association for the Advancement of Science, Washington, DC, p. 82-98

Diggle PJ (1990). Time series: A biostatistical introduction. Clarendon Press, Oxford

Doherty KW, Butman CA (1990). A time- or event-triggered, automated, serial, plankton-pump sampler. In: Frye D, Stone E, Martin A (eds), Advanced Engineering Laboratory project summaries. Woods Hole Oceanogr. Instn. Tech. Rpt. WHOI-90-20, Woods Hole, MA, p. 15-23

Eckman JE (1983). Hydrodynamic processes affecting benthic recruitment. Limnol. Oceanogr. 28: 241-257 
Epstein AW (1995). Physical processes and zooplankton distribution in the Great South Channel: observational and numerical studies. MIT/WHOI Joint Program in Oceanography. Ph.D. Dissertation. MIT/WHOI 95-09.

Farrell TM, Bracher D, Roughgarden J (1991). Cross-shelf transport causes recruitment to intertidal populations in central California. Limnol. Oceanogr. 36: 279-288

Fedderson F, Guza RT, Elgar S, Herbers THC (1998). Alongshore momentum balances in the nearshore. J. Geophys. Res. 103(8): 15667-15676.

Flierl GR, Davis CS (1993). Biological effects of Gulf Stream meandering. J. mar. Res. 51: $529-560$

Flierl GR, Wroblewski JS (1985). The possible influence of warm core Gulf Stream rings upon shelf water larval fish distributions. Fish. Bull. 83: 313-330

Forward RB, Jr. (1976). Light and vertical migration: Photobehavior and photophysiology of plankton. Photochem. Photobiol. Rev. 1: 157-209

Gaines S, Brown S, Roughgarden J (1985). Spatial variation in larval concentrations as a cause of spatial variation in settlement for the barnacle, Balanus glandula. Oecologia 67: $267-272$

Grosberg RK (1982). Intertidal zonation of barnacles: The influence of planktonic zonation of larvae on vertical distribution of adults. Ecology 63: 894-899

Hardy AC (1936). The continuous plankton recorder: a new method of survey. Rapp. P.-v. Réun. Cons. perm. int. Explor. Mer. 95: 35-47

Haury LR, McGowan JA, Wiebe PH (1978). Patterns and processes in the time-space scales of plankton distributions. In: Steele JH (ed.). Spatial pattern in plankton communities. Plenum Press, NY, p. 277-327

Hobbs RC, Botsford LW, Thomas A (1992). Influence of hydrographic conditions and wind forcing on the distribution and abundance of Dungeness crab, Cancer magister, larvae. Can. J. Fish. aquat. Sciences 49: 1379-1388

Jørgensen CB (1981). Mortality, growth, and grazing impact of a cohort of bivalve larvae, Mytilus edulis L. Ophelia 20: 185-192

Koehl MAR, Powell TM, Dairiki G (1993). Measuring the fate of patches in the water: Larval dispersal. In: Levin SA, Powell TM, Steele JH (eds) Patch dynamics. Lecture Notes on Biomathematics, Vol 96. Springer-Verlag, NY, p. 50-60 
Le Fèvre J (1986). Aspects of the biology of frontal systems. Adv. Mar. Biol. 23: 163299

Legendre L, Demers S (1984). Towards dynamic biological oceanography and limnology. Can. J. Fish. aquat. Sciences 41: 2-19

Lentz SJ, Carr M, Herbers THC (In Prep.). Barotropic tides on the North Carolina shelf. (for J. Geophys. Res.)

Lentz SJ, Guza RT, Elgar S, Feddersen F, Herbers THC (1999). Momentum balances on the North Carolina inner shelf. J. Geophys. Res. 104: 18205-18226.

Levin LA (1986). The influence of tides on larval availability in shallow waters overlying a mudflat. Bull. mar. Sci. 39: 224-233

Levin LA, Huggett DV (1990). Implications of alternative reproductive modes for seasonality and demography in an estuarine polychaete. Ecology 71: 2191-2208

Longhurst AR, Reith AD, Bower RE, Seibert DLR (1966). A new system for the collection of multiple serial plankton samples. Deep-Sea Res. 13(2): 213-222

Mann R (1985). Seasonal changes in the depth distribution of bivalve larvae on the southern New England shelf. J. Shellfish Res. 5: 57-64

McKillup SC, Butler AJ, McKillup RV (1995). Correlations between weather and recruitment of Nassarius pauperatus, an intertidal gastropod with a planktonic larval stage. Mar. Biol. 121: 497-500

Menge BA, Sutherland JP (1976). Species diversity gradients: Synthesis of the role of predation, competition, and temporal heterogeneity. Am. Nat. 110:351-369

Morgan SG (1995). The Timing of Larval Release. In: McEdward LR (ed), Ecology of marine invertebrate larvae. CRC Press, Boca Raton, FL, p. 157-191

Mullineaux LS, Garland ED (1993). Larval recruitment in response to manipulated field flow. Mar. Biol. 110: 93-103

Neumann D (1978). Entrainment of a semilunar rhythm by simulated tidal cycles of mechanical disturbance. J. exp. mar. Biol. Ecol. 35: 73-85

Okubo A (1994). The role of diffusion and related physical processes in dispersal and recruitment of marine populations. In: Sammarco PW, Heron ML (eds), The bio-physics of marine larval dispersal. Am. Geophys. Union, Washington, DC, p. 5-32 
Okubo A (1984). Critical patch size for plankton and patchiness. In: Levin SA, Hallam TG (eds), Mathematical ecology. Lecture Notes in Biomathematics, vol. 54. SpringerVerlag, Berlin, p. 456-477

Owen RW (1989). Microscale and finescale variations of small plankton in coastal and pelagic environments. J. mar. Res. 47: 197-240

Paine RT (1977). Controlled manipulations of the marine intertidal zone, and their contributions to ecological theory. In: Goulden CE (ed), The changing scenes in natural sciences, 1776 - 1976. Special Publication 12, The Academy of Natural Sciences of Philadelphia, Fulton, Lancaster, PA, p. 245-270

Pennington JT, Emlet RB (1986). Ontogenetic and diel vertical migration of a planktonic echinoid larva, Dendraster excentricus (Eschscholtz): Occurrence, causes, and probable consequences. J. exp. mar. Biol. Ecol. 104: 69-95

Pineda J (1991). Predictable upwelling and the shoreward transport of planktonic larvae by internal tidal bores. Science 253: $548-551$

Powell TM (1989). Physical and biological scales of variability in lakes, estuaries, and the coastal ocean. In: Roughgarden J, May RM, Levin SA (eds), Perspectives in ecological theory. Princeton University Press, Princeton, NJ, p. 157-176

Prytherch HF (1929). Investigation of the physical conditions controlling spawning of oysters and the occurrence, distribution, and settling of oyster larvae in Milford Harbor, Connecticut. Bull. US Bur. Fish. 44: 429-503

Raby D, Lagadeuc Y, Dodson JJ, Mingelbier M (1994). Relationship between feeding and vertical distribution of bivalve larvae in stratified and mixed waters. Mar. Ecol. Prog. Ser. 103: 275-284

Rennie S (1998). Wind interaction with buoyant plumes on the inner continental shelf. Ph.D. Dissertation, School of Marine Science, The College of William and Mary, Gloucester Point, VA

Rennie S, Largier JL, Lentz SJ (1999). Observations of pulsed buoyancy current downstream of Chesapeake Bay. J. Geophys. Res. 104: 18227-18240.

Roughgarden J, Pennington JT, Stoner D, Alexander S (1991). Collisions of upwelling fronts with the intertidal zone: The cause of recruitment pulses in barnacle populations of central California. Acta Oecologia 12: 35-51

Rumrill SS (1990). Natural mortality of marine invertebrate larvae. Ophelia. 32: 163198 
Scrope-Howe S, Jones DA (1986). The vertical distribution of zooplankton in the western Irish Sea. Est. Coast. Shelf Sci. 22: 785-802

Shanks AL (1983). Surface slicks associated with tidally forced internal waves may transport pelagic larvae of benthic invertebrates and fishes shoreward. Mar. Ecol. Progr. Ser. 13: 311-315

Sinclair M (1988). Marine populations: An essay on population regulation and speciation. Univ. Wash, Seattle, WA

Taggart CT, Frank KT 1990. Perspectives on larval fish ecology and recruitment processes. Probing the scales of relationships. In: Sherman K, Alexander LM, Gold BD (eds.), Large Marine Ecosystems. Patterns, Processes and Yields. American Association for the Advancement of Science, Washington, DC, pp. 151-164.

Tamburri MN, Finelli CM, Wethey DS, Zimmer-Faust RK (1996). Chemical induction of larval settlement behavior in flow. Biol. Bull. 191: 367-373

Taylor CD, Howes BL (1994). Effect of sampling frequency on measurements of seasonal primary production and oxygen status in near-shore coastal ecosystems. Mar. Ecol. Progr. Ser. 108: 193-203.

Taylor CD, Howes BL, Doherty KW (1993). Automated instrumentation for time-series measurement of primary production and nutrient status in production platform-accessible environments. Mar. Technol. Soc. J. 27: 32-44.

Tremblay MJ, Sinclair M (1990a). Diel vertical migration of sea scallop larvae Placopecten magellanicus in a shallow embayment. Mar. Ecol. Prog. Ser. 67: 19-25

Tremblay MJ, Sinclair M (1990b). Sea scallop larvae Placopecten magellanicus on Georges Bank: Vertical distribution in relation to water column stratification and food. Mar. Ecol. Prog. Ser. 61: 1-15

Underwood AJ, Deleny EJ (1984). Paradigms, explanations and generalizations in models for the structure of intertidal communities on rocky shores. In: Strong DR, Simberloff D, Abele LG, Thistle AB (eds), Ecological communities: Conceptual issues and the evidence. Princeton University Press, Princeton, NJ, p. 151-180

Wing SR, Largier JL, Botsford LW, Quinn JF (1995a). Settlement and transport of benthic invertebrates in an intermittent upwelling region. Limnol. Oceanogr. 40: 316329 
Wing SR, Largier JL, Botsford LW, Quinn JF (1995b). Spatial structure of relaxation events and crab settlement in the northern California upwelling system. Mar. Ecol. Prog. Ser. 128: 199-211

Woodin SA (1976). Adult-larval interactions in dense infaunal assemblages: Patterns of abundance. J. mar. Res. 34: 25-41

Yoder JA (1983). Statistical analysis of the distribution of fish eggs and larvae on the southeastern U.S. continental shelf with comments on oceanographic processes that may affect larval survival. Est. Coast. Shelf Sci. 17: 637-650 


\section{CHAPTER 3}

Vertical Structure in Larval Concentrations at an Inner-Shelf Site:

The Roles of Physical Processes and Larval Behavior 


\begin{abstract}
The goal of this research was to determine how inner-shelf physical processes and larval behaviors influence the distributions and transport of planktonic invertebrate larvae to potential adult habitats. Larval associations with different water masses and the vertical distributions of larvae within those water masses were quantified using vertically stratified larval samples and synoptic hydrographic data. Larvae were collected with three time-series zooplankton pumps moored vertically at a $20-\mathrm{m}$ deep site on the inner-shelf off North Carolina, USA. Ten-minute samples were collected every $3 \mathrm{hr}$ during a 3-wk period in August 1994.

High larval concentrations were documented for inner-shelf waters $\left(11,576 \mathrm{~m}^{-3}\right.$ for polychaetes, $9,780 \mathrm{~m}^{-3}$ for bivalves, $6,756 \mathrm{~m}^{-3}$ for gastropods, and $352 \mathrm{~m}^{-3}$ for brachyuran crab zoea), but concentrations were extremely variable over time. Within the context of the sampling regime, two dominant modes of variability were observed. One source of variation was associated with the synoptic meteorological time scale of 2-5 days, and the other with the diurnal time scale. Over relatively long time scales (of order 1 week), larvae were associated with particular water masses, defined by temperature-salinity characteristics. Larval polychaetes, bivalves and gastropods were more abundant in upwelled cooler, more-saline water masses below the thermocline, whereas crab zoea were more abundant in warmer, less-saline water masses. In addition, high concentrations of bivalve and gastropod larvae - possibly different assemblages of species than the cold-water groups - were occasionally found in warm water masses advected to the site during strong downwelling conditions. Within a particular water mass, group-specific vertical patterns were observed over both long and short (diurnal) time scales. "Low-frequency" temporal variations in larval concentration resulted primarily from wind-driven cross-shelf transport of water masses in which larvae were differentially distributed relative to the thermocline. Cold-water gastropod and bivalve larvae were concentrated just below the thermocline, whereas polychaete larvae were distributed throughout the depth interval below the thermocline. "Higher-frequency" variations could be attributed to diel vertical migrations in all larval groups. These findings suggest that larvae were passive to the degree that they were horizontally advected with certain water masses, but active to the degree that they could alter their vertical position in the water column.

Local hydrodynamics, larval associations with specific water masses, and the vertical structure of larvae within those water masses resulted in differential transport of larvae to potential adult habitats. Larval data indicate the times and places of possible coupling between water-column organisms and the benthos, leading to certain predictions regarding when and where larval settlement should be greatest. Settlement of polychaetes should be more consistent and occur over longer periods of time and a wider span of the inner-shelf. In contrast, settlement of bivalves and gastropods is expected to be more episodic, occur during strong downwelling events, and be concentrated in shallower regions of the inner shelf where the downwelled thermocline intersects the bottom. In addition there may be a diel cycle in larval settlement. Determining how processes operating at the synoptic and diurnal time scales are coupled and to what extent they influence recruitment variability represents a challenging extension of this work for the future.
\end{abstract}




\subsection{INTRODUCTION}

The inner-shelf region of the continental shelf, defined here as the region between the nearshore ( $<5 \mathrm{~m}$ depth) and the shoreward side of the continental shelf $(<30 \mathrm{~m}$ depth), is a site marked by intense biological activity and complex physical processes operating at a variety of scales. Biologically, inner shelves are productive areas, where planktonic larval dispersal occurs for many species of benthic invertebrates (Boicourt 1988). The inner shelf not only provides subtidal soft-sediment habitats for benthic invertebrates, it also provides links among nearshore, intertidal, and estuarine habitats. Physically, inner shelves are dynamic regions, and it is likely that diverse physical processes may lead to planktonic larval patchiness in time and space. Moreover, the spatial and temporal dynamics of planktonic larval distributions may account for much of the unexplained variability in the population distributions and dynamics of benthic adults in these and other regions (e.g., Yoshioka 1982; Connell 1985; Roughgarden et al. 1988 and 1991; Gaines et al. 1985).

Fine- $(1 \mathrm{~m}-1 \mathrm{~km})$ to meso- $(100-1000 \mathrm{~km})$ scale (as defined by Haury et al. 1978) and relatively short (hours to several weeks) time-scale physical processes, such as wind-driven upwelling and downwelling, fronts, eddies, tides, internal waves, tidal bores, waves and storms, will likely have the most significant impact on larvae that disperse in the water column for several weeks to several months (e.g., Boicourt 1988; Pineda 1991; Shanks 1995). In addition, biological factors such as vertical migratory behaviors tuned to the diel light/dark cycle, presence or absence of food and predators, spawning events, growth, and natural mortality can interact with physical processes and contribute to 
heterogeneity in larval distributions on similar scales (Tremblay and Sinclair 1990; Rumrill 1990; Morgan 1995).

On the east coast of North America, winds blowing toward the north/northeast initiate upwelling, where water is advected offshore at the surface (i.e., to the right of the wind direction) and balanced by a shoreward movement of bottom waters upwelling at the coastal boundary (Ekman 1905; Smith 1968; Barber and Smith 1981; Richards 1981). If the water column is thermally stratified, isotherms become up-turned at the coast. When the winds diminish or change direction, relaxation of upwelling occurs at the coast and isotherms become nearly horizontal. Alternatively, in the presence of strong winds blowing toward the south/southwest, downwelling occurs, and the down-turned thermocline is advected offshore. Thus, during such periods of wind-driven cross-shelf circulation (i.e., upwelling and downwelling), the water column develops into a two-layer system where the surface and bottom layers are flowing in opposite directions. Direction of larval transport by these currents would depend on the vertical position of larvae in the water column (e.g., Bowden 1965; Okubo 1967; Kullenberg 1972 and 1978). Planktonic larvae occurring below the thermocline during upwelling events and those in surface waters during downwelling events will move shoreward.

Vertical stratification of planktonic organisms may occur as a result of both passive and active mechanisms. When planktonic larvae are not swimming, passive vertical stratification of larvae occurs through both biological or physical processes. For example, an increase in near-bottom larval concentration may result from spawning activities of local benthic invertebrates. Depth-dependent decreases in larval 
concentration may result from differential mortality via planktonic or benthic predation. Furthermore, natural, ontogenetic changes in larval density may occur through increased calcification of shell structures or depletion of lipid-rich food reserves. Thus, many latestage larvae are found in near-bottom waters (Thorson 1964; Pennington and Emlet 1986; but, see Young 1995). Physical processes that result in vertical stratification of larvae include depth-dependent processes of turbulent mixing or advection.

Vertical stratification of larvae may also result from an active behavioral response. Swimming speeds of meroplanktonic larval organisms (ca. $0.001-4.2 \mathrm{~cm} \mathrm{sec}^{-}$ '; Mileikovshy 1973; Chia et al. 1984), while slower than those for larger zooplankters, are generally sufficient to compensate for typical settling speeds (ca. $0.2-2 \mathrm{~cm} \mathrm{sec}^{-1}$; Mileikovshy 1973; Chia et al. 1984) and allow for active migration on a daily basis (Mileikovsky 1973; Forward 1976; Chia et al. 1984; Mann et al. 1991). Rather than carrying out elaborate diel vertical migrations, larvae may simply respond to the vertical stratification of environmental factors (e.g., temperature, salinity, turbulence, food, and predators), and position themselves within a favorable water mass or microcosm (e.g., Banse 1986; Owen 1989).

Recruitment events of barnacles and crabs have been attributed to the relaxation of upwelling along the West Coast of North America (e.g., Farrell et al. 1991; Roughgarden et al. 1991; Wing et al. 1995; Connolly and Roughgarden 1999). Each of these studies observed a correlation between larval recruitment and hydrographic variables associated with the relaxation of upwelling-favorable winds, and hypothesized that differences in recruitment were due to larvae residing in water masses that contact 
the shore at different times. Farrell et al. (1991) provided limited data of larval concentration at a single depth to support this hypothesis. The studies of Roughgarden et al. (1991), Wing et al. (1995), and Connolly and Roughgarden (1999) measured recruitment into benthic communities, but planktonic distributions were not sampled. Descriptions of the vertical distribution of planktonic invertebrate larvae and their associations with different water masses over the inner shelf are rare (e.g., Turner and Dagg 1983; Mann 1985, 1986; Scrope-Howe and Jones 1986; Tremblay and Sinclair 1988, 1990a; Miller and Emlet 1997).

Thus, in past studies, temporal and vertical distributions of planktonic larvae have been inferred from settlement patterns (e.g., Roughgarden et al. 1991; Wing et al. 1995) or evaluated directly using non-synoptic, short-term 24- or 48-hr station data (e.g., Banse 1986; Scrope-Howe and Jones 1986; Tremblay and Sinclair 1990) or samples collected at a single depth (e.g., Farrell et al. 1991; Miller and Emlet 1997; Chapter 2).

The ultimate goal of this research was to determine how inner-shelf physical processes, such as wind-driven upwelling and downwelling, and biological behaviors influence the distributions and transport of larval bivalves, gastropods, polychaetes and brachyuran crabs to potential adult habitats. The specific objectives of this research were: (1) to quantify the vertical distributions, temporal variations, and water mass associations of planktonic larvae at an inner-shelf site on time scales of several hours to several weeks and vertical spatial scales of several meters; and (2) to account for the temporal variations and vertical distributions mechanistically by coupling synoptic biological and physical time-series data. Identifying the physical and behavioral 
processes that may be responsible for generating the observed temporal and vertical variations in larval concentrations may elucidate the coupling between larval supply and larval settlement. Furthermore, results from this study can be used to suggest the design of future field studies on the causes of larval patch formation, maintenance and transport.

In contrast to previous studies, the foundation of the present study is the simultaneous collection of larvae at three depths by moored plankton pumps sampling every $3 \mathrm{hr}$ over a 3 -wk period. Therefore, this study provides direct (versus inferred) measurements of larval concentration with increased vertical and temporal resolution over a relatively long period of time. In addition, extensive synoptic physical data were collected during this study, allowing a more detailed exploration into the potential role of physical and behavioral processes in modulating variations in larval distributions.

\subsection{METHODS}

\subsubsection{Study Location}

The study site was located on the inner shelf off of the Outer Banks at Duck, North Carolina, USA ( $36^{\circ} 10.895^{\prime}$ N Latitude, $75^{\circ} 45.068^{\prime}$ W Longitude; Fig. 1.4), roughly halfway between Cape Henry and Cape Hatteras. The area has a nearly straight coastline with an orientation of $340^{\circ}$. The bathymetry slopes gently off to the east over a $100-\mathrm{km}-$ wide continental shelf. The inner-shelf occupies roughly the shoreward $30 \mathrm{~km}$ of the shelf, from 5 to $30 \mathrm{~m}$ depth. The inner shelf bottom is mostly fine sand and mud (Kim et al. 1997), with occasional hard-substrates on piers and rock jetties. The Outer Banks are located on the seaward side of numerous brackish sounds. Rudee Inlet and the 
Chesapeake Bay (75 km to the north) and Oregon Inlet (50 km to the south) allow exchange of water and animals between the sounds and Atlantic Ocean.

In addition to its physical characteristics, this study site was chosen because the U.S. Army Corp of Engineers operates a Coastal Engineering Research Center Field Research Facility (FRF) at the site. To augment field research on nearshore processes, the FRF maintains a 561-m long research pier that extends offshore beyond the 8-m contour and supports numerous oceanographic, sedimentological, and meteorological instruments (Birkemeier et al. 1985).

\subsubsection{Sampling Techniques}

Larval samples were collected using three Moored Automated Serial Zooplankton Pumps (Doherty and Butman 1990, Butman 1994; Fig. 1.5) that were moored vertically at the 21-m isobath (approximately $5 \mathrm{~km}$ from shore; Fig 3.1). Designed to minimize instrument-induced disturbances to animals for unbiased collections, the entrance region to the intake is formed by two horizontal, circular plates separated by $15 \mathrm{~cm}$. The intake is in the center of the upper plate. Seawater is delivered to the pump intake region by the ambient current. A water sample is pumped up through a 1-mm mesh prefilter spanning the intake region, and into a channel where organisms are collected on a strip of $100-\mu \mathrm{m}$ mesh. Thus, organisms larger than $100 \mu \mathrm{m}$ (i.e., the shortest dimension of the $100-\mu \mathrm{m}$ collection mesh) but smaller than $1415 \mu \mathrm{m}$ (i.e., the longest dimension, or diagonal, of the $1-\mathrm{mm}$ mesh prefilter) are retained. Once a discrete sample is collected, it is covered 


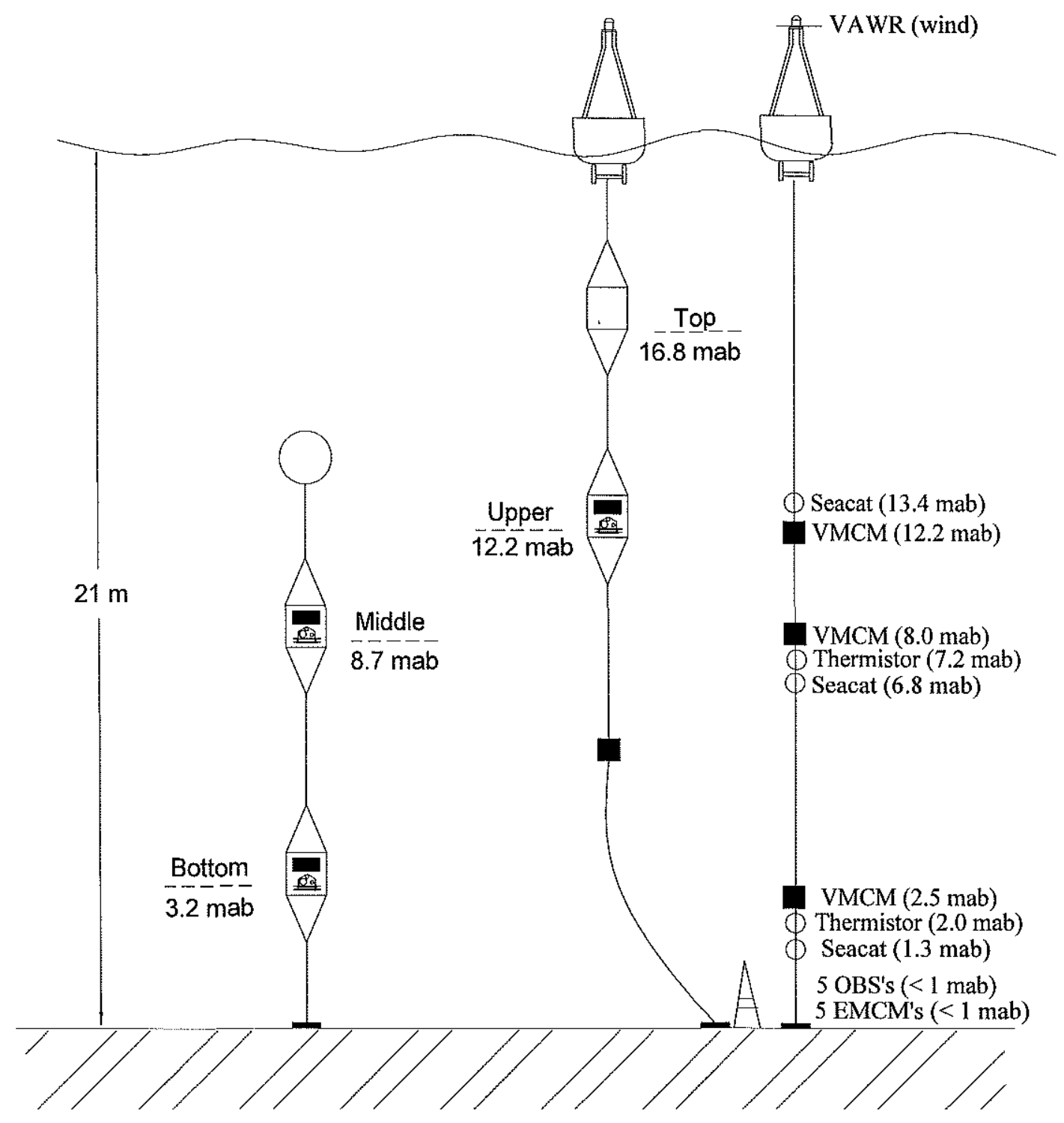

Figure 3.1 Configuration of the moored plankton pumps and physical instruments at the 20-m site, August 1994. Heights in meters above the bed (mab) are given. Pumps were located at $12.2 \mathrm{mab}(8.8 \mathrm{~m})$ for the upper pump, $8.7 \mathrm{mab}(13.3 \mathrm{~m})$ for the middle pump, and $3.2 \mathrm{mab}(17.8 \mathrm{~m})$ for the bottom pump. The top pump, originally positioned at $16.8 \mathrm{mab}(4.15 \mathrm{~m})$ to sample above the thermocline, was lost during a storm. Seacats recorded water temperature and conductivity, VMCM's (Vector Measuring Current Meters) and EMCM's (Electromagnetic Current Meters) recorded current velocity, the VAWR (Vector Averaging Wind Recorder System) recorded wind speed and direction, thermistors recorded water temperature, and the OBS's (Optical Backscattering Sensors) recorded suspended sediment concentrations within the boundary layer. 
by another strip of $100-\mu \mathrm{m}$ mesh. The two strips, with the sample in between, are wound onto a take-up spool that resides in a nominal $3.7 \%$ formalin bath (buffered with $\mathrm{CaCO}_{3}$ ) for long-term storage in situ. This sample storage mechanism is fashioned after the towed Longhurst-Hardy Plankton Recorder (Hardy 1936, Longhurst et al. 1966).

The three time-series pumps sampled at 3-hr intervals over a 3-wk period, commencing at 00:00 hr on August 11 and ending at 21:00 on August 30, Local Mean Time (LMT). The targeted water volume filtered was 250 liters at all times. The volume flux was approximately 25 liters $\mathrm{min}^{-1}$, therefore it took about $10 \mathrm{~min}$ to take a 250 -liter sample. Results from a smaller-scale study conducted in the same region during the

previous year (Chapter 2) indicated that sampling every $3 \mathrm{hr}$ was adequate to capture the dominant variability in the targeted larval groups and that a 250 -liter plankton sample would provide an adequate number of larvae to be used in statistical tests.

The pumps were positioned at 3.2, 8.7 and 12.2 meters above the bottom (mab), and are hereafter referred to as the "bottom pump", "middle pump" and "upper pump", respectively (Fig. 3.1). Divers scraped fouling organisms and accumulated sediment off the surfaces of the plankton pumps several times and adjusted formalin concentrations at least twice during the deployment period.

\subsubsection{Sample Processing}

Upon recovery, individual formalin-preserved plankton samples were cut from the mesh and transferred to $80 \%$ ethanol with Rose Bengal stain. Subsequent treatment of samples 
differed slightly between the samples collected at the middle pump location and those collected at the upper and bottom pump locations.

Plankton samples collected by the upper and bottom pumps were washed from the mesh with freshwater, rinsed over a $90-\mu \mathrm{m}$ sieve, and split 4 ways using a modified Folsom Plankton Splitter (McEwen et al. 1954; Scarola and Novotny 1968; Omori and Ikeda 1984). The modifications were the addition of four-chambers to the splitter and using air bubbles to keep the animals in suspension while being subsampled. In most cases a single quarter-split was sorted under a stereoscopic microscope. Larvae were enumerated and grouped into the following major taxa: polychaetes (worms), bivalves (clams), gastropods (snails) and crustacean zoea (brachyuran crabs). Early-stage trochophore larvae were not included in total polychaete counts because other taxonomic groups also have a trochophore larval stage.

Preserved plankton samples collected by the middle pump location were washed from the mesh with freshwater, rinsed over a $90-\mu \mathrm{m}$ sieve, and pre-sorted using methods of density centrifugation (methods adapted from Price et al. 1978; Schwinghamer 1980; Gallager and Mann 1986; Tremblay et al. 1987; Starink et al. 1994). As the name implies, density centrifugation separates organisms in a sample according to density differences. In this study, $25 \mathrm{ml}$ of a colloidal silica solution (Ludox AM, Dupont Chemicals, Wilmington, DE; specific gravity of 1.2091 and a $\mathrm{pH}$ of 9.0 ) was added to a 50-ml centrifuge tube. After a plankton sample was concentrated in less than $25 \mathrm{ml}$ of freshwater, it was carefully layered on top of the colloidal silica solution with a Pasteur pipette. The samples were then spun at maximal speed (rpm unknown) for $5 \mathrm{~min}$ in a 
clinical centrifuge. Most zoea and barnacle cyprid larvae were trapped at the air/water interface. Polychaete larvae, copepods, diatoms and flocculent material were concentrated at the interface between the freshwater above and the colloidal silica solution below. Bivalves, gastropods, some polychaetes, pteropods, some zoea and barnacle cyprids, benthic forams, fecal pellets, and sand settled to the bottom of the tube. This bottom fraction was processed further.

Bivalve and gastropod larvae were enumerated. Polychaetes and zoea were not enumerated because some individuals were less dense than colloidal silica and settled into a different fraction than the one isolated for inspection. Several targeted bivalve genera or species were identified whenever possible (see Appendix A). Initial identifications were based on evaluation of subtle differences in shell morphology using a stereomicroscope. Groups of larval bivalves identified in this manner were subsampled and their hinge structure photographed under an ETEC Autoscan Scanning Electron Microscope (e.g., Turner and Boyle 1975; Lutz and Jablonski 1978; Lutz et al. 1982). To confirm species identifications these photographs were then compared with an extensive set of SEM micrographs for 55 species of sympatric bivalves (R.A. Lutz, Rutgers University, personal collection).

Identifications were confirmed for Tellina spp., Spisula solidissima, Anadara spp., Ensis directus, Cyrtopleura costata, and Barnea sp. The Spisula solidissima category probably also contained some Mercenaria mercenaria. Furthermore, Cyrtopleura costata, and Barnea sp. were combined into the Family Pholadidae. Taxonomic identifications were not reliable for other bivalve larvae that may have been 
prevalent at the study site, such as Mya, Anomia, Argopecten, Mytillidae, and Mulinia. In many cases, the plankton pump storage mechanism squashed the bivalve specimens beyond recognition as species, so only a fraction $(0-90 \%)$ could be identified definitively beyond major taxonomic group. Species data were not used for quantitative analyses because the percentage of identifiable species in the non-crushed fractions does not necessarily represent the same percentage of that species in the crushed fractions (i.e., crushing problems may be species-specific as opposed to random). Furthermore, susceptibility to crushing may have been a function of time and bivalve density in addition to species. However, similar patterns were observed in the species time series whether or not the crushing problem was species-specific. Thus, the data were used to identify general patterns of abundance.

At all sampling locations, the polychaete grouping included mostly spionid larvae. Prionospio spp., Spio spp. and Polydora spp. were identified as the numerical dominants in many samples, but the species were not quantified. The gastropod grouping may have contained prosobranch gastropods of both holoplanktonic (e.g., larval heteropods) and meroplanktonic (e.g., Bittium spp. and Littorina spp.) forms. The zoea category contained one or more species of brachyuran crabs.

\subsubsection{Time Series Analysis}

Statistical analyses of the time series were carried out using correlative analyses on data that were lagged in both directions with time steps of $3 \mathrm{hr}$. The series mean was removed from a time series prior to analysis. Decorrelation times — defined by the point 
where the autocorrelation function crosses the $\mathrm{x}$-axis $(\mathrm{y}=0)$ - provided the number of independent realizations observed in autocorrelated larval concentration or physical time series, and were used to determine statistical significance of cross-correlation analyses. Degrees of freedom $(d f)$ were calculated as follows: $d f=\mathrm{N} \Delta t / \mathrm{DT}$, where $\mathrm{N} \Delta t$ is the total length of the record (160 samples), and DT is the autocorrelation decorrelation time (Emery and Thomson 1997). All reported cross-correlations account for autocorrelation of the lowest-frequency process. All statistical tests were done using MATLAB (version 5.2; The MathWorks, Inc.) and SYSTAT (version 7.0; SPSS, Inc) software.

Possible associations between biological and physical processes were explored using cross-correlation analyses between the larval concentration and physical time series at a variety of time lags, and the decorrelation time-scale information. Because the plankton pumps sampled for approximately $10 \mathrm{~min}$. every $3 \mathrm{hr}$, the physical time-series data were pooled over the same intervals. Ten-minute averages were calculated for each physical time series, and values every $3 \mathrm{hr}$ were used for the cross-correlation analyses.

Larval concentration time series were compared with time series of hydrographic data collected within $2 \mathrm{~m}$ vertically and $500 \mathrm{~m}$ horizontally of the comparable pump samples (Fig 3.1; see Chapter 1 section 1.6; Butman 1994; Alessi et al 1996). Considering the vertical spatial scales of physical variability (Fig. 3.2; Lentz et al. 1999), these vertical separation distances between the physical and biological data sets were acceptable. Horizontal scales of variability typically exceeded several kilometers, except in the vicinity of the up- or down-turned thermocline (e.g., Waldorf et al. 1995; Shay 


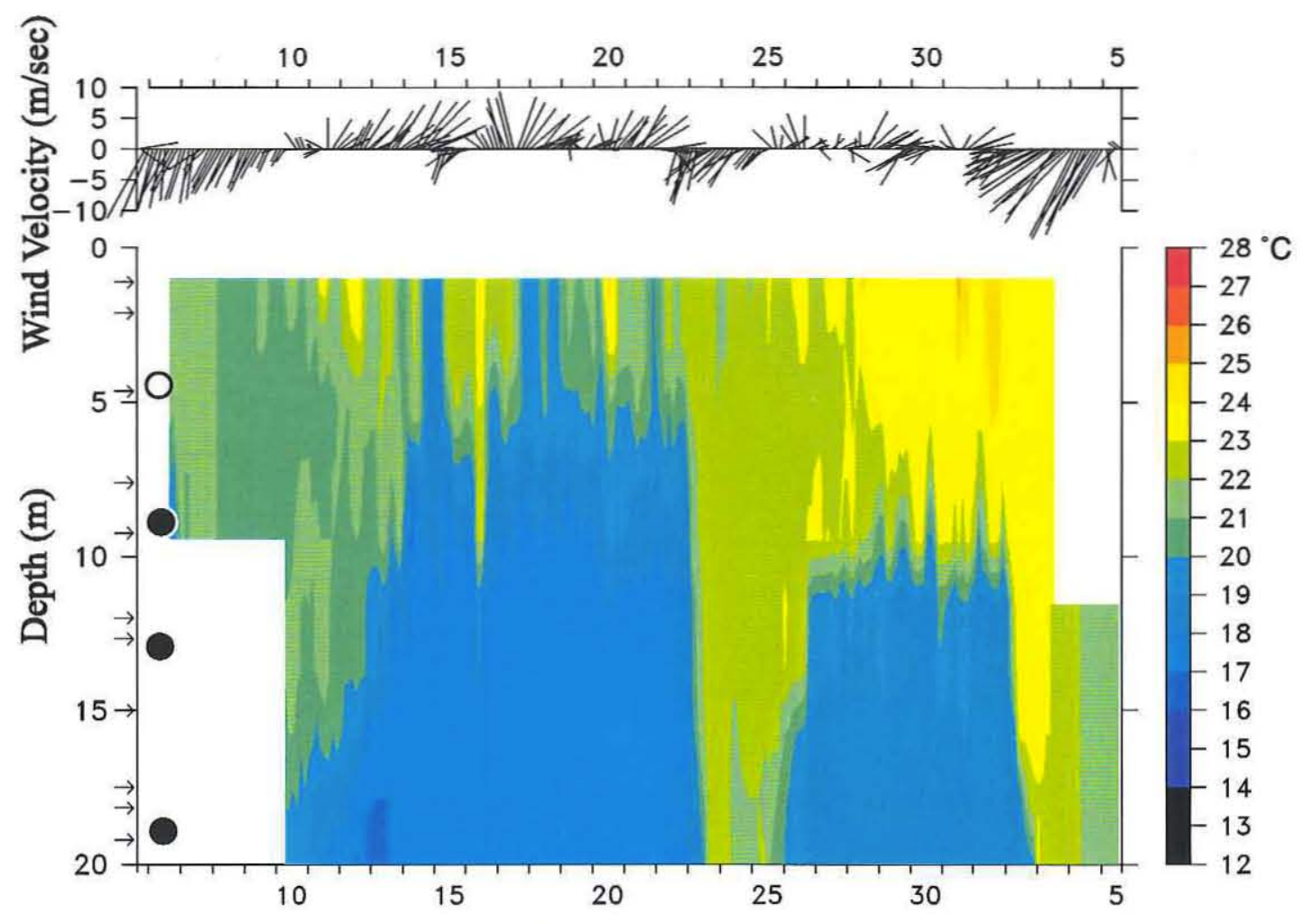

August - September 1994 (days)

Figure 3.2 Time series of water temperature $\left({ }^{\circ} \mathrm{C}\right)$ at the 20 -m site, with wind velocity shown in the top panel. Wind vectors point in the direction the wind is blowing (degrees True). Vectors have been rotated by $20^{\circ}$ counterclockwise, such that straight up indicates alongshore wind directed toward $340^{\circ}$. Solid circles on the depth axis indicate depths where plankton samples were obtained, the empty circle indicates a plankton pump that was lost in a storm, and arrows indicate depths of thermistors. All times are given in Local Mean Time (LMT), which was Daylight Savings Time during the study (Eastern Standard Time $+1 \mathrm{hr}$ ).

Water temperature time series reflects a stratified water column responding to upwelling- and downwelling-favorable wind stress. Periods of northeastward wind created upwelling-favorable conditions with colder water near the surface. In contrast, periods of southwestward winds created downwelling-favorable conditions during which warm water was advected from near shore. (Figure kindly provided by S. Lentz) 
et al. 1998). Furthermore, water temperatures recorded at the plankton pumps were coherent with temperatures at the corresponding thermistors on the physical moorings. These results suggest horizontal homogeneity extending beyond $500 \mathrm{~m}$ horizontally, and that the horizontal separation distances between biological and physical data sets were also acceptable. Wind speed and direction, as well as other meteorological data including short-wave radiation, were recorded on a surface mooring located at the 20 -m site, within $500 \mathrm{~km}$ horizontally of the plankton pump moorings (Alessi et al 1996). Bottom tetrapods, recording suspended sediment concentration and current velocity within $1 \mathrm{~m}$ of the bed, were 0.8 (August 11-19) - $1.4 \mathrm{~km}$ (August 19-30) shoreward of the plankton pumps and physical moorings (L.D. Wright, unpubl. data). Despite the fact that the tetrapods were not co-located with the pumps and moorings, the current shear velocities and sediment concentrations are reflective of the general patterns in near-bottom conditions at the study site (C. Friedrichs, pers. comm.).

\subsection{OCEANOGRAPHIC SETTING AT THE STUDY SITE}

The oceanographic setting at the Duck, NC inner-shelf study site (Fig. 1.4) during 1994 has been described (Kim et al. 1997; Fedderson 1998; Shay et al. 1998; Austin 1999; Austin and Lentz 1999; Lentz et al. 1999; and Rennie et al. 1999). Descriptions were based on data from a cross-shelf moored array of hydrographic, meteorological and sedimentological instruments (Fig. 1.5; data reported by Alessi et al. 1996) and extensive 
shipboard CTD surveys covering $120 \mathrm{~km}$ alongshore and $50 \mathrm{~km}$ cross-shelf (data reported by Waldorf et al. 1995).

The major factor influencing inner-shelf dynamics during this study was meteorological forcing (e.g., winds and waves produced by the winds; Figs. 3.2 - 3.3), varying on synoptic time scales of 2-8 days (Fedderson et al. 1998; Austin and Lentz 1999; Lentz et al. 1999). Alongshore winds determined the extent of stratification/ vertical mixing (Austin 1999), initiated cross-shelf flows associated with upwelling and downwelling (Lentz et al. 1999), generated swift alongshore currents (Fedderson 1998; Lentz et al. 1999; Rennie et al. 1999), and influenced whether or not a low-salinity plume exited from the Chesapeake Bay Estuary and moved southward toward the study site (Rennie et al. 1999).

Intermittent upwelling and downwelling events occur at the study site at approximately 3- to 5-day intervals (Boicourt 1973, Birkemeier et al. 1985, Alessi et al. 1996; Austin and Lentz 1999; Figs. 3.2 and 3.3). Three atmospheric cold fronts passed through the study region on August 15, 22 and 29, generating strong southwestward winds in their wake that drove the downwelling conditions observed on August 15-16, 23-25, and briefly on August 29 and 30 (Austin 1999; Figs. 3.2 and 3.3). Otherwise, more typical upwelling regimes existed during the following periods: August $12-15,17-$ 19, 21-22, and 26-27. An atmospheric cold front passed through the region just prior to the study and drove the downwelling conditions observed at the start (August 11-12) of the study (Figs. 3.2 and 3.3). 
(a)

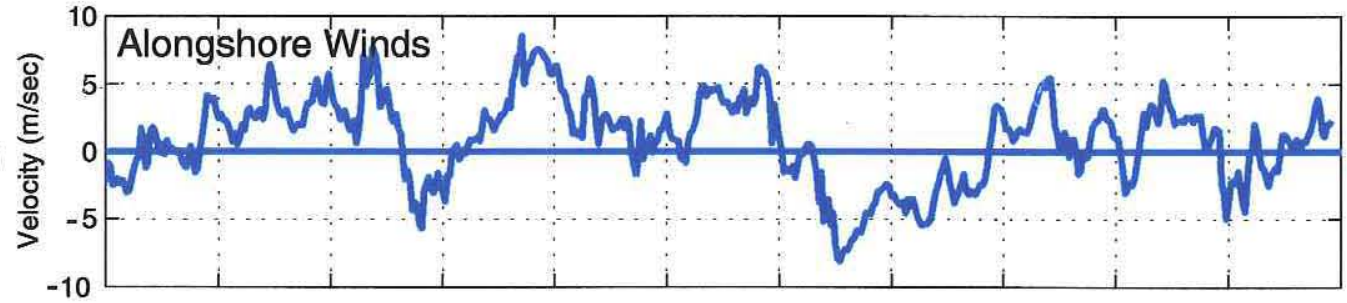

(b)

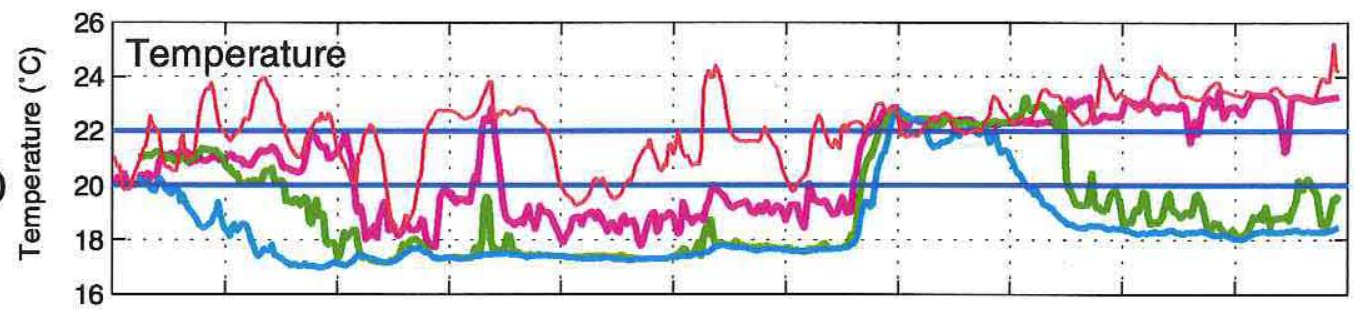

(c)

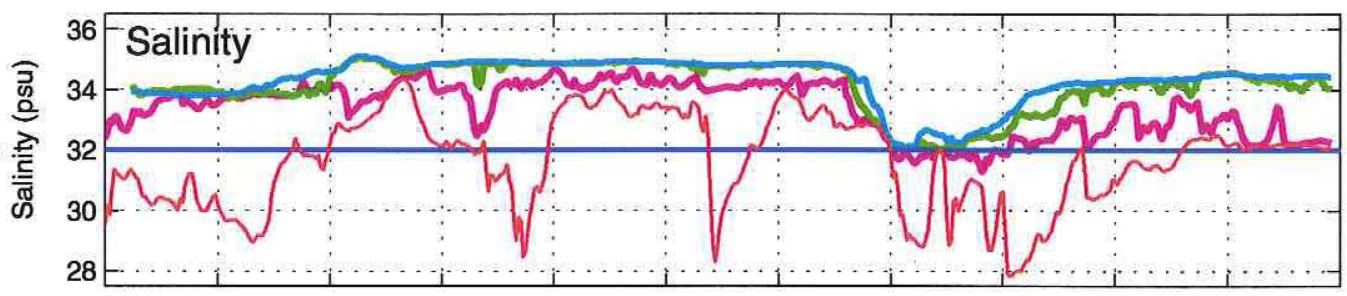

(d)
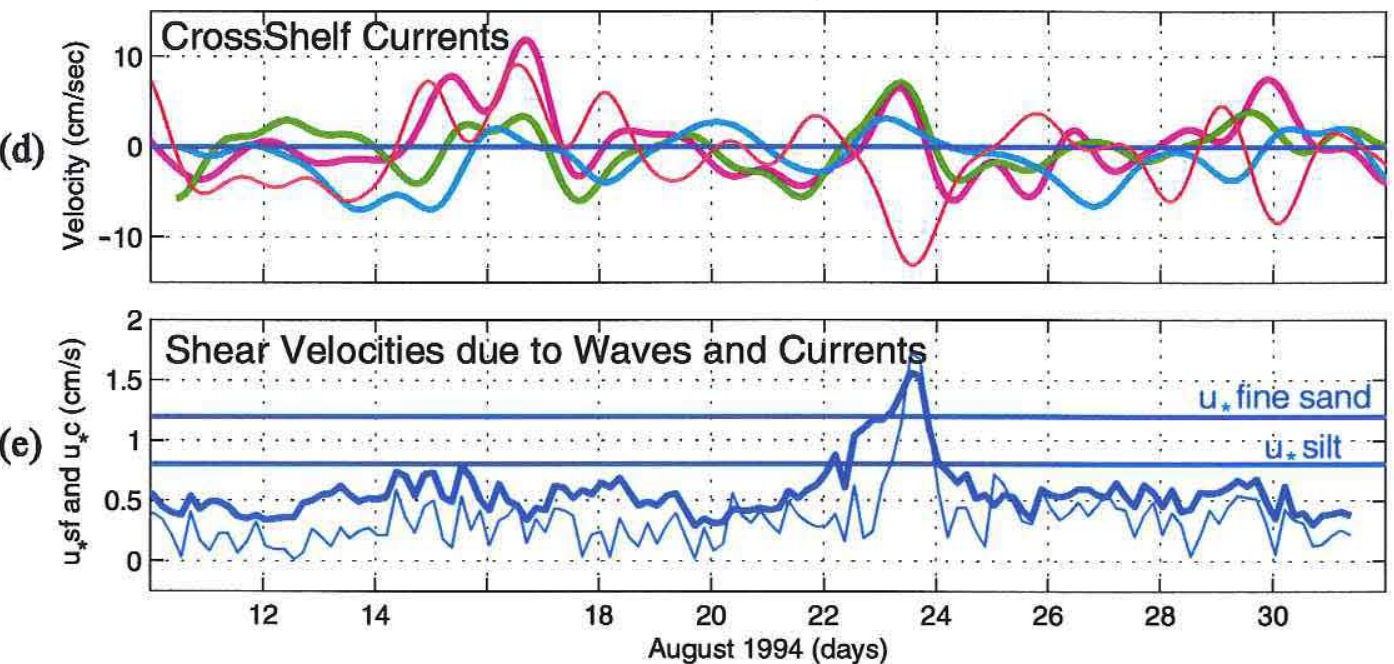

Figure 3.3 Oceanographic conditions at the 20-m site during the August 11-30 study period (using data reported by Alessi et al. 1996; Lentz et al. 1999; Austin and Lentz 1999; L.D. Wright unpub data). Meteorological forcing (a) and the response of temperature (b), salinity (c), cross-shelf currents (d), and near-bottom shear velocities (e) due to waves ( $u^{*}$ sf; bold curve) and currents ( $u^{*} c$; thin curve). Upper and lower temperatures associated with the thermocline are delineated by dark blue horizontal lines (panel a; as reported by Waldorf et al. 1995). Maximal salinitiy associated with the Chesapeake Bay plume is delineated by dark blue horizontal line (panel c; as reported by Rennie et al. 1999). Critical shear velocities required to initiate motion in coarse and fine sands are identified by the upper and lower horizontal lines, respectively (panel e). All graphs are color coded using the following convention: magenta for conditions near the upper pump sampler, green for conditions near the middle pump sampler and cyan for conditions near the bottom pump sampler. Thinner red lines, if present, correspond to the conditions at the surface. All physical data have been hourly-averaged. Cross-shelf velocity had been low-pass filtered to remove all motions with periods less than or equal to 12 hours (semi-diurnal tide). 
During August 1994, a strong seasonal thermocline existed over the inner shelf at 5-10 m depth, with water temperatures of $22-25^{\circ} \mathrm{C}$ above the thermocline and $16-20^{\circ} \mathrm{C}$ below (Fig. 3.3; Waldorf et al 1995; Lentz et al. 1999). The vertical thermal structure of the water column was influenced primarily by surface heating and by advection of different water masses resulting from meteorological forcing (Austin 1999; Austin and Lentz 1999; Lentz et al. 1999). During periods of sustained downwelling-favorable winds, the thermocline penetrated deeper in the water column, leading to a vertically homogeneous water column (e.g., August 23-25). This was due to the advection of warmer surface waters and the thermocline moving down-slope along the bottom as it was advected offshore. Large temporal variations in water temperature resulted primarily from cross-shelf advection of different water masses rather than from alongshore advection (Austin and Lentz 1999; Lentz et al. 1999). In general, a homogeneously warm water column during the August study period was not due to mixing because the heat content of the water column was different before and after strong downwellingfavorable winds (Austin 1998 and 1999). Complete vertical mixing of the water column did not occur until after the study (September 4). Moreover, the downwelled thermocline did not intersect the bottom at sites beyond approximately $7-10 \mathrm{~km}(\sim 20-25 \mathrm{~m}$ water depths) from shore during the study (Waldorf et al. 1995; Alessi et al. 1996).

In contrast to temperature variability, variability in salinity or density (which was dominated by salinity) was caused primarily by alongshore advective rather than by cross-shelf advective events (Lentz et al. 1999; Rennie et al. 1999; Fig. 3.3). Salinity 
anomalies were due to the presence of the Chesapeake Bay plume, identified by its lowsalinity water $(<32 \mathrm{psu})$ and occasionally by increases in turbidity and fluorescence (Boicourt et al. 1987; Rennie et al. 1999). Presence of the plume was episodic, cooccurring with downwelling-favorable wind events on meteorological time scales of 4-5 days (Rennie 1998; Rennie et al. 1999). One main plume event occurred just prior to the study period, and three events occurred during the study period: August 8, 17, 21 and August 24-26 (Fig. 3.3). The last was the largest and longest. The plume was generally concentrated within the upper $10 \mathrm{~m}$ of the water column and inshore of the $21-\mathrm{m}$ isobath, but thinned, spread offshore and dissipated during upwelling-favorable wind conditions. Otherwise, salinities characteristic of shelf waters $(\sim 32-34 \mathrm{psu})$ were observed.

Currents over the inner shelf tended to be oriented alongshore in the direction of the wind. Southwestward winds produced alongshore currents in excess of $75 \mathrm{~cm} \mathrm{sec}^{-1}$ (Fedderson et al. 1998, Lentz et al. 1999; Table 3.1). Cross-shelf flows were considerably slower, averaging approximately $5 \mathrm{~cm} \mathrm{sec}^{-1}$, and occasionally exceeding 20 $\mathrm{cm} \mathrm{sec}^{-1}$ during periods of strong upwelling and downwelling. Offshore-directed flow at the surface and onshore-directed flow below the thermocline typified upwelling conditions, and flows reversed during downwelling conditions. During periods when the water column was thermally uniform, the region of flow reversal was approximately half the water depth. The semi-diurnal tides characteristic of this inner-shelf site produced a nominal M2 tidal flow of less than $5 \mathrm{~cm} \mathrm{sec}^{-1}$ (Alessi et al. 1996, Lentz et al. [in prep], Rennie et al. 1999). 
Table 3.1 Summary statistics of larval concentration and physical time-series data. U, M and B refer to upper, middle and bottom pump depths, respectively.

\begin{tabular}{|c|c|c|c|c|c|}
\hline Variable & Min & $\operatorname{Max}$ & Median & Mean & STD \\
\hline Bivalve-U (\#/m $\left.\mathrm{m}^{3}\right)$ & 16 & 9780 & 864 & 1419.1 & 1516.5 \\
\hline Bivalve-M & 16 & 8756 & 1010 & 1264.6 & 1183.3 \\
\hline Bivalve-B & 176 & 8108 & 978 & 1296.9 & 1167.9 \\
\hline Gastropod-U & 0 & 6756 & 588 & 734.3 & 813.7 \\
\hline Gastropod-M & 8 & 4416 & 255 & 374.7 & 484.5 \\
\hline Gastropod-B & 64 & 4520 & 506 & 637.4 & 559.7 \\
\hline Polychaete-U & 0 & 10520 & 182 & 1217.5 & 2086.5 \\
\hline Polychaete-B & 16 & 11576 & 1620 & 2251.1 & 2279.8 \\
\hline Zoea-U & 0 & 320 & 0 & 17.4 & 43.04 \\
\hline Zoea-B & 0 & 352 & 0 & 18.0 & 40.9 \\
\hline Temperature $\left({ }^{\circ} \mathrm{C}\right)$ & 17.01 & 23.33 & & & \\
\hline Salinity (psu) & 31.19 & 35.10 & & & \\
\hline & & & & & \\
\hline Density (Sigma-t) & 21.27 & 25.52 & & & \\
\hline & & & & & \\
\hline CS-Current-E $(\mathrm{cm} / \mathrm{s})$ & 0 & 23.12 & & & \\
\hline CS-Current- W & 0 & 20.70 & & & \\
\hline AS-Current-N $(\mathrm{cm} / \mathrm{s})$ & 0 & 38.96 & & & \\
\hline $\begin{array}{l}\text { As-Current-ly (cm/s) } \\
\text { AS-Current- S }\end{array}$ & $\frac{0}{0}$ & $\frac{38.90}{75.02}$ & & & \\
\hline & & & & & \\
\hline CS Wind-E $(\mathrm{m} / \mathrm{s})$ & 0 & 8.64 & & & \\
\hline CS Wind-W & 0 & 7.71 & & & \\
\hline & & & & & \\
\hline AS Wind-N $(\mathrm{m} / \mathrm{s})$ & 0 & 8.54 & & & \\
\hline AS Wind-S & 0 & 8.12 & & & \\
\hline Wind Speed & 071 & 916 & & & \\
\hline Wind speed & 0.71 & 9.10 & & & \\
\hline
\end{tabular}


Within $1 \mathrm{~m}$ of the bed, suspended sediment concentrations were highly variable and responded to local-scale (versus synoptic-scale) winds (Kim 1996; Kim et al. 1997) and waves. During periods of intensive waves, shear (friction) velocities ( $\left.\mathrm{u}_{*_{\mathrm{sf}}}\right)$ exceeded the critical shear velocity $\left(\mathrm{u} *_{\text {crit. }}\right)$ necessary for initiating motion of the silt and fine sand fractions (i.e., sediments that most closely match the range of sizes and densities of larval invertebrates; C.A. Butman pers. comm.), leading to local resuspension. As expected, suspended sediment concentration very close to the bottom increased due to local resuspension during periods of intense downwelling (e.g., August 23-25; L.D. Wright unpubl. data).

\subsection{RESULTS}

\subsubsection{General Characteristics of Larval Concentration Time Series}

Three general characteristics were observed in the larval concentration time series (Figs. 3.4 -3.7). First, the larval time series for each major taxonomic group exhibited strong signals that could not be explained as random variations. For example, concentrations for each larval group were not uniform with depth, and exhibited specific associations with physical variables such as water temperature (Figs. 3.4-3.7; see section 3.4.2). Second, high larval abundances were observed at all three depths in the water column. Maximal concentrations were $11,576 \mathrm{~m}^{-3}$ for polychaetes, $9,780 \mathrm{~m}^{-3}$ for bivalves, $6,756 \mathrm{~m}^{-3}$ for gastropods, and $352 \mathrm{~m}^{-3}$ for zoea (Table 3.1). Third, there were large temporal variations in larval concentrations on time scales of several hours to several days, and the character of these temporal variations differed with taxonomic group and depth. In some groups, 

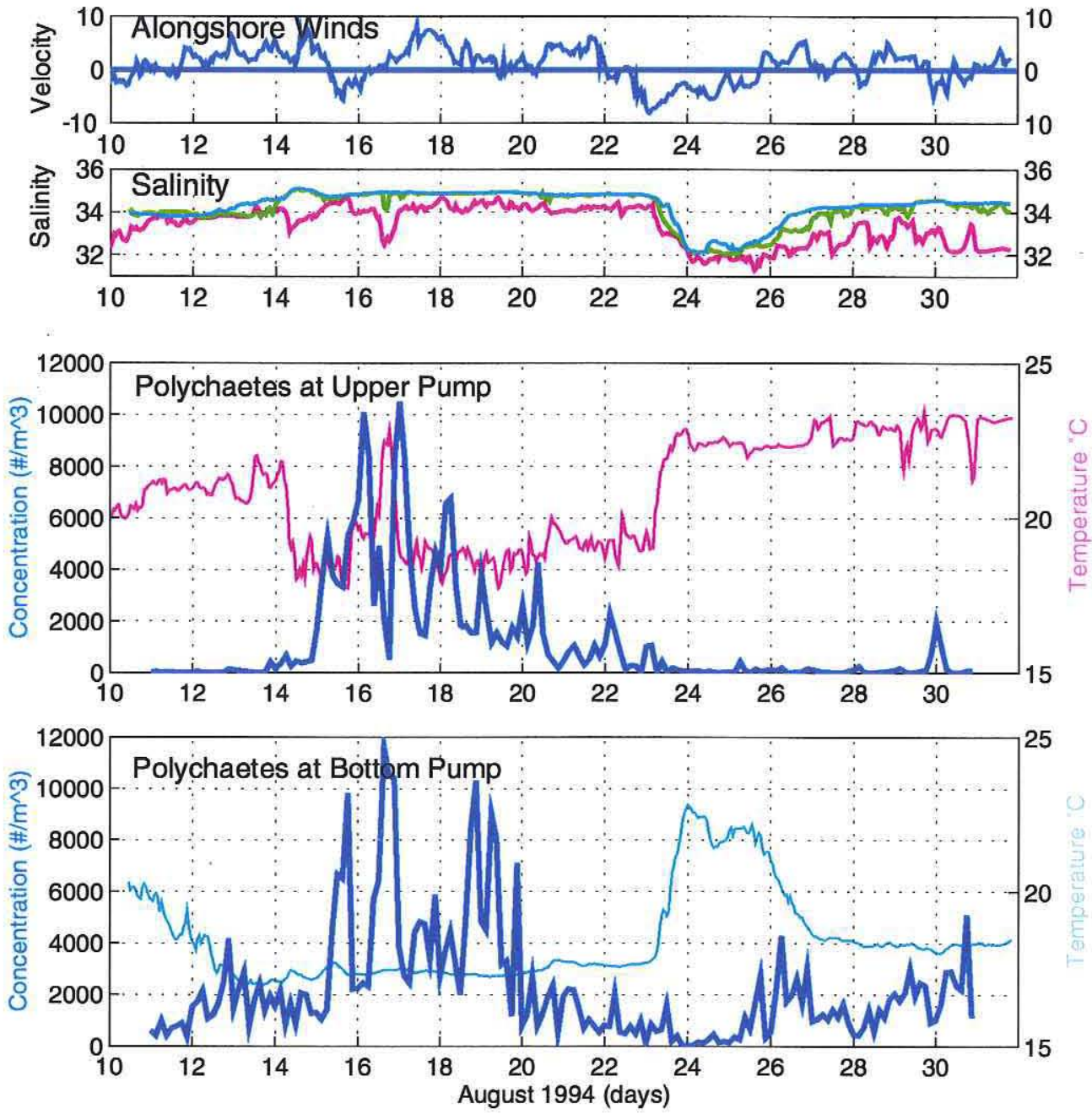

Figure 3.4 Time series of larval concentrations (bold lines, bottom panels) for polychaetes at the upper and bottom pumps, with water temperature near each pump (thin line) super-imposed on each figure. Alongshore component of wind velocity and salinity conditions are shown in the upper two panels. Refer to Fig. 3.3 for convention of color-coding. 

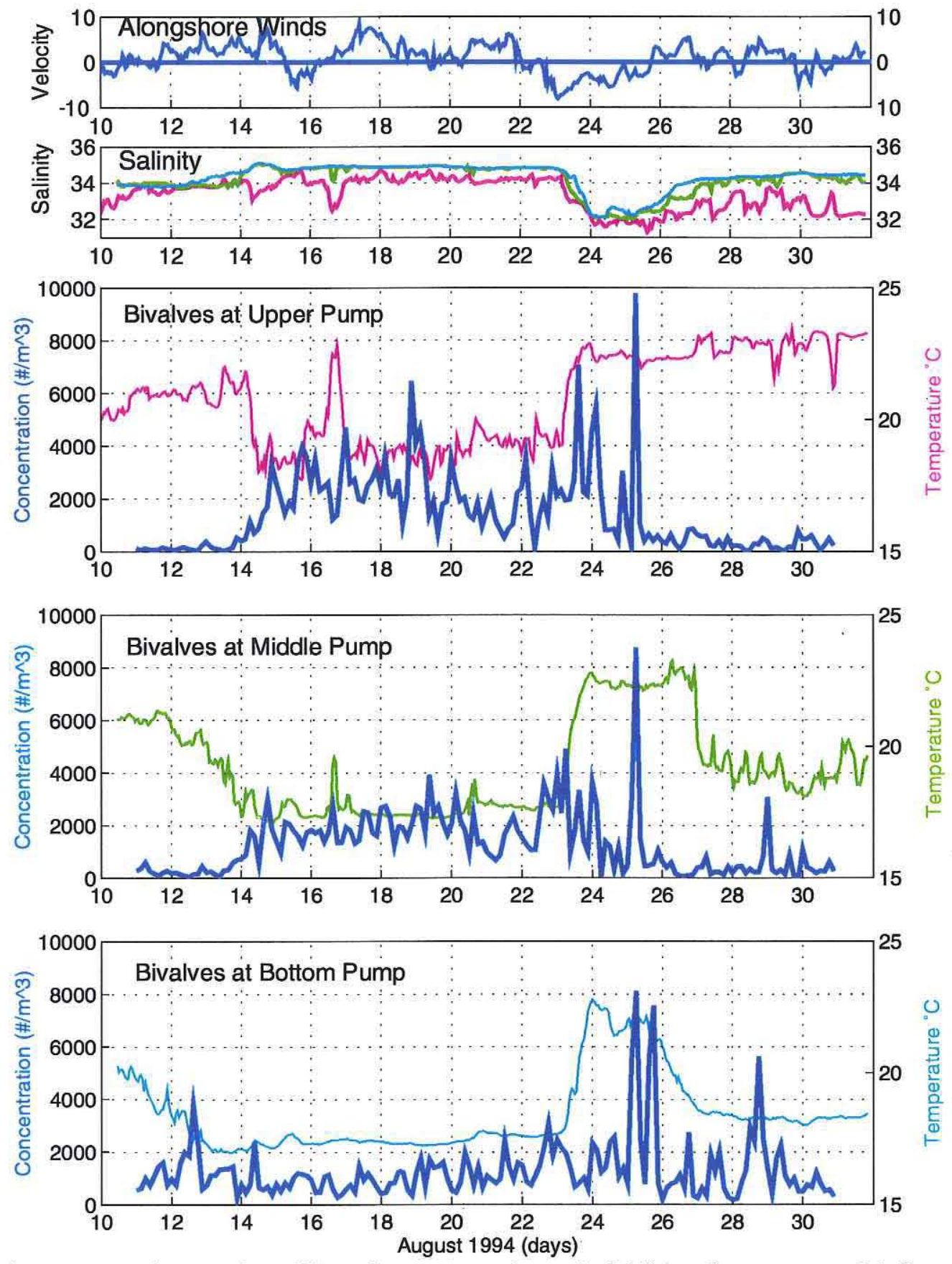

Figure 3.5 Time series of larval concentrations (bold lines, bottom panels) for bivalves at the upper, middle and bottom pumps, with water temperature near each pump (thin line) superimposed on each figure. Alongshore component of wind velocity and salinity conditions are shown in the upper two panels. Five plankton samples (August 21 at 0300, 1500 and 2100; August 22 at 0000 and 1200 $\mathrm{hr}$ ) collected by the middle pump were damaged during recovery and processing; interpolated values were used in these five cases. Refer to Fig. 3.3 for convention of color-coding. 

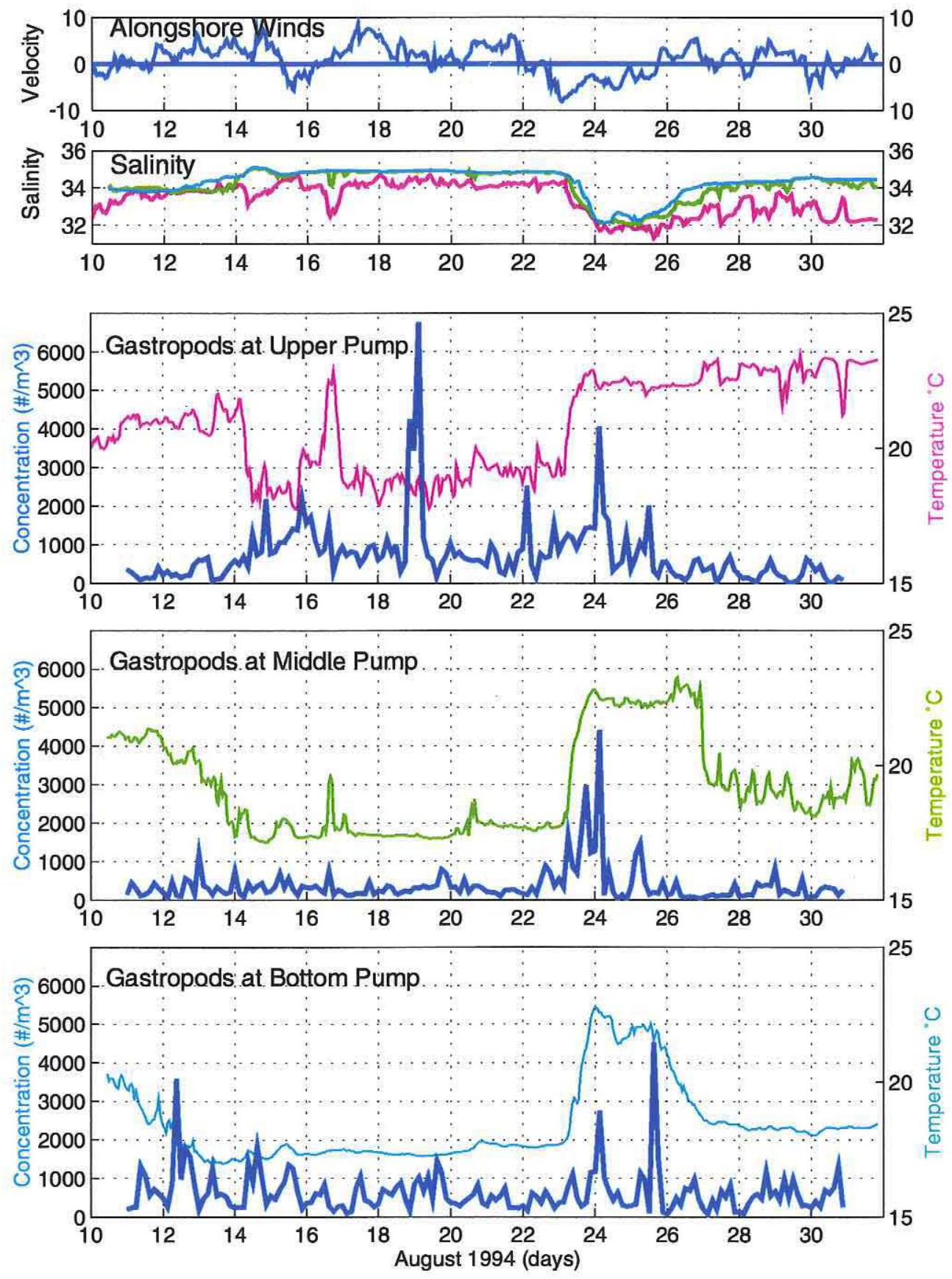

Figure 3.6 Time series of larval concentrations (bold lines, bottom panels) for gastropods at the upper, middle and bottom pumps, with water temperature near each pump (thin line) superimposed on each figure. Alongshore component of wind velocity and salinity conditions are shown in the upper two panels. Five plankton samples (August 21 at 0300, 1500 and 2100; August 22 at 0000 and $1200 \mathrm{hr}$ ) collected by the middle pump were damaged during recovery and processing; interpolated values were used in these five cases. Refer to Fig. 3.3 for convention of color-coding. 

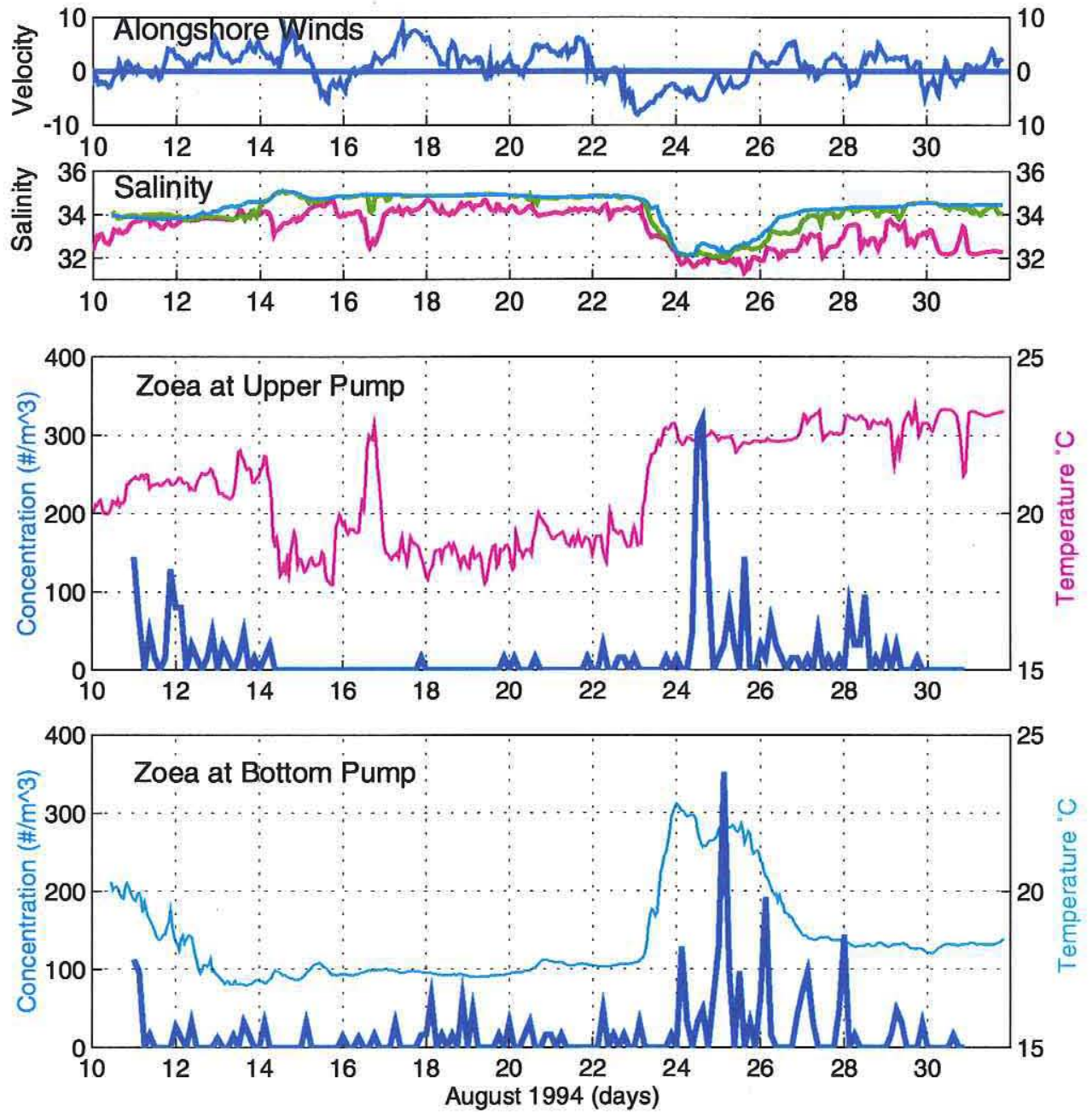

Figure 3.7 Time series of larval concentrations (bold lines, bottom panels) for zoea at the upper and bottom pumps, with water temperature near each pump (thin line) superimposed on each figure. Alongshore component of wind velocity and salinity conditions are shown in the upper two panels. Refer to Fig. 3.3 for convention of color-coding. 
larval concentration changed over an order of magnitude, and sometimes over two orders of magnitude, in as little as 3-6 hours. Two dominant modes of decorrelation times (Table 3.2) where quantified through autocorrelation analysis: one associated with the synoptic meteorological time scale (of order 2-5 days) and the other with responses occurring in 1 day or less.

\subsubsection{Temporal Variations and Vertical Patterns}

Temporal variations and corresponding changes in vertical structure of larval concentration were evaluated within the context of two major sources of variability in the data: a relatively "low-frequency" (of order several days) source of variability and a "high-frequency" (of order $\leq 1$ day) source of variability. In analyzing these sources of variability, four assumptions were made.

First, both high- and low-frequency temporal variations in larval concentration are assumed to result from advection of spatial patches or from larval behaviors, but not from local events, such as spawning of larvae right below pumps or local resuspension. This assumption is supported by the fact that early-stage larvae (e.g., trochophores and other early-stage larvae $<100 \mu \mathrm{m}$ ) were excluded from the analysis, and because near-bottom suspended sediment concentrations and currents indicate that upward mixing of larvaesized particles typically did not extend beyond $30 \mathrm{~cm}$ above the bed (C. Friedrichs, pers. comm.). Near-bottom shear velocities due to waves $\left(\mathrm{u} *_{\mathrm{sf}}\right)$ showed two periods (August 14-16 and 22-24) when silt, fine sand, and larvae could have been lifted off the bottom (L.D. Wright, unpubl. data; Fig. 3.3). During the first period, $u_{* f}\left(\sim 0.8 \mathrm{~cm} \mathrm{sec}^{-1}\right)$ may 
Table 3.2 Decorrelation times for larval concentration and physical time-series data. Decorrelation times were determined by the time point where the autocorrelation function crossed the $\mathrm{x}$-axis. The series mean was removed from a time series prior to analysis.

\begin{tabular}{|l|l|}
\hline Variable \& Depth & Decorrelation Time \\
\hline Polychaetes - Upper & 3.125 days $^{\text {a }}$ \\
\hline Polychaetes - Bottom & 3.625 days $^{\mathrm{a}}$ \\
\hline Gastropods - Upper & 2.25 days $^{\text {a }}$ \\
\hline Gastropods - Middle & 1.5 days \\
\hline Gastropods - Bottom & $6 \mathrm{hr}$ \\
\hline Bivalves - Upper & 2.375 days $^{\text {a }}$ \\
\hline Bivalves - Middle & 2.875 days $^{\mathrm{a}}$ \\
\hline Bivalves - Bottom & $15 \mathrm{hr}$ \\
\hline Zoea - Upper & 1.125 days \\
\hline Zoea - Bottom & 9 hr \\
\hline & \\
\hline Alongshore Wind Velocity & $\sim 1$ day \\
\hline Water Temperature & $\sim 3$ days \\
\hline Salinity & $\sim 3$ days \\
\hline bensity & $\sim 3$ days \\
\hline Alongshore Currents & $\sim 3$ days \\
\hline Cross-Shore Currents & $\sim 6$ hr -1 day $^{\mathrm{b}}$ \\
\hline
\end{tabular}

a depths where the majority of larvae were collected

${ }^{b}$ decorrelation times for physical variables were of the same order at the three depths 
have approached the critical velocity $\left(0.8-1.2 \mathrm{~cm} \mathrm{sec}^{-1}\right)$ required to lift these sediments off the bottom, but the current shear velocities $\left(u *_{c} \sim 0.53 \mathrm{~cm} \mathrm{sec}^{-1}\right)$ were not strong enough to keep the sediment in suspension above the wave boundary-layer $(\sim 5-10 \mathrm{~cm}$ at the site; C. Friedrichs, pers. comm.). During the second period, $\mathrm{u}_{\mathrm{sf}}$ and $\mathrm{u}_{\mathrm{*}_{\mathrm{c}}}$ were both relatively high $\left(\sim 1.5-1.8 \mathrm{~cm} \mathrm{sec}^{-1}\right.$; Fig. 3.3$)$ corresponding to a time when wave heights were also large. Suspended sediment concentrations at the bottom pump (3.2 mab) during this period were predicted by fitting a power curve to the observed suspended sediment concentrations within $1 \mathrm{~m}$ of the bed. The extrapolated value $(0.024 \mathrm{~g} / \mathrm{liter})$ for the period of intense resuspension suggests that low concentrations of resuspended particles were present at the depth of the bottom pump. Thus, locally resuspended settled larvae may have been collected by the bottom pump during the period from August 22 24.

Second, contributions to variations in larval concentrations are assumed, in most cases, to result from cross-shelf (versus alongshore) advection of water masses containing larvae. Contributions from alongshore sources have been considered negligible except during strong downwelling conditions. Implicit in this assumption is another assumption of large-scale alongshore homogeneity, which is necessary because the alongshore current speeds are greater than the speeds of cross-shelf flow by up to an order of magnitude. Large-scale alongshore homogeneity is supported by the fact that most invertebrate species present at the site have adult ranges from south of Cape Hatteras, NC to north of Cape Cod, MA (Gosner 1979). Spawning events along the coast may be 
synchronized by temperature changes that are often coherent over large portions of the coast due to wind-driven cross-shelf movements of the thermocline. Moreover, larval concentration and temperature time series exhibit similar variations (see following section); and, given the fact temperature variations are largely due to the cross-shelf advection of the thermocline (refer to section 3.3), variations in larval concentration are likely to result from cross-shelf movement of water masses containing larvae.

Third, in assessing larval associations with particular local water masses, it was assumed that local water masses at this inner-shelf site could be distinguished according to their temperature-salinity characteristics (Fig. 3.8), and that these characteristics were conserved throughout advective events. During August 1994 the heat content of the water column changed before and after downwelling wind events, indicating that mixing processes did not play a large role during the study period (Austin 1998, 1999) and that temperature changes resulted primarily from advection.

Fourth, in analyzing high-frequency sources of variation that potentially involve larval behavior (e.g., diel vertical migration), it was assumed that the clearest signal would be seen during a period in which larval concentrations were high, the assemblage of species present was expected to be fairly constant, and the physical conditions were relatively uniform. Thus, the extent of diurnal forcing in each of the larval time series was assessed during carefully chosen periods that met these conditions. A 9-day period of cool water (August 14-22) was chosen for evaluation of diurnal forcing in larval polychaetes, bivalves and gastropods; and a 6-day period of warmer water (August 2429) was chosen for zoea. 


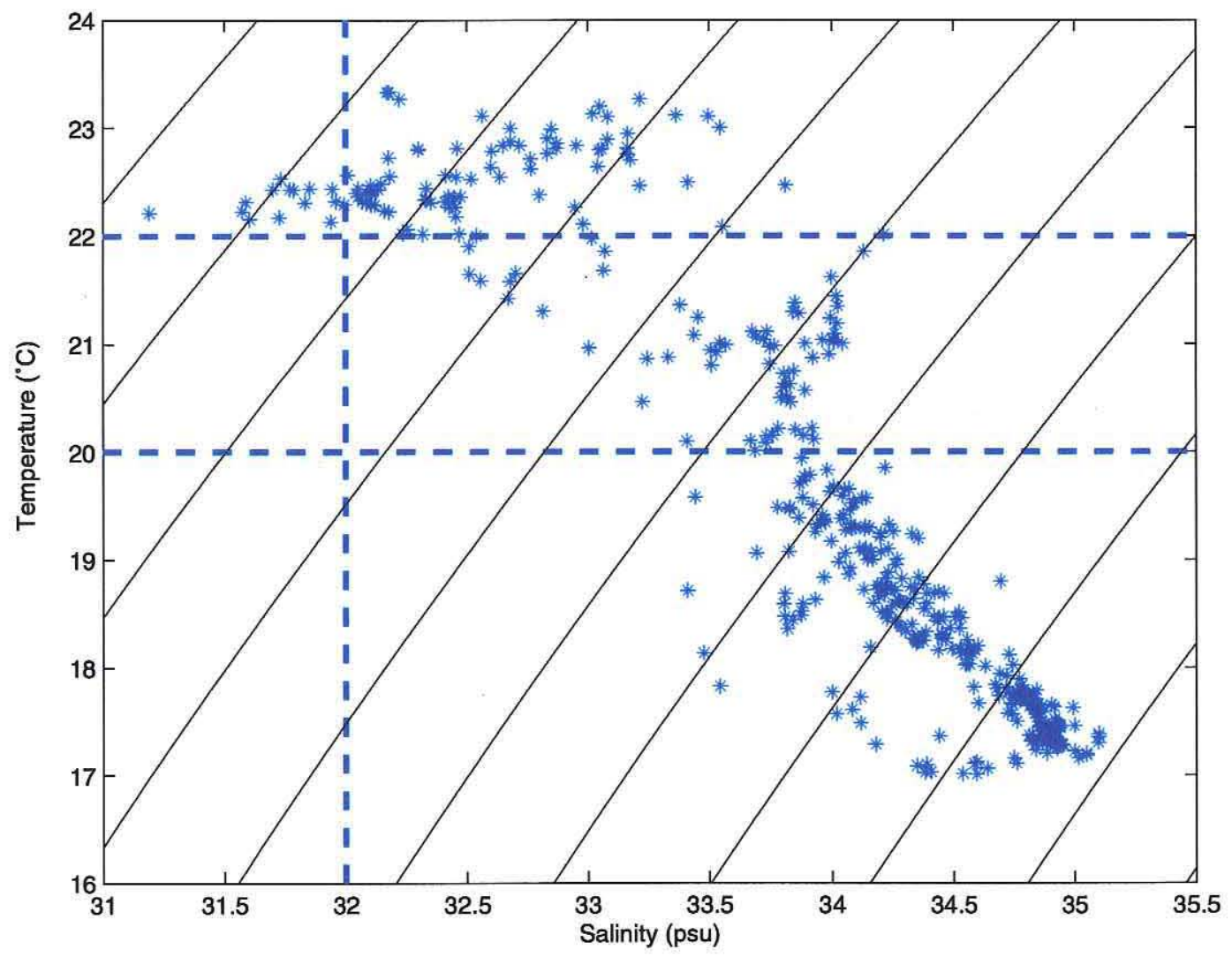

Figure 3.8 Temperature-Salinity Diagram for the 20-m site, August 1994 based on the hydrographic conditions at the depths of the three plankton pumps. Clustering of points reflects two main local water masses: a cooler, more-saline water mass below the thermocline (below the lower horizontal line), and a warmer, less-saline water mass above the thermocline (above the upper horizontal line). Temperatures associated with the thermocline were reported by Waldorf et al. (1997). Water masses associated with the Chesapeake Bay Plume (<32 psu; vertical line; as reported by Rennie et al. 1999) were not clearly defined at the depths of the three plankton pumps. Curves of equal density are illustrated in black; each line represents 0.5 sigma-t units. 
During these evaluation periods, no diurnal or semidiurnal periodicities were found in either temperature or cross-shelf current velocity data from the depths where larval samples were collected. This finding suggests negligible influence of physical processes, such as diurnal heating/cooling or internal tides, at the depths where larval samples were taken. Thus, diurnal patterns observed during those periods likely involved diel larval behaviors.

\section{Larval Polychaete Concentration Time Series (enumerated at the upper and bottom}

pumps only): Polychaete larvae at both depths (upper and bottom pumps) showed very similar patterns (Fig. 3.4) of increased abundances (of order 1000's to 10,000) over a several day period (August $15-20)$ in which water temperature was low $\left(<19^{\circ} \mathrm{C}\right)$ and salinity was high ( $>34 \mathrm{psu}$ ). Cool water had been advected to the site during upwelling conditions. Despite the conspicuous high-frequency variations, concentrations were, on average, higher during this period by $1-2$ orders of magnitude. Concentrations were low (of order $0-100$ 's) during downwelling periods when warm water had been advected to the site. The association between larval polychaetes and specific water temperatures appeared to be stronger than their association with salty or more-dense water because they were not found in the upper pump during periods of warm $\left(\sim 21^{\circ} \mathrm{C}\right)$, salty $(\sim 34 \mathrm{psu})$ water at the start of the time series (August 11-15).

Despite the strong apparent association between larval polychaetes and water mass characteristics, the cross-correlations between polychaete concentration and temperature, salinity or density were not statistically significant. This lack of statistical 
significance was partly due to the low-frequency response of polychaete concentration, temperature, salinity and density time series; few independent realizations of the upwelling and downwelling conditions occurred during this 3-wk study. Thus, to examine further the relationship between larval distribution and water mass characteristics, concentrations of larval polychaetes collected at all sampling depths were combined and plotted as a function of temperature and salinity (Fig. 3.9; hereafter referred to as a Temperature-Salinity-Plankton diagram, or T-S-P plot; Barry 1959, 1963, 1964; Bradshaw 1959; Michel and Foyo 1976; Sameoto 1984). The T-S-P plot indicates that polychaete larvae were clustered as a single group associated with cool, salty water. Of the total vertical population of polychaete larvae sampled, $92 \%$ were collected in cooler water below the thermocline, whereas $2 \%$ were collected in warm water above the thermocline

The time series of polychaete concentration at the upper pump exhibited similar patterns to the time series of polychaete concentration at the bottom pump, indicating that polycheate larvae were distributed throughout this depth interval, over relatively long times. Yet, some obvious differences were observed, and were associated with differences in temperature between the two depths. For example, concentration was higher initially (August 11-15) and also later (August 26-31) in the series from the bottom pump as compared to the series from the upper pump. During these periods, bottom waters had cooled $\left(<19^{\circ} \mathrm{C}\right)$ upon relaxation of downwelling, but the surface waters $\left(>21^{\circ} \mathrm{C}\right.$ ) had not yet responded. A large decrease in concentration (August 16) at the top pump corresponded with an episodic event when the upper pump sampled briefly 


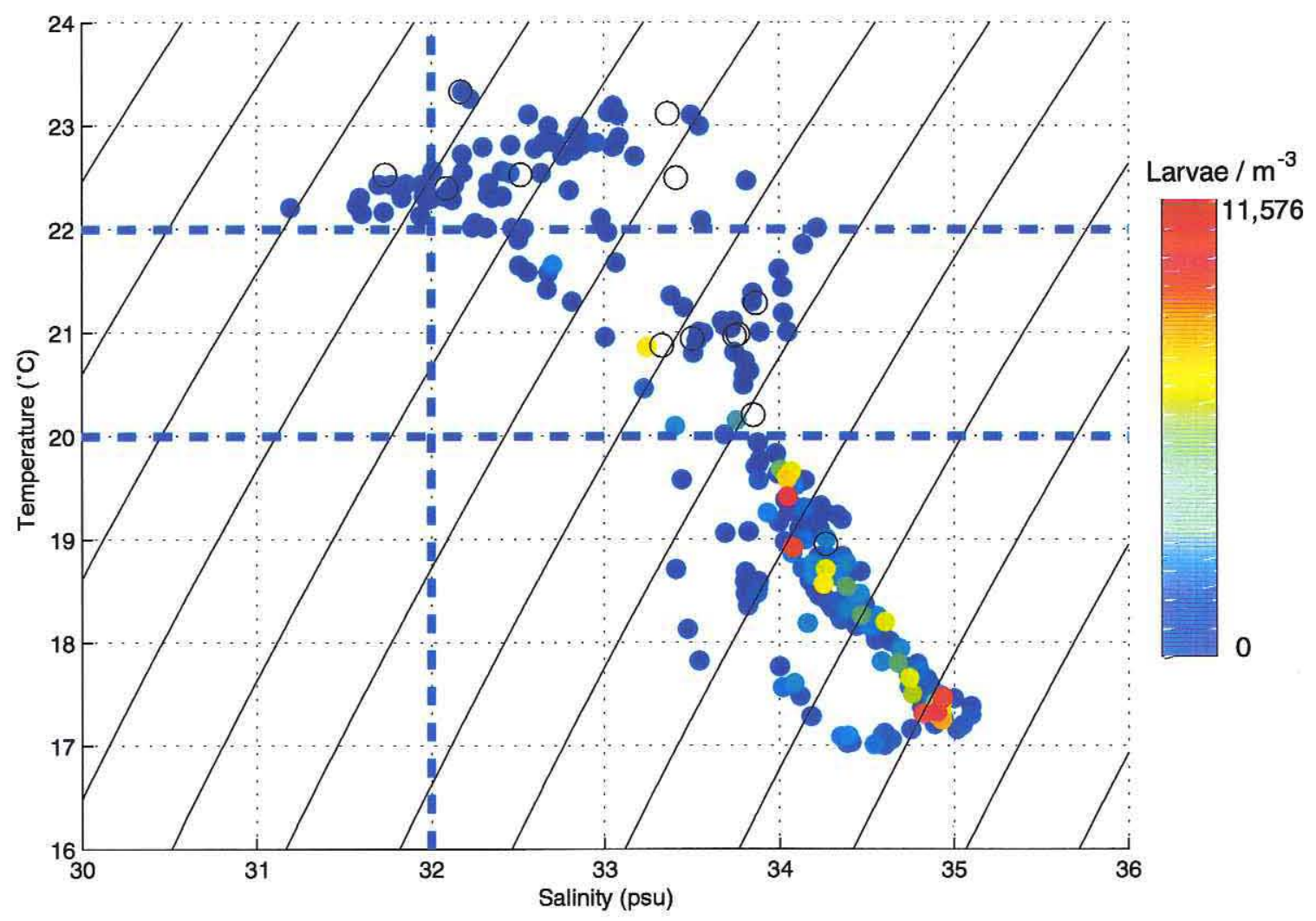

Figure 3.9 Temperature-Salinity-Plankton (T-S-P) plot for polychaete larvae. Larval concentration is plotted as a function of temperature and salinity. Relative larval concentrations are shown in color (maximum in red and minimum in blue) and are scaled to the range of the data $\left(0-11,576 / \mathrm{m}^{\wedge} 3\right)$. Refer to Fig. 3.8 for explanation of blue dashed lines and black contours. Note clustering of high larval concentrations below the thermocline. Open circles represent 0 larvae/ $\mathrm{m}^{\wedge} 3$. Plot based on 320 larval samples. 
in the warmer water $\left(>20^{\circ} \mathrm{C}\right)$ within or above the thermocline. Not all lowconcentration measurements corresponded with sampling above the thermocline, however, suggesting spatial heterogeneity within a larval patch or the influence of higherfrequency (e.g., diurnal) processes.

Diurnal changes in the vertical distribution of polychaete larvae were observed in the concentration time series (Fig. 3.10), and accounted for the majority of the high frequency (of order $\leq 1$ day) variability during the evaluation period. The polychaete concentration time series from both the upper and bottom pumps exhibited a statistically significant and distinct increase in autocorrelation at a 24-hr lag (Fig. 3.11), suggestive of diurnal forcing. In the absence of diurnal physical forcing, diel vertical migration is assumed. The larval time series at the upper and bottom pumps were $12 \mathrm{hr}$ out of phase $(\mathrm{r}=0.546$ at a 12-hr lag, $\mathrm{p}<0.05)$, suggesting larval migration between these two depths during the evaluation period. Furthermore, of the total polychaetes collected at the upper pump, $67 \%$ occurred in night samples and $33 \%$ in day samples. Together, these results suggest a diel migration pattern of nocturnal ascent and daytime descent.

\section{Larval Bivalve Concentration Time Series (enumerated at the upper, middle and}

bottom pumps): A low-frequency increase (of order 100's to 1000's) in concentration of bivalve larvae (Fig. 3.5), associated with colder $\left(<19^{\circ} \mathrm{C}\right)$ more saline $(>34 \mathrm{psu})$ water, was observed only at the depths of the upper and middle pumps. Concentrations were generally low (of order $0-100$ 's) during periods of warm water at the upper and middle 

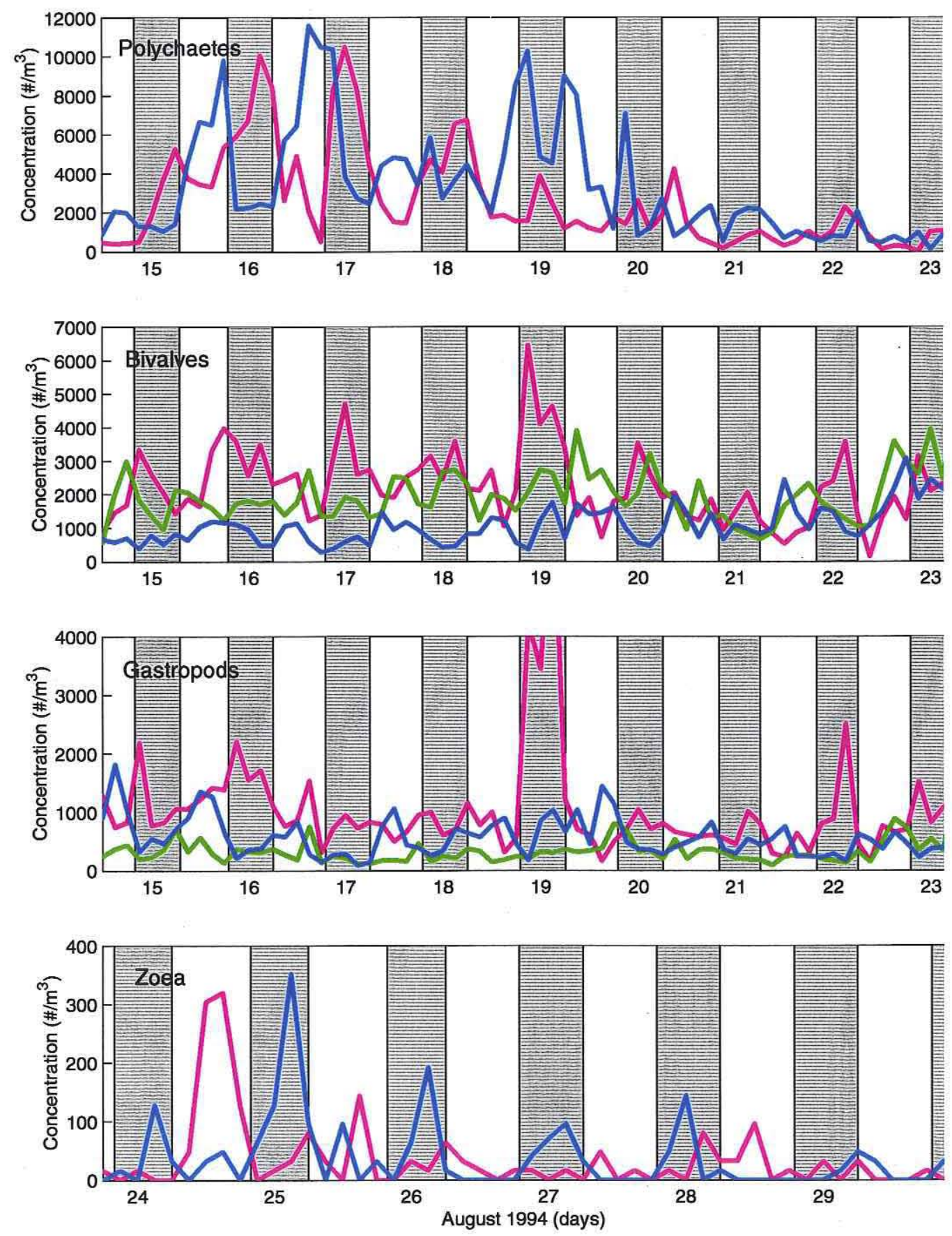

Figure 3.10 Larval concentration time series for individual larval groups with night time shaded in gray. Concentration time series for the upper pump is shown in magenta, for the middle pump is shown in green, and for the bottom pump is shown in blue. Short-wave radiation values less than 50 Watts $/ \mathrm{m}^{\wedge} 2$ were used to delineate night time periods. 

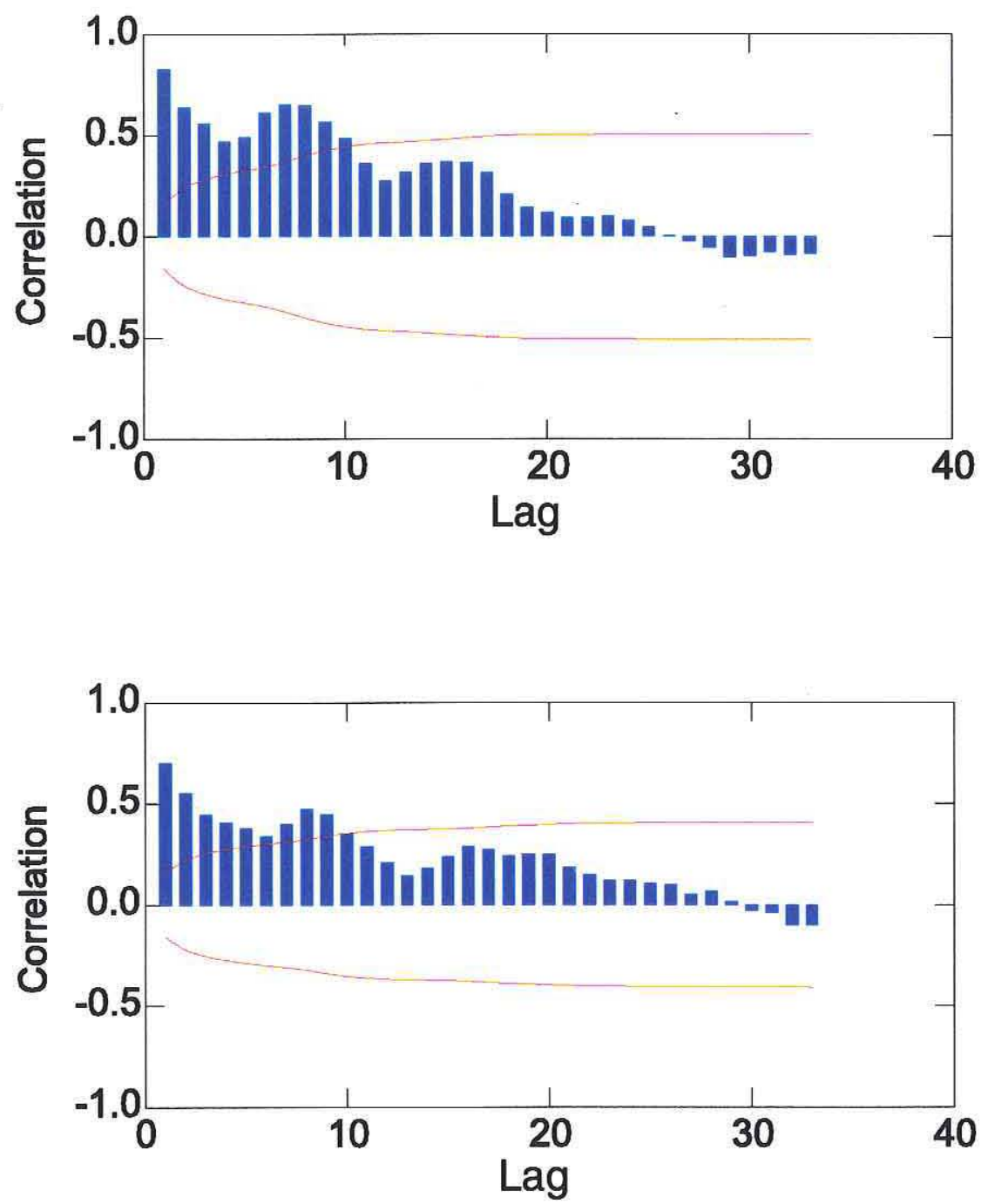

Figure 3.11 Autocorrelation functions for time series of polychaete concentrations at the upper (a) and bottom (b) pumps. The length of each bar indicates the size of the correlation at each $3-\mathrm{hr}$ lag, and the dotted horizontal curves give $95 \%$ confidence intervals. The time point where the the autocorrelation function crosses the $\mathrm{x}$-axis $(y=0)$ indicates the decorrelation time scale of the series. Distinct and significant increases in autocorrelation are seen at $24-\mathrm{hr}(\mathrm{lag}=8)$. 
pumps (e.g., August 11-14 and 26-30); however, peaks in concentration observed during a period of warm, less-saline water associated with strong downwelling conditions (August 24-26) were an exception to this general pattern. Relatively low concentrations were recorded during upwelling conditions when the upper pump sampled above the thermocline (e.g., August 16). Concentrations were generally lower at the bottom pump, except during strong downwelling conditions.

Comparing bivalve concentrations at the upper and middle pumps, the time series were significantly correlated $(r=0.703, p<0.05)$ over the entire study period, whereas those at the middle and bottom pumps were not correlated. This result implies a vertical distribution of increased concentration extending below the depth of the upper pump by over $3.5 \mathrm{~m}$ (the distance to the middle pump), but less than $9 \mathrm{~m}$ (the distance to the bottom pump). Thus, bivalves appeared to be located higher in the water column, but below the thermocline, and concentrated in a tighter vertical band than the polychaetes.

Despite the strong pattern of increased abundance during periods of cool upwelled water, bivalve larvae also occurred in warm $\left(<22^{\circ} \mathrm{C}\right)$, less-saline $(\sim 32 \mathrm{psu})$ water. At the three pumps, asynchronous and synchronous (August 25 at 06:00 hr) peaks in larval bivalve concentration were observed during a period of strong downwelling conditions. Bivalve concentrations during the synchronous peaks were $9780 \mathrm{~m}^{-3}$ at the upper pump, $8756 \mathrm{~m}^{-3}$ at the middle pump, and $8108 \mathrm{~m}^{-3}$ at the bottom pump, and salinities were 31.8 , 32.0 and 32.2 psu, respectively. At the surface, salinity was 30.2 psu. Furthermore, the bivalve larvae contained within these peak concentrations appear to have stronger 
associations with less-saline water than with specific water temperatures because similar peaks in concentration were not found during periods of warm $\left(\sim 21^{\circ} \mathrm{C}\right)$, salty $(\sim 34 \mathrm{psu})$ water at the start (August 11-15) of the time series or during the warm-water period (August 26-31 at the upper pump) at the end of the series. This association with warm, less-saline water is different than the association with cool, salty water observed within the same bivalve grouping. The T-S-P plot of larval bivalve concentrations (Fig. 3.12) identified one cluster of concentrated bivalve larvae associated with cool, salty water ( $73 \%$ of the total vertical population of bivalve larvae), and a second cluster associated with warm, less-saline water (18.3\% of the total vertical population of bivalve larvae). Therefore, the statistically non-significant cross-correlation between bivalve concentration and temperature or salinity was partly due to the presence of two subgroups, each associated with different water masses.

Concentration time series of samples collected at the middle pump with increased taxonomic resolution (Fig 3.13) indicated that some groups of bivalves (e.g., Ensis directus, Pholadidae, and Spisula/Mercenaria larvae) were more abundant during periods of cooler upwelled water (August 15-20), and were substantially less abundant during the warm water event (August 24-26) when salinities were low. No consistent patterns were found for Anadara spp. and Tellina spp. Of the five species or species-groups identified, none had peaks in concentration exclusively during the period of warm, less-saline water (August 24-26). Tellina had peaks in concentration in both warm/less-saline water and $\mathrm{cool} / \mathrm{salty}$ water, but the maximal peak in concentration that occurred during the warmwater downwelling event was about one tenth the concentration of total bivalves 


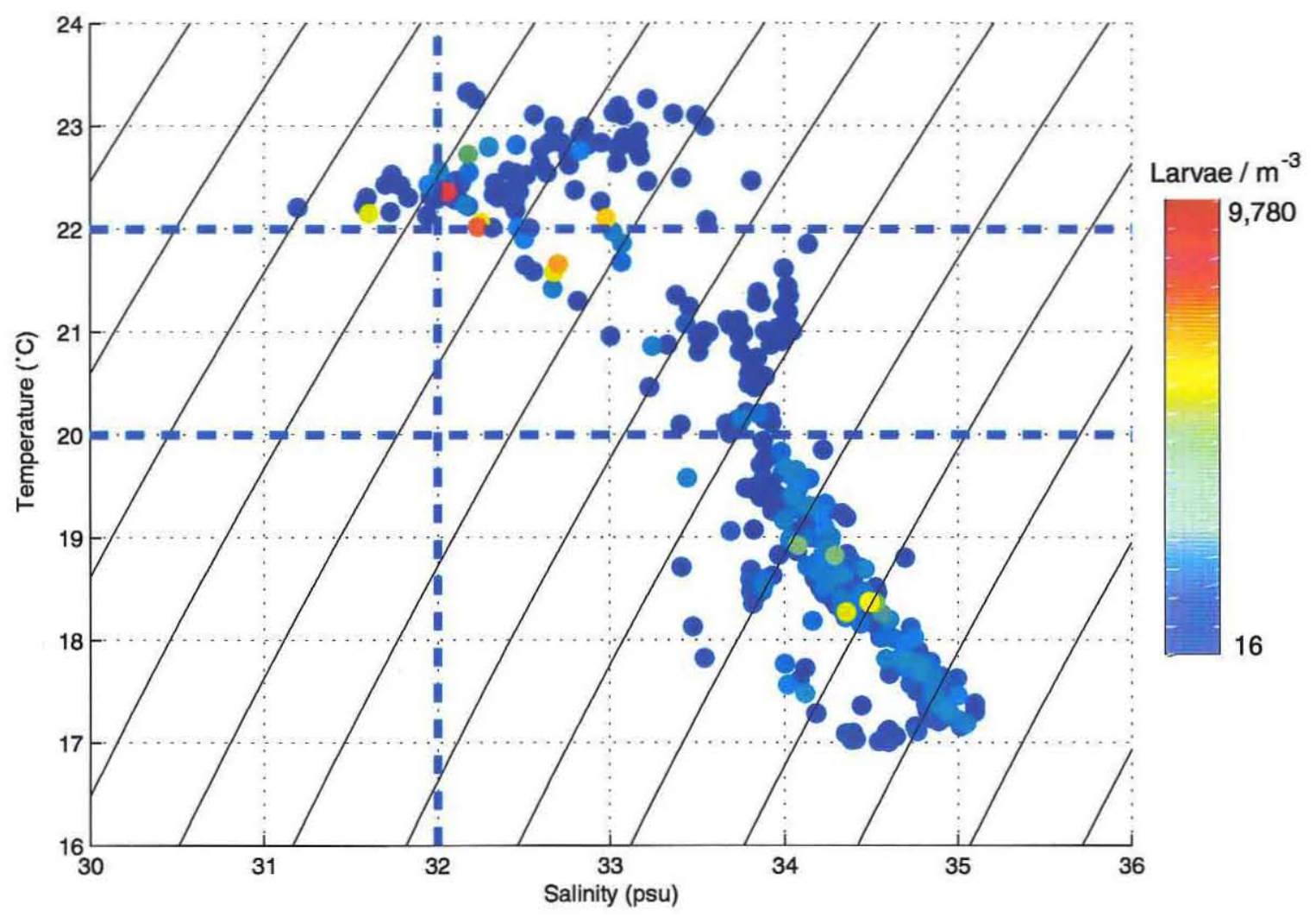

Figure 3.12 Temperature-Salinity-Plankton (T-S-P) plot for bivalve larvae. Larval concentration is plotted as a function of temperature and salinity. Relative larval concentrations are shown in color (maximum in red and minimum in blue) and are scaled to the range of the data $\left(16-9,780 / \mathrm{m}^{\wedge} 3\right)$. Refer to Fig. 3.8 for explanation of blue dashed lines and black contours. Note two clusters of high larval concentrations above and below the thermocline. Plot based on 480 larval samples. 

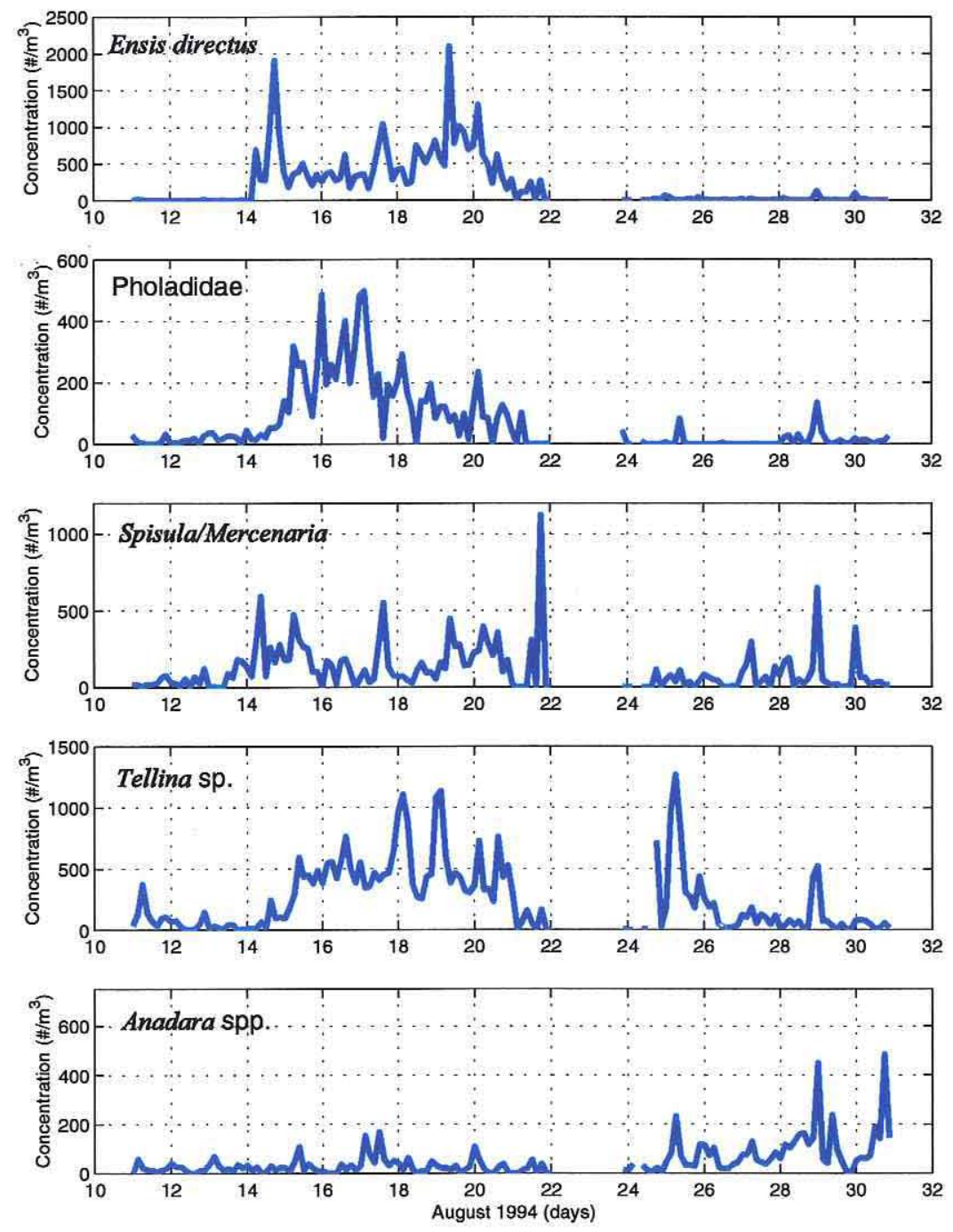

Figure 3.13 Time series of larval concentration for Ensis directus, Pholadidae, Spisula/Mercearia spp., Tellina spp., and Anadara spp. The morphological damage resulting from the techniques used to collect and preserve the larval samples rendered some bivalves beyond recognition as species, and impacted between $10 \%$ and $100 \%$ of each sample. Because the percentage of identifiable species in the non-crushed fractions does not necessarily represent the same percentage of that species in the crushed fractions (i.e., crushing problems may be species-specific and not random), species data were not used for quantitative analyses. However, similar trends were observed in the species data whether or not the crushing problem was species-specific. Concentration shown indicates total concentration, assuming species were found in crushed and identifiable fractions in equal proportions. No species data were recorded between August 22 at 03:00 $\mathrm{hr}$ and August 23 at 21:00 hr. 
observed during that period. Thus, other unidentified bivalve groups must have contributed to the large peak in larval concentration during the strong downwelling conditions. These results, combined with the T-S-P plot (Fig. 3.12), offer compelling evidence that at least two sub-groups of bivalve larvae were collected, each associated with a different water mass.

High-frequency diurnal variations were also observed in larval bivalve concentration time series (Fig. 3.10). The time series from the upper and bottom pumps exhibited a statistically significant and distinct increase in autocorrelation at a 24-hr lag, indicative of diurnal forcing. Cross-correlations between bivalve concentration time series at the upper pump and short-wave radiation indicated a significant negative correlation at 0 lag $(\mathrm{r}=-0.485, \mathrm{p}<.01)$ and a significant positive correlation at 12-hr lags $(\mathrm{r}=0.331, \mathrm{p}<0.05)$. These results indicate that the larval concentration and light-level time series were $12 \mathrm{hr}$ out of phase, and that concentrations decreased when light levels increased. For the upper pump, $62 \%$ of the bivalve larvae were collected at night. These results suggest a diel migration pattern of nocturnal ascent and daytime descent, like the polychaetes. The cross-correlations were not statistically significant between bivalve concentration time series at the upper pump and concentration time series at either the middle or bottom pumps, implying either low-amplitude migrations or that only a fraction of the bivalve larvae at the middle and bottom pumps was migrating. 


\section{Larval Gastropod Concentration Time Series (enumerated at the upper, middle and}

bottom pumps): Larval gastropod concentration time series exhibited patterns similar to the larval bivalve concentration time series. In fact, the correlations between bivalve and gastropod concentration time series were statistically significant at both the upper and bottom pumps. Gastropod larvae were more concentrated (of order 100's to 1000's) near the upper pump during periods of $\operatorname{cool}\left(<19^{\circ} \mathrm{C}\right)$ water and relatively less concentrated (of order 0 to 100's) during periods of warm water (e.g., August 11-14 and 26-30; Fig. 3.6). Peaks in concentration, observed during a period of warm, less-saline water (August 24-26) associated with strong downwelling conditions, were an exception to this general pattern. Concentrations were low (of order 0 to 100's) at the middle pump throughout the period of cool water, and relatively high (of order 100's to 1000's) at the bottom during all conditions. These results suggest that the majority of gastropods in cool upwelled water masses were more concentrated just below the thermocline, in a tighter vertical band than the bivalves, and that a second concentrated region existed near the bottom.

At all three pumps during a period of intense downwelling, asynchronous and synchronous (August 24 at 03:00 hr) peaks in concentration of larval gastropods were observed in warm $\left(<22{ }^{\circ} \mathrm{C}\right)$, less-saline $(\sim 32 \mathrm{psu})$ water. Furthermore, peaks occurred close in time to the advance and retreat of the downwelled thermocline. Larval concentrations during the synchronous peaks were $4,050 \mathrm{~m}^{-3}$ at the upper pump, 4,416 $\mathrm{m}^{-3}$ at the middle pump, and $2,760 \mathrm{~m}^{-3}$ at the bottom pump, and salinities were $31.6,32.0$ and 32.2 psu, respectively. At the surface, salinity was $30.6 \mathrm{psu}$. The association of the 
gastropod larvae collected during this period appears to be stronger with less-saline water than with specific water temperatures because similar peaks in gastropod concentration were not found during periods of warm $\left(\sim 21^{\circ} \mathrm{C}\right)$, salty $(\sim 34 \mathrm{psu})$ water at the start of the time series (August 11-15) or during the warm-water period at the end of the series (August 26-31 at the upper pump).

The T-S-P plot of larval gastropod concentrations (Fig. 3.14) indicated one cluster of concentrated gastropod larvae associated with cool, salty sub-thermocline water $(67 \%$ of the total vertical population of gastropod larvae), and a second cluster associated with warm, less-saline water ( $22 \%$ of the total vertical population of gastropod larvae). Although the T-S-P plot did not separate the two below-thermocline sub-groups (i.e., the near-thermocline and near-bottom sub-groups), these results, together with the vertical distributions identified in the concentration time series (Fig. 3.6), suggest that 3 subgroups of gastropods were sampled. One sub-group tracked below but close to the thermocline, a second sub-group tracked above the thermocline in warm, less-saline water, and a third sub-group was associated with the bottom.

High-frequency diurnal variations in vertical distributions were also observed in the time series of larval gastropod concentration (Fig. 3.10). Gastropod concentration time series at the upper and bottom pumps showed statistically significant and distinct increases in autocorrelation at a lag of $24 \mathrm{hr}$. A diurnal cycle was not observed at the middle pump depth, where larval concentrations were generally low (Fig. 3.10). At the bottom pump, gastropod concentration time series and time series of short-wave radiation were statistically negatively correlated $(r=-0.382, \mathrm{p}<0.05)$ at a lag of $-12 \mathrm{hr}$, indicating 


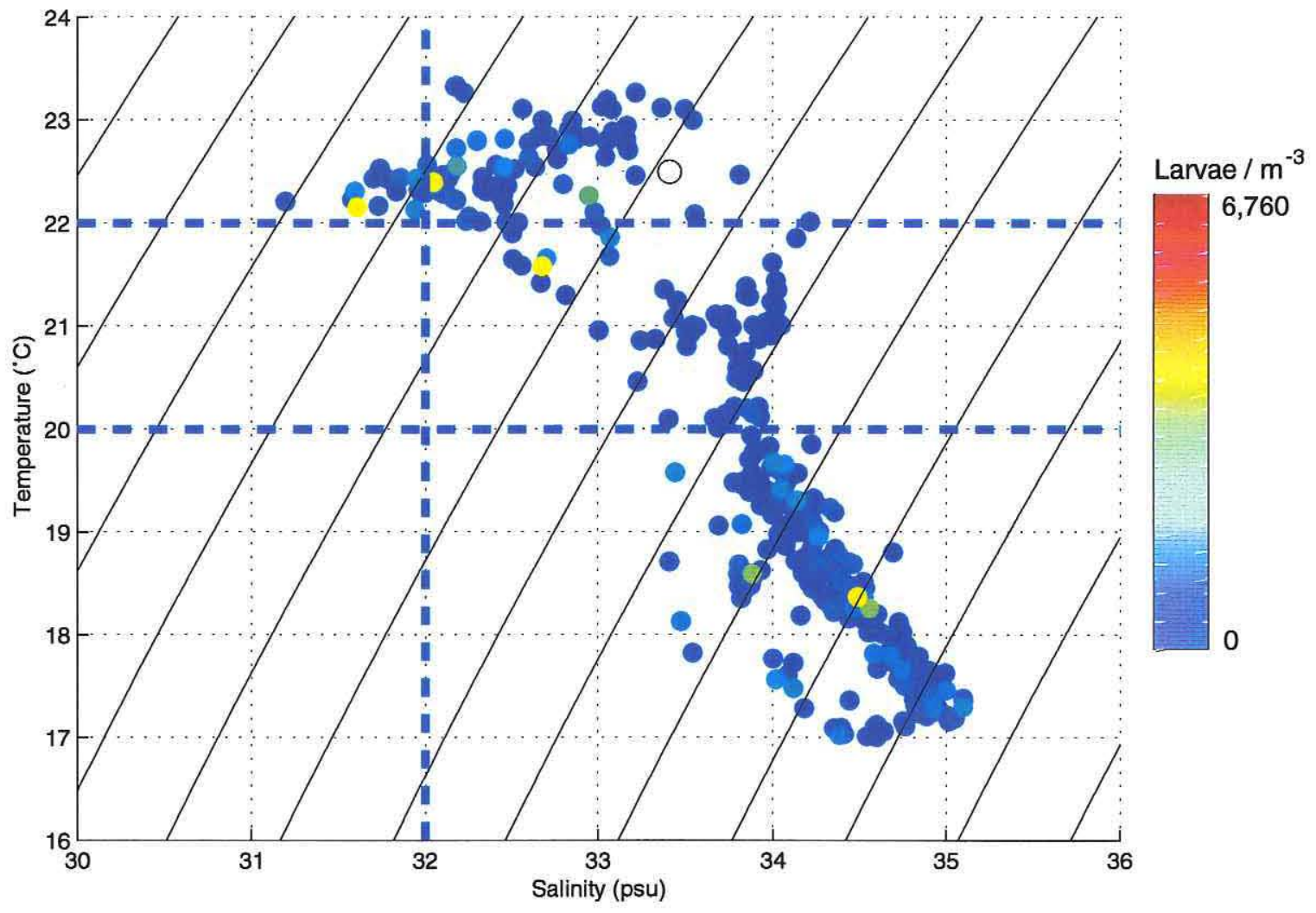

Figure 3.14 Temperature-Salinity-Plankton (T-S-P) plot for gastropod larvae. Larval concentration is plotted as a function of temperature and salinity. Relative larval concentrations are shown in color (maximum in red and minimum in blue) and are scaled to the range of the data $\left(0-6,760 / \mathrm{m}^{\wedge} 3\right)$. Refer to Fig. 3.8 for explanation of blue dashed lines and black contours. Note two clusters of high larval concentrations above and below the thermocline. Open circles represent 0 larvae $/ \mathrm{m}^{\wedge} 3$. Plot based on 480 larval samples. 
that gastropod concentrations decreased at this depth during the night. Moreover, the cross-correlation between gastropod concentrations at the upper and bottom pumps showed a significant positive correlation $(\mathrm{r}=0.348, \mathrm{p}<0.05)$ at a $12-\mathrm{hr}$ lag, indicating that near-bottom concentrations increased $12 \mathrm{hr}$ after concentrations at the upper pump increased. This pattern is consistent with migrations between these two depths. Of the total gastropods collected at the upper and bottom pumps, $66 \%$ were collected at the upper pump during the night, whereas $64 \%$ were collected at the bottom pump during the day. All results are consistent with nocturnal ascent and daytime descent migration patterns.

\section{Zoea Concentration Time Series (enumerated at the upper and bottom pumps only):}

Brachyuran crab zoea concentration time series collected by the upper pump showed similar qualitative patterns to the concentration time series collected at the bottom pump (Fig. 3.7) of increased abundance (of order 10's -100 's) during periods of warm water, and decreased abundance (of order $0-10$ 's) during periods of cool water. Thus, their concentration time series displayed low-frequency patterns opposite those of the polychaetes. Because increased concentrations of zoea were found in warm, salty water at the upper pump at the start of the time series (August 11-15), as well as in warm, lesssaline water at the end of the time series (August 23-31), a closer association with water temperature than with salinity might be indicated. However, maximal peaks in zoea concentration were observed at both the upper and bottom pumps during a period when 


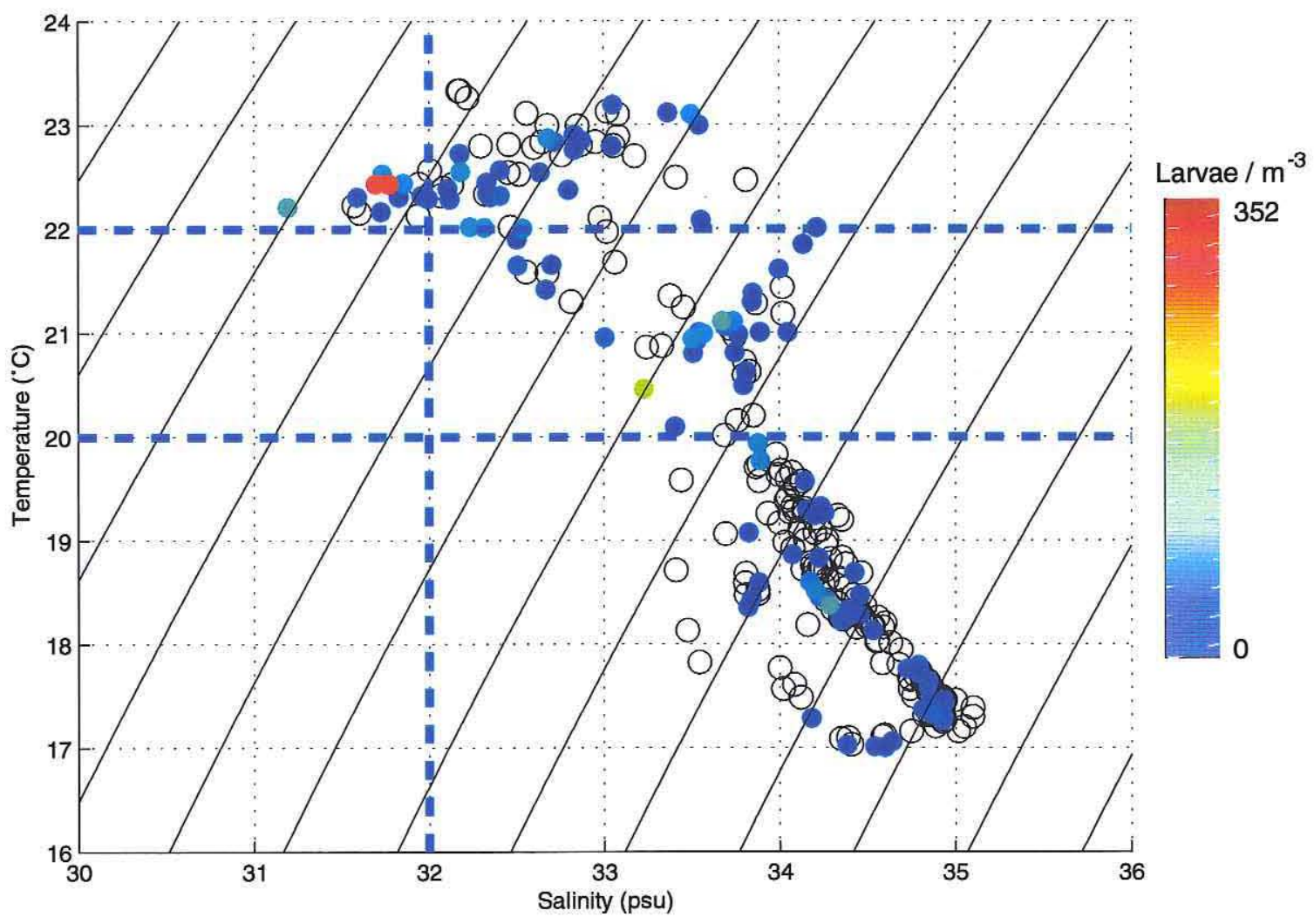

Figure 3.15 Temperature-Salinity-Plankton (T-S-P) plot for zoea larvae. Larval concentration is plotted as a function of temperature and salinity. Relative larval concentrations are shown in color (maximum in red and minimum in blue) and are scaled to the range of the data $\left(0-352 / \mathrm{m}^{\wedge} 3\right)$. Refer to Fig. 3.8 for explanation of blue dashed lines and black contours. Note slight clustering of high larval concentrations above the thermocline. Open circles represent 0 larvae $/ \mathrm{m}^{\wedge} 3$. Plot based on 320 larval samples. 
salinities were minimal. This result indicated that zoea may not be exclusively associated with warmer temperatures. Furthermore, the vertical distribution of zoea is not as distinctive as in bivalve and gastropod larvae. In the T-S-P plot for zoea (Fig. 3.15), there are no distinct clusters as compared to the other larval groups. Of the total vertical population of zoea, $46 \%$ were sampled in warm, above-thermocline water, $31 \%$ were sampled in cool, below-thermocline water, and $23 \%$ were sampled in water temperatures associated with the thermocline. This finding indicates that while the zoea were more abundant in warmer water masses, they were present throughout all types of water masses.

High-frequency diurnal variations were also observed in vertical distributions of brachyuran crab zoea (Fig. 3.10). The concentration time series of zoea at the bottom pump exhibited a statistically significant and distinct increase in autocorrelation at a 24$\mathrm{hr}$ lag, indicating a diurnal signal in the time series. Furthermore, larval concentration at the bottom pump was negatively correlated $(\mathrm{r}=-0.329, \mathrm{p}<0.05)$ with short-wave radiation at 0 lag, and positively correlated $(r=0.535, \mathrm{p}<0.01)$ at 12 -hr lags, indicating that during the day, minimal concentrations were observed near the bottom. Zoea concentrations were maximal at the upper pump during the day, and the cross-correlation $(\mathrm{r}=0.393$ at 0 lag, $\mathrm{p}<0.05)$ between zoea concentration and short-wave radiation reflected this. The cross-correlation between zoea concentrations at the upper and bottom pumps showed a positive correlation $(\mathrm{r}=0.682, \mathrm{p}<0.01)$ at a lag of $12 \mathrm{hr}$, indicating concentrations at these two depths were $12 \mathrm{hr}$ out of phase. Moreover, $75 \%$ of the total crab zoea collected at the upper pump were collected during the day, and $87 \%$ of the total 
collected at the bottom pump were collected during the night. All results offer compelling support for a reverse migration pattern of daytime ascent and nocturnal descent. Analyses of diurnal patterns were potentially confounded because the semidiurnal tide was in phase with local noon and midnight during the evaluation period for zoea (August 24-29). However, no semi-diurnal peaks were observed in the concentration time series, suggesting that circatidal rhythms were not exhibited.

\subsection{DISCUSSION AND CONCLUSIONS}

The vertically stratified, 3-wk time series of concentrations for larval polychaetes, bivalves, gastropods and brachyuran crabs accentuate the highly variable nature of planktonic larval assemblages at an inner-shelf site. Variability in the intensity, timing, and spacing of larval pulses contribute to recruitment variability for a particular location as long as the larvae are competent to metamorphose and settle into the adult habitat. Thus, obtaining a range of larval concentrations is a necessary first step in predicting how larval patchiness will influence recruitment at a given place and time. Quantifying the timing and spacing of these patches and determining which processes affect the observed patterns represents the second step.

Variability in Intensity of Larval Pulses: In this study, high concentrations of larvae were documented for inner-shelf waters. Reported larval concentrations for near-coastal, non-estuarine shelf environments are typically lower, of the order of $100^{\prime} \mathrm{s} \mathrm{m}^{-3}$, and in one case up to 5,000 larvae $\mathrm{m}^{-3}$. Using pumps to collect larvae in an "open-embayment 
sea," Banse (1986) reported $0-216$ polychaete larvae $\mathrm{m}^{-3}$. Tremblay and Sinclair (1990a) collected approximately 16 - 520 scallop larvae $\mathrm{m}^{-3}$ over Georges Bank $(40-50 \mathrm{~m}$ water column). Plankton nets towed over the New England continental shelf ( $43 \mathrm{~m}$ water column) yielded $0-4,803$ bivalve larvae $\mathrm{m}^{-3}$ (Mann 1985). The larval concentrations observed in this study are more consistent with concentrations reported (of order 1000 $10,000 \mathrm{~m}^{-3}$ ) for shallow embayments or estuaries (e.g., Nelson, 1925, 1928; Raby et al. 1994).

Differences in larval concentrations in shelf and inner-shelf waters may be due to seasonal and latitudinal differences and the different assemblages of species collected. Considering the great spatial and temporal variability observed in this study, however, it is likely that some of the published estimates and the estimates reported in Chapter 2 are low as a result of the limited sampling regimes of the studies. Depending upon the timing and depth of sampling in the present study, larval concentrations varied up to four orders of magnitude, which covers the range in concentrations reported by others. Studies sampling with increased spatial and temporal coverage using similar time-series technology for larval sampling are beginning to report similarly high abundances of invertebrate larvae in inner-shelf regions (e.g., Ma et al. 1999; Butman et al. in prep.).

Associations with Water Masses: Over relatively long time scales (of order several days, at least), larvae were associated with particular water masses (Figs. 3.4-3.7, 3.9, 3.12, 3.14 and 3.15), defined by temperature-salinity characteristics. Larval polychaetes, bivalves and gastropods were more abundant in cooler, more-saline water masses below 
the thermocline, whereas crab zoea were more abundant in warmer, less-saline water masses. In addition, high concentrations of bivalve and gastropod larvae - possibly different assemblages of species than the cold-water groups - were occasionally found in warm water masses advected to the site during strong downwelling conditions.

The existence of at least two sub-groups of bivalves, each associated with a different water mass, best explains the low-frequency variations and vertical patterns exhibited in the bivalve concentration time series (Fig. 3.5). The T-S-P plot (Fig. 3.12). The species data (Fig. 3.13) also support this two sub-group explanation. One sub-group may have tracked with cool water just below the thermocline, and the other may have tracked with warmer less-saline water. Determining the origin (cross-shelf versus alongshore) of the episodic second sub-group is problematic given that they were only observed during a single, downwelling event. Larvae may have been associated with warm surface water and advected cross-shelf during downwelling. However, the low abundances of bivalve larvae observed in warm, surface water at the start and end of the concentration time series, are inconsistent with the second sub-group tracking with warm surface water. Conversely, an alternate scenario considers the sub-group of bivalve larvae to have been associated with warm, low-salinity Chesapeake Bay plume water, advected alongshore, and mixed (or settled) downward from a more concentrated source at the surface. The presence of a plume-water population would account for the higher abundances found at all depths in warm, less-saline water and for the extremely low abundances found in warm, salty water at the start and end of the time series. These findings are inconclusive, however, because 32 psu is considered the highest salinity 
associated with the Chesapeake Bay plume (Rennie et al. 1999). Only the upper and middle pumps sampled briefly in water $<32$ psu. At the bottom pump, salinity was low (32.2 psu), but consistent with the salinity of surface waters not associated with the plume. Additional observations during downwelling conditions are required to determine the origin of the second sub-group of bivalve larvae.

Regardless of larval origin, the time series of bivalve concentration (Fig. 3.13) with identification to species, genus or family, as well as the T-S-P plot (Fig. 3.12), indicate that at least two sub-groups of bivalves were collected, each associated with a different water mass. Similarly, it would appear that at least two sub-groups of gastropods were collected (Figs. 3.6 and 3.14). These results imply that, in some cases, larval associations with water masses may be more specific at a level below major taxonomic grouping.

The sub-thermocline distribution of polychaete larvae observed in this study has also been observed by Banse $(1964,1986)$ and Thiébault et al. (1992). Banse suggested that larvae are "captured" in the water mass into which they are spawned, although this hypothesis was never tested. It is plausible that polychaete larvae were spawned into the cool bottom water over the inner shelf, and zoea were spawned in the warm, low-salinity water of the Chesapeake Bay Estuary. For the bivalves, however, species or speciesgroups that were associated with cooler water masses were representative of both shelf (e.g., Spisula, Tellina spp. and Pholadidae) and intertidal (e.g., Ensis and Tellina spp.) inhabitants (Fig. 3.13; Gosner 1979). These findings do not appear to support Banse's hypothesis because shelf and intertidal species, which are probably spawned into 
different water masses, would be expected in different water masses as larvae. An alternate explanation is that larvae of intertidal species may be released into either cool or warm water masses depending upon whether upwelling or downwelling conditions prevailed at the time of spawning. As long as the water mass stayed intact, the larval patch would have remained intact as well. Information on larval origin and preferred habitats of invertebrate species are needed to test Banse's hypothesis.

Vertical Distributions: Vertical distributions within specific water masses were groupspecific and varied over both long (several days) and short (diurnal) time scales (Figs. 3.4 $-3.7 ; 3.10)$. Low-frequency temporal variations in larval concentration resulted primarily from cross-shelf transport of water masses in which larvae were positioning themselves relative to the thermocline, and higher-frequency variations resulted primarily from diel vertical migration. Determining the biological causes of these phenomena was outside the scope of this study, although compromises among larval origin, physiological tolerances, maximizing feeding and minimizing predation are likely involved (see Chapter 1, section 1.2.3).

During periods of cold water, polychaete larvae were distributed throughout the depth interval below the thermocline (Fig. 3.4). Banse (1986) also reported no vertical stratification of polychaete larvae below the thermocline, and interpreted this result as passive larval transport of neutrally-buoyant particles. He further suggested that uniform distributions could have resulted from random spawning and similar survival rates within the water mass. Yet, polychaete larvae are not neutrally buoyant, and have sinking 
speeds in the range of $0.07-0.19 \mathrm{~cm} \mathrm{sec}^{-1}$ (Mileikovski 1973; Hannan 1984; Butman 1986). Therefore, physical processes (e.g., vertical mixing) or larval swimming behaviors must be invoked to explain this vertical distribution; otherwise polychaete larvae would exhibit skewed near-bottom distributions. Since polychaetes occurred in stratified water, larval swimming behaviors were expected. If their horizontal swimming speeds (ca. $0.05-0.52 \mathrm{~cm} \mathrm{sec}^{-1}$; Konstantinova 1966, 1969; Butman et al. 1988) are reflective of their vertical swimming speeds, polychaete larvae may be able to compensate for their settling velocities.

In laboratory test tanks, Harder (1968) observed no accumulation of polychaete larvae near a pycnocline, yet in field studies, Scrope-Howe and Jones (1986) observed intense concentrations of polychaete larvae near the pycnocline. Phenomena that might account for the discrepancies among studies include differences in the species assemblage or stages collected, seasons, latitudes, nature of the pycnocline (e.g., the steepness of the gradient), and the vertical sampling resolution.

Polychaete larvae collected in the present study exhibited a statistically significant diurnal cycle in abundance, reflective of diel vertical migration to upper layers during the night when visual predators are ineffective. Although Banse (1986) observed no sign of diel migrations in the polychaete larvae collected in Kiel Bay, nocturnal migrations have been reported for larvae of Poecilochaetus serpens (Russell, 1928) and Polydora sp. (Daro 1973).

Over a relatively long (several-day) period, high concentrations of bivalves were found in the cool water below the thermocline, but closer to the thermocline than the 
polychaetes (Figs. 3.4-3.5). Similar sub-thermocline bivalve distributions have been documented for other geographical regions. Scrope-Howe and Jones (1986) reported an increase in bivalve concentration associated with the thermocline of the western Irish Sea. Mann (1985) observed increased concentrations below the thermocline during months when the water column was stratified over the New England continental shelf. The tendency to accumulate below the thermocline has also been observed in the laboratory (Harder 1968). Hypotheses have been advanced claiming nutritional or predation-avoidance benefits to this distribution. For example, predation by benthic organisms may represent a greater pressure than the threat from planktonic predators using visual cues (Rumrill 1990). In contrast, model simulations of the vertical distribution of bivalve larvae demonstrated that similar vertical patterns of abundance relative to a pycnocline could be generated exclusively by differential swimming behavior (i.e., swimming and sinking) in response to temperature and salinity (Dekshenieks et al. 1996). For example, a concentrated sub-pycnocline distribution would result if larvae swam (upward) under more-saline conditions and stopped swimming under less-saline conditions. Similarly, the distribution could be explained primarily by feeding activities. Bivalve larvae must swim in order to feed. Thus, bivalve larvae may swim (upward) while feeding, become satiated as they approach the thermocline, and begin to sink again as they stop feeding.

Some studies have shown the opposite vertical patterns, however, where concentrations were higher above the thermocline and at the surface (e.g., Gallager et al. 1996; Tremblay and Sinclair 1990b; Raby et al. 1994; Pineda 1999). The causes of the 
discrepancy between an above-thermocline distribution and the below-thermocline distribution observed in the present study cannot be explained because species and stage information and larval sampling above the thermocline were limited in the present study. With better sampling above the thermocline and species information, it may turn out that these findings are not conflicting.

Swimming speeds of larval bivalves (ca. 0.05 to $1 \mathrm{~cm} \mathrm{sec}^{-1}$; Chia et al. 1984) are sufficient to accomplish active migration on a diel basis (e.g., Mileikovsky 1973; Forward 1976; Chia et al. 1984; Mann et al. 1991). Diel vertical migrations have been observed for bivalve species occurring in estuaries, where water depths are generally shallow and the vertical gradients of environmental variables are steep (e.g., Kunkle 1958; DeWolf 1974; Stancyck and Feller 1986). The fact that some non-estuarine bivalve larvae migrate vertically on a diel cycle has been demonstrated directly in mesocosm experiments (e.g., Kaartvedt et al. 1987; Silva and O'Dor 1988; Gallager et al. 1996; Manuel 1996) and inferred from field distributions (e.g., Quayle 1952; Petipa 1955; Verwey 1966; Scrope-Howe and Jones 1986; Tremblay and Sinclair 1990b; Raby et al. 1994). The results of the present study provide additional evidence of diel vertical migration in inner-shelf bivalve larvae. Bivalves collected at the upper and bottom pumps showed increases in autocorrelation at a $24-\mathrm{hr}$ lag, which is suggestive of diurnal forcing. Furthermore, the cross-correlation between larval concentration at the upper pump and light levels was consistent with a migration pattern of nocturnal ascent and daytime descent. However, the bivalve concentration time series from the middle pump did not exhibit major diurnal trends. It is possible that the bivalves at the upper and 
bottom pumps may be migrating independently of each other. Alternatively, variations in behavior of species, individuals, or specific ontogenetic stages may have led to asynchrony in group responses, thereby diminishing a statistically significant signal.

Gallager et al. (1996) observed vertical patterns of low bivalve abundances at intermediate depths between the upper and lower migration limits, even though the scallop larvae were clearly migrating through the intermediate depths. Although bivalves were migrating above the thermocline in that study, as opposed to below the thermocline in the present study, this observation is consistent with the relative depth-dependent variations observed in the present study. Gallager et al. (1996) interpreted the vertical abundance patterns as asynchronous migrations of individual larvae, and that concentrations of migrating larvae were low over time at intermediate depths despite the fact that larvae were migrating through those depths.

Temporal patterns (Fig. 3.6) and the T-S-P plot (Fig. 3.13) suggest that the larval gastropod grouping included at least two sub-groups, and possibly a third sub-group that was concentrated near the bottom. The majority of gastropods were found below the thermocline, but in a tighter vertical band than the bivalves. Gastropods have greater swimming capabilities (ca. $0.13-1.5 \mathrm{~cm} \mathrm{sec}^{-1}$; Konstantinova 1966; Richter 1973) than bivalves or polychaetes, therefore they may be expected to have greater control over their vertical position in the water column.

A tight distribution of concentrated gastropod larvae close to the thermocline is consistent with laboratory observations (Harder 1968), but few field studies have examined the vertical distribution of gastropod larvae. Scrope-Howe and Jones (1986) 
observed higher concentrations of gastropod larvae above the thermocline. This observation is in contrast to the major sub-thermocline distributions observed in the present study, but may be consistent with the second sub-group of gastropods that tracked with warm, less-saline water associated with the August 24-26 downwelling event. An above-thermocline distribution of larvae that is vertically narrow will vertically expand and be reflected as peaks in concentration that occur at all depths as the downwelled thermocline passes the site. With limited species and stage information, however, it is difficult to attribute these discrepancies to specific physical or behavioral processes. Furthermore, it is possible that larval heteropods (holoplanktonic prosobranch gastropods) were collected and included in the gastropod grouping. In fact, dense swarms of adult heteropods were observed near the thermocline at the study site (E.D. Garland, pers. observation).

Diel vertical migration of gastropod larvae was observed in this study, and has been documented in the laboratory (e.g., Richter 1973; Barile et al. 1994) and inferred from distributions observed in the field (e.g., Petipa 1955; Daro 1973; Richter 1973). The present study indicated a migration pattern of nocturnal ascent of gastropod larvae. Richter (1973) reported nocturnal ascent patterns for holoplanktonic larval heteropods (a sub-group of prosobranch gastropods), but found a reverse pattern of daytime ascent in one species (Bittium) of meroplanktonic prosobranchs. Barile et al. (1994) observed a nocturnal ascent migration pattern, however, in another species of meroplanktonic prosobranch (Strombus gigas, the queen conch). Although Strombus larvae are unlikely to be found in samples from this study site, the finding indicates that patterns of vertical 
migration (e.g., nocturnal or reverse) can not be generalized according to whether prosobranch larvae are holoplanktonic or meroplanktonic.

Zoea concentration time series showed no appreciable depth-dependent variability over relatively long periods of time during both well-mixed and stratified conditions (Fig. 3.7). Although crab zoea are strong swimmers (ca. $0.4-2.2 \mathrm{~cm} \mathrm{sec}^{-1}$; Forward and Cronin 1980; Sulkin et al. 1980), it appears that they did not exhibit depth preferences over a several-day period. On shorter time scales, however, diurnal variations were observed. In contrast to the nocturnal migration patterns reported for brachyuran crab zoea (Russell 1928; Petipa 1955; Robertson and Howard 1978; Forward et al 1984; Cronin and Forward 1986), a reverse migration pattern of daytime ascent was observed in the present study. This result was interpreted to indicate either that the types of crab zoea collected in this study did not face pressure from visual predators, or that the crab zoea feed most effectively using visual cues.

Ecological Consequences: High concentrations of larvae were observed at an innershelf site, but concentrations were extremely variable over time. Over long time scales (of at least several days), larvae were associated with particular water masses, defined by temperature-salinity characteristics; and within a particular water mass, group-specific vertical patterns were observed over both long and short (diurnal) time scales. Lowfrequency temporal variations in larval concentration resulted primarily from cross-shelf transport of water masses in which larvae were differentially distributed relative to the 
thermocline, and higher-frequency variations could be attributed to diel vertical migrations.

In addition to nutritional benefits and escape from predation, another ecological consequence of diel vertical migration is differential advection in vertically sheared flows (e.g., Mileikovsky 1973; Hill 1991a, 1991b, 1994; Thiébault et al. 1992). The diel vertical migrations observed in this study, however, are not likely to have caused appreciable differential cross-shelf transport because the migrations appeared to be confined to depths below the thermocline, where currents were generally unidirectional. In general, under upwelling conditions, sub-thermocline larval groups were moved shoreward whether or not they migrated vertically (Fig. 3.3). Instead, vertical migrations could determine the time intervals during which larvae occur in near-bottom water and have the opportunity to contact and settle onto the bottom. Thus, the most advantageous consequences of diel vertical migration at the study site include escape from predation, enhanced feeding at depths closer to the thermocline, and an opportunity for larvae to contact the bottom.

Lower-frequency patterns, such as larval associations with different water masses and their vertical positioning within those water masses, may also lead to differential feeding, growth and mortality. Furthermore, larvae are moved differentially by the physical processes that move water masses. For example, low-frequency (order several days) variations in larval concentrations were associated with low-frequency thermal variations, which resulted primarily from wind-driven upwelling and downwelling advective events at the study site. 
Although the cross-correlations between the biological time series and time series of temperature, alongshore wind velocity, or other indicators of upwelling and downwelling, were not statistically significant, the associations were strong (Figs. 3.4 3.7). Larvae and heat were moved in similar ways. Lack of statistical significance was partially due to the limited number of independent values in the low-frequency response of temperature, salinity and density data series. More realizations of upwelling and downwelling conditions may increase statistical significance of the associations. Yet, sampling time is ultimately limited by the typical length of a larva's life, which is on the order of several weeks to over a month. Interpretation of longer concentration time series would be confounded by the expected increase in the number of species and ontogenetic stages collected. In the case of larval bivalves and gastropods, the results suggest that, in addition to having very few independent upwelling and downwelling observations, there were at least two sub-groups sampled, each displaying a different association with temperature and salinity. Reduced linear correlations are likely when considering two or more groups with distinctly different water mass associations. In this case, increased taxonomic resolution may increase statistical significance.

Nevertheless, the diversity of low-frequency temporal responses observed in the larval concentration time series appeared to result from wind-driven upwelling and downwelling operating on both a thermally stratified water column and on larval groups which are also thermally and vertically stratified. Thus, in this study, larvae were passive to the degree that they were horizontally advected with the water masses they were 
associated with, but active to the degree where they could alter their vertical position within a water mass.

The observed associations of larvae with specific temperature fields and depths may represent advantageous transport strategies for larvae in an environment with persistent stratification and intermittent upwelling during the months when many larval groups are dispersing. Unique associations with different water masses and different vertical distributions within those water masses ensure that some degree of habitatpartitioning will occur. Polychaete larvae that live in soft sediments as adults are able to cover a wide span of the inner-shelf, maximize their onshore transport (during times when upwelling prevails), minimize their alongshore transport, and move over their preferred soft-sediment adult habitats, if they remain associated with cool water masses. Gastropod and bivalve larvae occur near and below the thermocline, thereby minimizing cross-shelf transport and possibly maximizing feeding. They are periodically delivered to the bottom during downwelling events without having to traverse steep thermal gradients, or through diel vertical migrations. Warm-water groups (zoea and some sub-groups of bivalve and gastropod larvae) are delivered to the bottom in a similar way during downwelling events without having to cross the thermocline. Furthermore, only the bivalves, gastropods and zoea larvae located inshore of approximately $7-10 \mathrm{~km}$ will be deposited directly on the bottom at the point where the downwelled thermocline intersects the bed. In deeper waters, the downwelled thermocline may never intersect the bottom. Thus, larvae would arrive at the bottom only during deep mixing events that generally occur later in the season, or through other behavioral processes (e.g., vertical 
migration). The muddy bottom of deeper waters is not a preferred adult habitat, however, for the majority of the species within these groups (Gosner 1979). Information on species and stages, as well as information on species-specific adult habitats, is needed to make the connection between larval delivery and preferred adult habitats.

This work sheds light on the studies of Farrell et al. (1991) and Roughgarden et al. (1991) which focused on settlement patterns of barnacle cyprids that recruit to intertidal benthic habitats during periods of relaxation from upwelling. The results presented in the present study contribute information on the associations of planktonic larval polychaetes, bivalves, gastropods and brachyuran crabs with different water masses and depths, and the mechanisms by which the larvae make contact with potential settling sites. The bivalve, gastropod and crab larvae make contact with subtidal inner-shelf habitats during strong downwelling events, or through diel vertical migration. The polychaete larvae make contact with subtidal inner-shelf habitats during either upwelling or downwelling events, or through diel vertical migration. Upwelling events move the polychaete larvae closer to the coast, allowing them to colonize intertidal and subtidal habitats. Downwelling events move polychaete larvae away from the coast and allow them to colonize more offshore subtidal habitats. Moreover, information on vertical distributions within particular water masses that was identified in this study can be used to model the effects of other advective processes on the transport of these larvae. Other processes that move thermal fields around (e.g., tides, internal tidal bores, and internal waves) would be expected to move vertically and thermally stratified larvae around as well. 
A combination of physical processes (wind-driven upwelling and downwelling) and larval behavior (larvae positioning themselves vertically relative to the thermocline and undergoing diel vertical migrations) accounts for the majority of vertical and temporal variability in larval concentrations observed at this site, and would appear to transport these organisms to favorable adult habitats. The question remains regarding the generality of these results. Because the majority of larvae in all groups were shown to be more strongly associated with temperature than with salinity, the observed low-frequency temporal variability was likely due to cross-shelf (versus alongshore) movements of larvae (Austin 1999; Lentz et al 1999; refer to section 3.3). This finding suggests that the same physical mechanism would probably produce similar variations at similar depths along the coast, but that the observed effects of the forcing mechanism may differ inshore and offshore of the study site.

Presently, there is no objective way to couple directly the observed variability in timing, spacing and intensity of larval pulses to recruitment into benthic populations at the study site. This is partly due to a lack of appropriate sampling technology for evaluation of recruitment into soft-substrate habitats at these time and space scales (but see Whitlatch and Osman 1998; Butman et al. 1999; Ma et al. 1999). It is also due to the fact that no methods are currently available for definitive determination of "metamorphic competency" - a developmental state signaling the likely onset of metamorphosis once a larva has settled on the seafloor — for most larval groups (except some barnacles, crabs and echinoderms) in preserved samples. Instead, these results indicate the times and spaces where and when the coupling can occur, and lead to certain predictions regarding 
the places and times larval settlement should be greatest. For example, settlement of polychaetes should be more consistent and occur over longer periods of time and a wider span of the inner-shelf. In contrast, settlement of bivalves, gastropods and zoea is expected to be more episodic, occur during strong downwelling events, and be concentrated in shallower depths of the inner shelf where the downwelled thermocline intersects the bottom. Furthermore, conditions at the bed must be optimal over longer periods of time in order for settlement to be successful for larval groups with shorter time scales of variability (bivalves, gastropods and zoea), whereas conditions at the bed can be optimal over a wider range of times (from short to long) for larval groups with longer time scales of variability (polychaetes).

Quantification of the actual coupling process, and the relative contributions from diurnal and lower-frequency or episodic larval inputs, await the availability of appropriate benthic sampling technologies and methods for the identification of species and ontogenetic stages for these specific larval groups. The division between high- and low-frequency processes affecting near-bottom larval availability is artificial and lacks ecological significance. Determining how processes operating at these two time scales and other scales are coupled and influence recruitment variability represents a challenging extension of this work for the future. 


\subsection{ACKNOWLEGEMENTS}

It is a pleasure to acknowledge the assistance of many people involved in the collection of data used in this study. I thank Dave Simoneau, Willie Ostrom, John Bouthillette, Larry Costello, Craig Marquette, Jay Sisson, Vicke Starczak and the captain and crews of the $R / V$ Endeavor and $R / V$ Cape Hatteras for assistance with mooring deployment and recovery. Ken Doherty, Ken Fairhurst, Steve Longworth and Jay Sisson provided engineering advice and assistance with the pumps. Jay Sisson, Carrie Kapple, Chris Harley, Walt Waldorf, Woody Sutherland, Tom Chisholm, Wayne Spencer, Britt Raubenheimer and Sandy Williams assisted with the diving operations. Bill Birkemeirer, the staff at the Field Research Facility in Duck, NC, and scientists participating in the ONR Duck94 Field Study provided a productive and enjoyable collaboration.

Next, the time-series larval samples were turned into time-series data over the course of several years. Under the supervision of Nancy Mountford and Suzanne Arcuri, Cove Corp., Lusby, MD, sorted the larval samples from the upper and bottom pumps. Preprocessing of these samples was done by Vicke Starczak, Nan Trobridge, Jeannie Sisson, Jay Sisson, Maureen Murray and Annette Frese. Rich Lutz and Alan Pooley (Rutgers) provided support with the Scanning Electron Microscope and provided an indispensable reference collection of photomicrographs of bivalve hinge structure. Conversations with Laura Brink aided with bivalve species identifications.

Finally, the larval concentration time-series data were interpreted relative to oceanographic conditions at the site. I thank Steve Lentz, in particular, for his patience in describing the subtle and unpublished aspects of the physical environment necessary for the interpretation of the larval concentration time series.

CoOP PI's (Cheryl Ann Butman, Steve Lentz, Bob Guza, John Largier, Don Wright, Ole Madsen, Alan Shanks and John Brubaker), support scientists (Walt Waldorf, Kimball Millikan, Cheryl Greengrove, S. Kim, Vicke Starczak, Jay Sisson, Carl Friedrichs, Guanhong Lee and Tom Rippetoe) and students (Jay Austin, Sarah Rennie, Laura Brink Tom Chisholm, Falk Fedderson and Kevin Johnson) aided with all aspects of the project.

My deepest appreciation is extended for all contributions.

This research was supported by grants from NSF's Coastal Ocean Processes (CoOP) Program (OCE91-23514 and OCE92-21615 to Cheryl Ann Butman and OCE96-33025 to Steven J. Lentz and Cheryl Ann Butman). Aspects of the research involving species identification of bivalve larvae were funded by the NOAA National Sea Grant Program Office, Department of Commerce (Grant \# NA46RG0470, Woods Hole Oceanographic Institution Sea Grant Project No. RB-132 and RB-139 to Cheryl Ann Butman and Elizabeth D. Garland). 


\subsection{LITERATURE CITED}

Alessi, CS, Lentz S, Austin J (1996). Coastal Ocean Processes Inner Shelf Study: Coastal and moored physical oceanographic instruments. Woods Hole Oceanogr. Inst. Tech. Rpt. WHOI-96-06, 142 pp.

Austin JA (1998). Wind-driven circulation on a shallow, stratified shelf. Doctoral Dissertation. Massachusetts Institute of Technology / Woods Hole Oceanographic Institution, Woods Hole, MA. $246 \mathrm{pp}$.

Austin JA (1999). The role of the alongshore wind stress in the heat budget of the North Carolina inner shelf. J. Geophys. Res. 104: 18187-18203.

Austin JA, Lentz SJ (1999). The relationship between synoptic weather systems and meteorological forcing on the North Carolina inner shelf. J. Geophys. Res. 104: 1815918185.

Banse K (1964). On the vertical distribution of zooplankton in the sea. Prog. Oceanogr. 2: $53-125$.

Banse K (1986). Vertical distribution and horizontal transport of planktonic larvae of echinoderms and benthic polychaetes in an open coastal sea. Bull. Mar. Sci. 39: 162175.

Barber RT, Smith RL (1981). Coastal upwelling ecosystems. In: Longhurst AR (ed.), Analysis of Marine Ecosystems. Academic Press, NY, pp. 31-68.

Barile PJ, Stoner AW, Young CM (1994). Phototaxis of the queen conch (Strombus gigas Linne) veliger larvae. J. Exp. mar. Biol. Ecol. 183: 147-162.

Bary BM (1959). Species of zooplankton as a means of identifying different surface waters and demonstrating their movements and mixing. Pacific Sci. 13(1): 14-54

Bary BM (1963). Temperature, salinity and plankton in the eastern North Atlantic and coastal waters off Britain, 1957. II. The relationships between species and water bodies. J. Fish. Res. Bd. Canada 20: 1031-1065.

Bary BM (1964). Temperature, salinity and plankton in the eastern North Atlantic and coastal waters off Britain, 1957. IV. The species' relationship to the water body; its role in distribution and in selecting and using indicator species. J. Fish. Res. Bd. Canada 21: 183-202.

Birkemeier WA, Miller HC, Wilhelm D, DeWall AE, Gorbics CS (1985). User's guide to the Coastal Engineering Research Center's (CERC's) Field Research Facility. 
Instruction Report CERC-85-1, May 1985. Coastal Engineering Research Center, US Army Engineer Waterways Experiment Station, Vicksburg, Mississippi, USA

Boicourt WC (1973). The circulation of water on the continental shelf from Chesapeake Bay to Cape Hatteras. Ph.D. Thesis, The Johns Hopkins University, Baltimore, MD.

Boicourt WC (1988). Recruitment dependence on planktonic transport in coastal waters. In: Rothschild BJ (ed.), Toward a Theory on Biological-Physical Interactions in the World Ocean. Kluwer Academic Publishers, Boston, MA, pp. 183-202.

Boicourt WC, Chao S-Y, Ducklow HW, Gilbert PM, Malone TC, Roman MR, Sanford LP, Fuhrman JA, Garside C, Garvine RW (1987). Physics and microbial ecology of a buoyant plume on the continental shelf. EOS, Trans. Amer. Geophys. Union. 68: 666668.

Bowden KF (1965). Horizontal mixing in the sea due to a shearing current. J. Fluid Mech. 21: 83-95.

Bradshaw J (1959). Ecology of living planktonic Foraminifera in the North and Equatorial Pacific Ocean. Cont. Cushman Foundation for Foram. Res. (Pt 2). 10: 25-64.

Butman CA (1986). Larval settlement of soft-sediment invertebrates: Some predictions based on analysis of near-bottom velocity profiles. In: Nihoul JCJ (ed.). Marine Interfaces Ecohydrodynamics. Elsevier Oceanography Series, Vol. 42, New York, pp 487-514.

Butman CA (1987). Larval settlement of soft-sediment invertebrates: The spatial scales of pattern explained by active habitat selection and the emerging rôle of hydrodynamical processes. Oceanogr. Mar. Biol. Ann. Rev. 25: 113-165.

Butman CA (1994). CoOP, Coastal Ocean Processes Study: Interdisciplinary approach, new technology to determine biological, physical, geological processes affecting larval transport on the inner shelf. Sea Technol. 35: 44-49.

Butman CA, Starczak VR, Garland ED, Lentz SJ (In prep.). Evidence of wind-driven larval transport across the inner shelf. II. Spatial patterns. (for Limnol. Oceanogr.).

Butman CA, Grassle JP, Buskey EJ (1988). Horizontal swimming and gravitational sinking of Capitella sp. I (Annelida: Polychaetea) larvae: Implications for settlement. Ophelia 29: 43-57.

Butman CA, Starczak V, Grassle JP, Snelgrove PV (1999). Sediment selection and larval availability in a coastal embayment. Am. Soc. Limnol. Oceanogr., Meeting Feb. 15, 1999, Santa Fe, NM (Abstract). 
Caffey HM (1985). Spatial and temporal variation in settlement and recruitment of intertidal barnacles. Ecol. Monogr. 55: 313-332.

Chatfield C (1989). The Analysis of Time Series: An Introduction, 4th ed. Chapman and Hall, NY.

Connell JH (1985). The consequences of variation in initial settlement vs. postsettlement mortality in rocky intertidal communities. J. Exp. Mar. Biol. Ecol. 93: 11-45.

Connolly SR, Roughgarden J (1999). Increased recruitment of northwest Pacific barnacles during the 1997 El Niño. Limnol Oceanogr. 44: 466-469.

Daro MH, Polk P (1973). The autecology of Polydora ciliata along the Belgian coast. Neth. J. Sea Res. 6: 130-140.

Dekshenieks MM, Hofmann EE, Klink JM, Powell EN (1996). Modeling the vertical distribution of oyster larvae in respect to environmental conditions. Mar. Ecol. Progr. Ser. 136: 97-110.

DeWolf (1974). On the retention of marine larvae in estuaries. Thalassia Jugosl. 10: 415-424.

Diggle PJ (1990). Time Series: A Biostatistical Introduction. Clarendon Press, Oxford.

Dixon PA, Milicich MJ, Sugihara G (1999). Episodic fluctuations in larval supply.

Science. 283: 1528-1530.

Doherty KW, Butman CA (1990). A time- or event-triggered, automated, serial, plankton-pump sampler. In: Frye D, Stone E, Martin A (eds.), Advanced Engineering Laboratory Projects Summaries - 1989, WHOI Tech. Rept. 90-20, pp. 15-23.

Ekman VW (1905). On the influence of the earth's rotation on ocean-currents. Arkiv. för matematik, astronomi o. fysik. 2(11): 1-53.

Emery WJ, Thompson RE (1997). Data Analysis Methods in Physical Oceanography. Pergamon Press, New York.

Farrell TM, Bracher D, Roughgarden J (1991). Cross-shelf transport causes recruitment to intertidal populations in central California. Limnol. Oceanogr. 36: 279-288.

Fedderson F, Guza RT, Elgar S, Herbers THC (1998). Alongshore momentum balances in the nearshore. J. Geophys. Res. 103: 15667-15676. 
Forward RB Jr., Cronin TW (1980). Tidal rhythms in activity and phototaxis by an estuarine crab larva. Biol. Bull. 158: 295-303,

Forward RB Jr., Cronin TW, Stearns DE (1984). Control of diel vertical migration: Photoresponses of a larval crustacean. Limnol. Oceanogr. 29: 146-154.

Gaines SD, Brown S, Roughgarden J (1985). Spatial variation in larval concentrations as a cause of spatial variation in settlement for the barnacle, Balanus glandula. Oecologia 67: $267-272$.

Gallager SM, Mann R (1986). Growth and survival of larvae of Mercenaria mercenaria (L.) and Crassostrea virginica (Gmelin) relative to broodstock conditioning and lipid content of eggs. Aquacult. 56: 105-121.

Gallager SM, Manuel JL, Manning DA, O'Dor R (1996b). Ontogenetic changes in the vertical distribution of giant scallop larvae, Placopecten magellanicus, in 9-m deep mesocosms as a function of light, food, and temperature stratification. Mar. Biol. 124: $679-692$.

Gosner KL (1979). Guide to Identification of Marine and Estuarine Invertebrates. Cape Hatteras to Bay of Fundy. Wiley-Interscience, NY.

Hannan CA (1984). Initial settlement of marine invertebrate larvae: The role of passive sinking in a near-bottom turbulent flow environment. PhD Dissertation, Massachusetts Institute of Technology / Woods Hole Oceanographic Institution Joint Program in Oceanography.

Harder W (1968). Reactions of plankton organisms to water stratification. Limnol. Oceanogr. 13(1): 156-168.

Haury LR, McGowan JA, Wiebe PH (1978). Patterns and processes in the time-space scales of plankton distributions. In: Steele JH (ed.). Spatial pattern in plankton communities. Plenum Press, NY, p. 277-327

Haury LR (1982). Mesoscale processes: some biological and physical connections. EOS, Trans. Am. Geophys. Union 63: 267-275.

Kaartvedt S, Aksnes DL, Egge JK (1987). Effect of light on the vertical distribution of Pecten maximus larvae. Mar. Ecol. Progr. Ser. 40: 195-197.

Kim BO (1996). Modeling storm-induced sediment transport on the inner shelf: Effects of bed microstratigraphy. Doctoral Dissertation. School of Marine Science, College of William and Mary, Gloucester Point, VA, 178 pp. 
Kim SC, Wright LD, BO Kim (1997). The combined effects of synoptic and local-scale meteorological events on bed stress and sediment transport on the inner shelf of the Middle Atlantic Bight. Cont. Shelf Res. 17: 407-433.

Konstantinova MI (1966). Characteristics of movement of pelagic larvae of marine invertebrates. Dokl. Akad. Nauk. SSSR. 170: 726-729.

Konstantinova MI (1969). Movement of polychaete larvae. Dokl. Akad. Nauk. SSSR. 188: 942-945.

Kullenberg GEB (1972). Apparent horizontal diffusion in stratified vertical shear flow. Tellus. 24: 17-28.

Kullenberg GEB (1978). Vertical processes and the vertical-horizontal coupling. In: Steele JH (ed.), Spatial Pattern in Plankton Communities. Plenum Press, NY, pp. 43-71.

Kunkle DE (1957). The vertical distribution of oyster larvae in Delaware Bay. Proc. Nat. Shellfish Assoc. 48: 90-91.

Lentz SJ, Carr M, Herbers THC (in prep). Barotropic tides on the North Carolina shelf. (for J. Geophys. Res.)

Lentz SJ, Guza RT, Elgar S, Feddersen F, Herbers THC (1999). Momentum balances on the North Carolina inner shelf. J. Geophys. Res. 104: 18205-18226.

Levin LA (1986). The influence of tides on larval availability in shallow waters overlying a mudflat. Bull. Mar. Sci. 39: 224-233.

Longhurst AR, Reith AD, Bower RE, Seibert DLR (1966). A new system for the collection of multiple serial plankton samples. Deep Sea Res. 13(2): 213-222.

Lutz R, Goodsell J, Castagna M, Chapman S, Newell C, Hidu H, Mann R, Jablonski D, Kennedy V, Siddall S, Goldberg R, Beattie H, Falmagne C, Chestnut A, Partridge A (1982). Preliminary observations on the usefulness of hinge structures for identification of bivalve larvae. J. Shell. Res. 2: 65-70.

Lutz RA, Jablonski D (1978a). Classification of bivalve larvae and early postlarvae using scanning electron microscopy. Am. Zool. 18: 647.

Ma H, Grassle JP, Butman CA (1999). Mesoscale spatial distribution of surf clam larvae at LEO-15 on the New Jersey continental shelf. Amer. Soc. Limnol. Oceanogr., Meeting Feb. 1-5, 1999, Santa Fe, NM (Abstract). 
Mann R (1985). Seasonal changes in the depth-distribution of bivalve larvae on the southern New England Shelf. J. Shellfish Res. 5: 57-64.

Mann R (1986). Sampling of bivalve larvae. In: Jamieson GS, Bourne N (eds.), North Pacific Workshop on Stock Assessment and Management of Invertebrates, Can. Spec. Publ. Fish. Aquat. Sci. 92: 107-116.

Manuel JL (1996). Population and temporal variations in the vertical migrations of scallop (Placopecten magellanicus) veligers. Ph.D. thesis, Dalhousie University, Halifax, Nova Scotia, Canada.

Manuel JL, Gallager SM, Pearce CM, Manning DA, O'Dor RK (1996). Veligers from different populations of sea scallop Placopecten magellanicus have different vertical migration patterns. Mar. Ecol. Prog. Ser. 142: 147-163.

McEwen GF, Johnson MW, Folsom TR (1954). A statistical analysis of the performance of the Folsom Plankton Sample Splitter, based on test observations. Arch. Meterol. Geophys. Bioklim, Ser A. 7: 502-527.

Michel HB, Foyo M (1976). Caribbean Zooplankton. Part I-Siphonophora, Heteropoda, Copepoda, Euphausiacea, Chaetognatha and Salpidae. Office of Naval Research Publication, Department of the Navy. U.S. Government Printing Office, Washington, DC, pp. 1-549.

Mileikovsky SA (1973). Speed of active movement of pelagic larvae of marine bottom invertebrates and their ability to regulate their vertical position. Mar. Biol. 23: 11-17.

Miller BA, Emlet RB (1997). Influence of nearshore hydrodynamics on larval availability and settlement of sea urchins Strongylocentrotus franciscanus and $S$. purpuratus in the Oregon upwelling zone. Mar. Ecol. Progr. Ser. 148: 83-94.

Morgan SG (1995). The Timing of Larval Release. In: McEdward LR (ed.), Ecology of Marine Invertebrate Larvae. CRC Press, Inc., Boca Raton, FL, pp. 157-191.

Okubo A (1967). The effect of shear in an oscillatory current on horizontal diffusion from an instantaneous source. Int. J. Oceanol. Limnol. 1: 194-204.

Okubo A (1968). Some remarks on the importance of the "shear effect" on horizontal diffusion. J. Oceanogr. Soc. Japan. 24: 60-69.

Omori M, Ikeda J (1984). Methods in Marine Zooplankton Ecology. John Wiley and Sons, NY, pp. 79-104. 
Petipa TS (1955). Observations on zooplankton behavior during the solar eclipse. Dokl. Akad. Nauk. SSSR 104: 323-325.

Pineda J (1991). Predictable upwelling and the shoreward transport of planktonic larvae by internal tidal bores. Science 253: 548-551.

Pineda J (1994a). Internal tidal bores in the nearshore: Warm-water fronts, seaward gravity currents and the onshore transport of neustonic larvae. J. Mar. Res. 52: 427-458.

Pineda J (1994b). Spatial and temporal patterns in barnacle settlement rate along a southern California rocky shore. Mar. Ecol. Progr. Ser. 107: 125-138.

Pineda J (1999). Circulation and larval distribution in internal tidal bore warm fronts. Limnol. Oceanogr. 44:1400-1414.

Price CA, Reardon EM, Guillard RRL (1978). Collection of dinoflagellates and other marine microalgae by centrifugation in density gradients of a modified silica sol. Limnol. Oceanogr. 23: 548-553.

Quayle DB (1952). Structure and biology of the larva and spat of Venerupis pullastra (Montagu). Trans. R. Soc. Edinb. 62: 255-297.

Raby D, Lagadeuc Y, Dodson JJ, Mingelbier M (1994). Relationship between feeding and vertical distribution of bivalve larvae in stratified and mixed waters. Mar. Ecol. Progr. Ser. 103: 275-284.

Rennie S (1998). Wind interaction with buoyant plumes on the inner continental shelf. Ph.D. Dissertation, School of Marine Science, The College of William and Mary, Gloucester Point, VA. 178 pp.

Rennie S, Largier JL, Lentz SJ (1999). Observations of pulsed buoyancy current downstream of Chesapeake Bay. J. Geophys. Res. 104: 18227-18240.

Richards FA, ed. (1981). Coastal Upwelling. Coastal and Estuarine Sciences 1, American Geophysical Union, Washington, DC.

Richter G (1973). Field and laboratory observations of the diurnal vertical migration of marine gastropod larvae. Neth. J. Sea. Res. 7: 126-134.

Robertson AE, Howard RK (1978). Diel trophic interactions between vertically migrating zooplankton and their fish predators in an eelgrass community. Mar. Biol. 48: 207-213. 
Roughgarden J, Gaines S, Possingham H (1988). Recruitment dynamics in complex life cycles. Science 241: 1460-1466.

Roughgarden J, Pennington JT, Stoner D, Alexander S, Miller K (1991). Collisions of upwelling fronts with the intertidal zone: The cause of recruitment pulses in barnacle populations of central California. Acta Oecologia 12: 35-51.

Rumrill SS (1990). Natural mortality of marine invertebrate larvae. Ophelia. 32: 163198.

Russell FS (1927). The vertical distribution of plankton in the sea. Biol. Rev. 2: 213262.

Sameoto DD (1984). Vertical distribution of zooplankton biomass and species in northeastern Baffin Bay related to temperature and salinity. Polar Biol. 2: 313-224.

Scarola JF and Novotny AJ (1968). Folsom Plankton Splitter modified for enumeration of Entomostraca. Limnol. Oceanogr. 13: 195-196.

Schwinghamer P (1981). Extraction of living meiofauna from marine sediments by centrifugation in silica sol-sorbitol mixture. Can. J. Fish. Aquat. Sci. 38: 476-478.

Scrope-Howe S, Jones DA (1986). The vertical distribution of zooplankton in the western Irish Sea. Est. Coast. Shelf Sci. 22: 785-802.

Shanks AL (1995). Mechanisms of cross-shelf dispersal of larval invertebrates and fish. In: McEdward LR (ed.), Ecology of Marine Invertebrate Larvae. CRC Press, Inc, Boca Raton, FL, pp. 323-367.

Shay LK, Lentz SJ, Graber HC, Haus BK (1998). Current structure variations detected by high-frequency radar and vector-measuring current meters. J. Atmos. Oceanic Technol. 15: 237-256.

Silva MA, O'Dor RK (1988). Active depth regulation by the sea scallop larvae of Placopecten magellanicus? Bull. Can. Soc. Zool. 19: 36. (Abstract).

Smith RL (1968). Upwelling. Mar. Biol. Annu. Rev. 6: 11-46.

Stancych SE, Feller RJ (1986). Transport of non-decapod invertebrate larvae in estuaries: An overview. Bull. Mar. Sci. 39: 257-268.

Starink M, Bär-Gilissen MJ, Bak RPM, Cappenberg TE (1994). Quantitative centrifugation to extract benthic protozoa from freshwater sediments. Appl. Environ. Microbiol. 60: 167-173. 
Sulkin SD, Van Heukelem W, Kelly P, Van Heukelem W (1980). The behavioral basis of larval recruitment in the crab Callinectes sapidus Rathbun: A laboratory investigation of ontogenetic changes in geotaxis and barokinesis. Biol. Bull. 159: 402-417.

Thiébault E, Dauvin J-C, Lagadeuc Y (1992). Transport of Owenia fusiformis larvae (Annelida: Polychaeta) in the Bay of Seine. I. Vertical distribution in relation to water column stratification and ontogenic vertical migration. Mar. Ecol. Prog. Ser. 80: 29-39.

Tremblay MJ, Meade LD, Hurley GV (1987). Identification of planktonic sea scallop larvae (Placopecten magellanicus) (Gmelin). Can. J. Fish. Aquat. Sci. 44: 1361-1366.

Tremblay MJ, Sinclair MM (1988). The vertical and horizontal distribution of sea scallop (Placopecten magellanicus) larvae in the Bay of Fundy in 1984 and 1985. J. Northwest J. Atl. Fish. Sci. 8: 43-54.

Tremblay MJ, Sinclair M (1990a). Diel vertical migration of sea scallop larvae Placopecten magellanicus in a shallow embayment. Mar. Ecol. Prog. Ser. 67: 19-25.

Tremblay MJ, Sinclair M (1990b). Sea scallop larvae Placopecten magellanicus on Georges Bank: vertical distribution in relation to water column stratification and food. Mar. Ecol. Prog. Ser. 61: 1-15.

Turner RD, Boyle PJ (1975). Studies of bivalve larvae using the scanning electron microscope and critical point drying. Am. Malac. Union, Inc. Bull. 40:59-65.

Turner JT, Dagg MJ (1983). Vertical distribution of continental shelf zooplankton in stratified and isothermal waters. Biol. Oceanogr. 3: 1-40.

Verwey J (1966). The role of some external factors in the vertical migration of marine animals. Neth. J. Sea Res. 3:245-266.

Waldorf BW, Largier JL, Rennie S, Austin J, Greengrove S (1995). Coastal Ocean Processes (CoOP) pilot project data report: R/V Cape Hatteras shipboard measurements; underway CTD and ADCP data, August 1994. Scripps Inst. Oc. Ref. Ser. No. 95-29

Whitlatch RB, Osman RW (1998). A new devise for studying benthic invertebrate recruitment. Limnol. Oceanogr. 43: 516-5223.

Wiebe PH (1970). Small-scale spatial distribution in oceanic zooplankton. Limnol. Oceanogr. 15: 205-217. 
Wing SR, Largier JL, Botsford LW, Quinn JF (1995). Settlement and transport of benthic invertebrates in an intermittent upwelling region. Limnol. Oceanogr. 40: 316329 .

Yoshioka PM (1982). Role of planktonic and benthic factors in population dynamics of the bryozoan Membranipora membranacea. Ecology. 63: 457-468.

Young CM (1995). Behavior and locomotion during the dispersal phase of larval life. In: McEdward LR (ed.), Ecology of Marine Invertebrate Larvae. CRC Press, Boca Raton, FL, pp. 249-277.

Young CM, Chia F-S (1987). Abundance and distribution of pelagic larvae as influenced by predation, behavior, and hydrographic factors. In: Giese AC, Pearse JS, Pearse VB (eds.), Reproduction of Marine Invertebrates. Blackwell Scientific Publications, Palo Alto and The Boxwood Press, Pacific Grove, CA, pp. 385-463. 


\section{CHAPTER 4}

General Conclusions 


\subsection{INTRODUCTION}

This thesis research quantifies temporal and spatial characteristics of planktonic distributions of larval bivalves, gastropods, polychaetes and brachyuran crabs, and evaluates how these distributions and inner-shelf physical processes, such as wind-driven upwelling and downwelling, influence the transport of these organisms to potential adult habitats. First, temporal variability in the intensity of larval concentrations was quantified based on the direct collection of time-series larval samples. Second, larval associations with different water masses, and their vertical distributions within these water masses was evaluated using vertically stratified larval samples and hydrographic measurements. Biological and physical processes underlying the observed vertical distributions were identified.

This chapter summarizes the findings of this research (section 4.2), compares the results from the two field studies (section 4.3), and provides recommendations for future research (section 4.4).

\subsection{CONCLUSIONS OF THE 1993 AND 1994 FIELD STUDIES}

Time-series larval samples collected in July 1993 (Chapter 2) and August 1994 (Chapter 3) serve as the foundation of this research. Both data sets were collected on the inner continental shelf off of Duck, NC. In July 1993, a 3-day time series of larval concentration was produced using 20- to $40-\mathrm{min}$ samples collected hourly at $0.8 \mathrm{~m}$ above the bed (mab) within $1 \mathrm{~km}$ of the shore ( 8 - $\mathrm{m}$ water column). Very little hydrographic information, other than water temperature, salinity and wind velocity, was available to 
aid in the interpretation of the observed variations in the larval concentration time series. In August 1994, a 3-wk time series of larval concentration was produced using 10-min samples collected at 3-hr intervals, 3 depths $(12.25,8.72$ and 3.20 mab), and at a $20-\mathrm{m}$ site $5 \mathrm{~km}$ from shore. Extensive hydrographic data were available for interpretation of physical processes potentially underlying the vertical and temporal patterns in larval concentration. Thus, the two data sets were obtained in different years and months, and at different heights above the bottom and inner shelf regions.

The 1993 study (Chapter 2) yielded four major conclusions. First, there was high temporal variability in concentrations of larval bivalves, gastropods, polychaetes, barnacles (cyprids) and bryozoans (cyphonautes). Larval concentrations changed by over two orders of magnitude in a several-hour period. Decorrelation times of 5-7 hr for the bivalves, gastropods, barnacles and bryozoans indicated that a minimum of $3-\mathrm{hr}$ sampling would be required to capture the majority of the variability in larval concentrations at this site. Higher-frequency $(<1 \mathrm{hr})$ sampling would be required for polychaete larvae.

Second, larval groups showed coherent variations in larval concentration over the 3-day study period. Although larval groups represented a diverse assemblage of organisms that settle intertidally and subtidally, as well as on hard and soft substrates, they appeared to be concentrated within a single patch (or within two patches). Thus, among-group variability was low, and all larval groups were transported in a similar way.

Third, high concentrations of larvae in all groups were associated with cooler water temperatures $\left(<15^{\circ} \mathrm{C}\right)$; no prominent peaks in larval concentration were observed 
in warm water. This suggests either that all groups were tracking with cool water masses from offshore, or that larvae had been concentrated on the cold-water side of the upwelling front (mechanism detailed in Epstein 1995).

Fourth, the arrival of larvae near the bottom $(0.8 \mathrm{mab})$ corresponded with periods of diminishing upwelling-favorable winds. During the cold-water period, near-bottom peaks in concentration also occurred near mid day. Thus, the observed variations in the larval concentration time series may have resulted from physical processes (e.g., relaxation of wind-driven upwelling) or larval behaviors (e.g., associations with specific water masses and diel vertical migrations within those water masses); several interpretations are possible with such a short time series collected at a single location.

The primary strengths of the 1993 study were that diverse larval groups were sampled, and that the decorrelation times were determined for these larval groups and will help guide sampling strategies for subsequent studies. For example, the decorrelation times for most larval groups indicated that the 3-hr sampling in the 1994 study was sufficient to capture the majority of the variability in larval concentration time series. The primary limitations of this study were the short length of the study period and the limited spatial resolution. A 3-day period covers a very small portion of a typical larva's life span (several weeks to several months) and a very limited range of physical conditions at the site. Furthermore, it is difficult to make generalizations based on time series of larval concentration collected at a single depth.

The 1994 study (Chapter 3) yielded four major conclusions. First, high concentrations of invertebrate larvae were documented for inner-shelf waters, but there 
was great temporal variability in the larval concentration time series. Biological oceanographers have noted that the variance associated with biological processes may be more ecologically relevant than mean values (e.g., Platt and Denman 1975; Gaines and Denny 1993), but few have examined the nature of such variations quantitatively because these analysis methods require long time-series data. Until recently, very few instruments could provide long time series of larval concentration. Within the context of the sampling regime, two dominant modes of variability were observed: one mode was associated with the synoptic meteorological time scale of 2-5 days, and the other was associated with the diurnal time scale.

Second, over relatively long time scales (of at least a week), larvae were associated with particular inner-shelf water masses defined by temperature-salinity characteristics. Larval polychaetes, bivalves and gastropods were more abundant in cooler, more-saline water masses below the thermocline, whereas crab zoea were more abundant in warmer, less-saline water masses. In addition, high concentrations of bivalve and gastropod larvae — possibly different assemblages of species — were occasionally found in warm water masses advected to the site during strong downwelling conditions. These findings indicate that physical processes that move water masses around, such as wind-driven upwelling and downwelling, will also move the larvae contained within those water masses in a similar and predictable way.

Third, vertical stratification of larvae within specific water masses was groupspecific, and was due to a combination of larval behaviors (i.e., diel vertical migration and vertical positioning relative to the thermocline). This means that larvae were passive 
to the degree that they were horizontally advected with certain water masses, but active to the degree that they could alter their vertical position in the water column.

Fourth, the interaction of local hydrodynamics, larval associations with specific water masses, and the vertical structure within those water masses could result in differential transport of larval groups to preferred adult habitats (see section 4.3).

The primary strengths of the 1994 study were the direct (versus inferred from settlement data) assessment of vertical structure in larval concentration, increased vertical coverage over a relatively long period of time (3-wks), and the linking of larval distributions with specific physical processes and larval behaviors. The primary limitations of this study were the limited larval stage and species information, the few independent realizations of upwelling and downwelling conditions, and the lack of consistent sampling above the thermocline.

\subsection{COMPARISON BETWEEN 1993 AND 1994 FIELD STUDIES}

The primary shared feature of the two data sets (1993 and 1994 studies) was the high variability observed in larval concentration time series. Despite the high variability, however, strong signals were exhibited. Variations were non-random. In both studies, the observed variability was likely attributed to either upwelling and downwelling conditions, or diel vertical migration, or both.

Two major differences were observed between the 1993 and 1994 data sets. First, the range in concentration differed substantially. The ranges in 1993 were $0-668 \mathrm{~m}^{-3}$ for polychaetes, $0-516 \mathrm{~m}^{-3}$ for bivalves, $6-414 \mathrm{~m}^{-3}$ for gastropods, $5-746 \mathrm{~m}^{-3}$ for barnacle 
cyprids, and $0-86 \mathrm{~m}^{-3}$ for bryozoan cyphonautes. The ranges in 1994 were $0-11,576$ $\mathrm{m}^{-3}$ for polychaetes, $16-9,780 \mathrm{~m}^{-3}$ for bivalves, $0-6,756 \mathrm{~m}^{-3}$ for gastropods, and $0-352$ $\mathrm{m}^{-3}$ for zoea. Thus, the maximum concentrations of larvae observed in the two years differed by a factor of about 20 .

Second, the degree of among-group variability in larval concentration differed between the 1993 and 1994 studies. In the 1993 study, among-group variability in larval concentration was relatively low. All taxonomic groups showed coherent peaks within a period when cool water was present at the site. The observed coherence among groups means that differential transport among groups is unlikely. All groups moved to the bottom nearly simultaneously. In contrast, in the 1994 study, among-group variability in larval concentration was relatively higher. Larvae remained vertically stratified in different water masses and at different depths relative to the thermocline. On the other hand, diel vertical migration patterns were generally similar for all groups except brachyuran crab zoea.

Differences in the biological response (i.e., maximal larval concentrations and among-group variability) during the two studies may be due to the following factors: (1) data sets were collected during different years (1993 versus 1994) and months (July versus August); (2) data sets were collected at different heights above the bottom ( 0.8 versus $3.2 \mathrm{mab}$ ) and different regions of the inner shelf ( 1 versus $5 \mathrm{~km}$ offshore, and in water columns 8 versus $20 \mathrm{~m}$ deep); and (3), time series data sets were of different lengths ( 3 days versus 3 weeks). Thus, it is difficult to determine whether the different patterns exhibited in the time series can be attributed to temporal issues or spatial issues. 
Different species assemblages may have been sampled during the two seasons. Moreover, the 3-day sampling period in 1993 may not have covered the range of variability in larval concentration that existed at the site. Comparing patterns of variability between the two studies is appropriate if the low concentrations observed in 1993 were the result of seasonal differences in fecundity; however, it would be inappropriate if the two studies covered different portions of the variability spectrum. Because of these confounding temporal issues, it is difficult to determine whether the effects of physical or biological processes on larval distributions were expressed differently at inshore versus offshore regions.

A more informative comparison to address some of the spatial issues would involve the differences observed in larval concentration time series at the 8-m versus 20$\mathrm{m}$ sites in 1994. Likewise, a more informative comparison to address some of the temporal issues would involve the differences observed in larval concentration time series at the 8-m site in 1993 versus 1994.

\subsection{RECOMMENDATIONS FOR FUTURE RESEARCH}

This thesis research is largely descriptive. In addition to providing information on temporal and spatial patterns, which can have important ecological implications for differential growth, mortality and transport, this research has also generated specific questions that can be addressed in future research. Because of the time required to sort a single plankton sample, it is desirable to minimize the number of samples required to test 
a specific hypothesis. This research has identified the times and places to sample in the water column as well as near the bottom.

Comparison between the 1993 study conducted at $1 \mathrm{~km}$ from the coast, and the 1994 study conducted at $5 \mathrm{~km}$ from the coast suggested that among-group variability in larval concentration may be reduced at the inshore site. There were confounding temporal and spatial issues, however, that prevented us from making generalizations regarding the differences between the two inner-shelf sites using these data. Comparisons between additional time series collected during the CoOP94 field study (see Chapter 1, section 1.4) could be used to address whether larval distributions are controlled differently by the dynamics of inshore versus offshore regions of the inner shelf. Specifically, a comparison between the synoptic larval concentration time series collected at the inshore ( $8-\mathrm{m}$ site $1 \mathrm{~km}$ from the coast) and the $20-\mathrm{m}$ ( $5 \mathrm{~km}$ from the coast) sites could be used to test whether there are dynamically different regions of the inner-shelf which generate differential among-group variability.

Vertical patterns of larval distributions have been described. Yet, only the coupling between these distribution patterns and the transport associated with upwelling and downwelling conditions has been explored. A natural extension of this work would be to assess or model the influence of other advective processes that move heat and water masses containing larvae around in the inner-shelf region. For example, larvae distributed near the thermocline may be susceptible to shoreward movement by breaking internal tidal bores (e.g., Pineda 1991). 
The origin of several sub-groups of larval bivalves and gastropods could not be determined with these data. Concentration time-series of larval species data may elucidate the origin of these larvae. For example, are there different warm-water and cold-water species assemblages? If so, where are they coming from? Are planktonic distributions reflective of the inshore versus offshore adult habitats of these larvae? Additionally, what are the alongshore versus cross-shelf contributions to the assemblage of species at the site? Additional knowledge of larval origin is necessary to augment our understanding of the planktonic processes underlying differential transport and recruitment variability of benthic invertebrate species.

Two dominant modes of variability have been identified in the larval concentration time-series data: a relatively "low-frequency" mode associated with the synoptic meteorological time scale (of order 2-5 days) and a relatively "high-frequency" (diurnal) mode. But, the separation between these two time scales of variability is artificial and purely logistical. A natural extension of this work would be to quantify how processes occurring at these two scales are coupled, and to what degree they influence recruitment variability. For example, do recruitment time series exhibit variations reflective of processes operating at both scales? Of the larvae settling and recruiting into benthic populations, what is the relative contribution of the larvae arriving at a site via high-frequency (diurnal) processes, low-frequency (upwelling) processes, or episodic (very strong downwelling) events?

The long-term goal is to elucidate the coupling between variability in planktonic larval availability and variability in larval settlement and recruitment into benthic 
populations. This thesis research has identified the times during which and the subtidal places at which larvae have the opportunity to contact the bottom (Chapter 3, section 3.5). Accordingly, the times and places of maximal recruitment can be predicted. The cold-water sub-groups of bivalve and gastropod larvae are predicted to recruit episodically during strong downwelling events, or on time scales associated with ontogenetic or diel vertical migration. The warm-water sub-groups of bivalve and gastropod larvae are predicted to recruit during strong downwelling events. The coldwater polychaete larvae are predicted to recruit on synoptic meteorological time scales or time scales associated with ontogenetic or diel vertical migration. Recruitment of the cold-water sub-groups of larval bivalves, gastropods and polychaetes is predicted to occur over a wide span of subtidal inner-shelf habitats. In contrast, the recruitment of warm-water sub-groups of larval bivalves, gastropods and brachyuran crabs is predicted to be concentrated at of the point where the downwelled thermocline intersects the bottom. The offshore extent of this point changes constantly depending upon the meteorological and hydrographic conditions, but typically does not go beyond $7-10 \mathrm{~km}$ offshore (Waldorf et al. 1995). Thus, recruitment in these groups is expected to be concentrated inshore of $7 \mathrm{~km}$. In deeper waters farther offshore, the downwelled thermocline may never intersect the bottom and larvae would arrive at the bottom only during deep mixing events which generally occur later in the season, or through other behavioral processes (e.g., vertical migration), although the muddy bottom of deeper waters is not a preferred adult habitat for the majority of the species within these groups (Gosner 1979). 
Management of commercially important invertebrate species can focus on maximizing survival of adults in the population, or maximizing larval recruitment into the population. In the later case, management requires an understanding of the times and places where recruitment is expected to be maximal and the processes underlying the observed variations in time and space. Maximizing larval recruitment can be facilitated, for example, by deploying aquaculture spat collectors or predator-exclusion cages at the predicted times and places of maximal larval supply.

\subsection{LITERATURE CITED}

Epstein AW (1995). Physical processes and zooplankton distribution in the Great South Channel: observational and numerical studies. MIT/WHOI Joint Program in Oceanography. Ph.D. Dissertation. MIT/WHOI 95-09.

Gosner KL (1979). Guide to Identification of Marine and Estuarine Invertebrates. Cape Hatteras to Bay of Fundy. Wiley-Interscience, NY.

Pineda J (1991). Predictable upwelling and the shoreward transport of planktonic larvae by internal tidal bores. Science 253: 548-551.

Waldorf BW, Largier JL, Rennie S, Austin J, Greengrove S (1995). Coastal Ocean Processes (CoOP) pilot project data report: R/V Cape Hatteras shipboard measurements; underway CTD and ADCP data, August 1994. Scripps Inst. Oc. Ref. Ser. No. 95-29 


\section{APPENDIX A}

Techniques for the Identification of Bivalve Larvae 


\section{A.1 INTRODUCTION}

Research that focuses on the role of the larval stage in population, community and ecosystems ecology has been greatly hindered by two major technological limitations in quantifying planktonic larval distributions (e.g., Scheltema 1986; Butman 1987; Levin 1990). The first limitation has been obtaining large numbers of samples with adequate spatial and temporal coverage, especially relative to the sampling of physical and chemical variables. Extensive sampling is required because larval distributions are notoriously patchy in both space and time, due in large part to physical transport processes as well as other physical, biological and chemical interactions in the plankton.

The second limitation in quantifying planktonic larval distributions has been processing the large numbers of samples generated by extensive field surveys. Longterm, moored time-series collections of invertebrate larvae are now possible (Butman 1994); however, processing steps remain cumbersome. Weeks of intensive plankton sampling can lead to several years of full-time sample processing. At present the only technique available for reliable species identification is direct microscopic observation, and even this is limited to larval stages and species that can be distinguished morphologically (see section A.2). Many of the youngest larval stages, particularly of the bivalves which are frequently the most abundant invertebrate larvae in coastal samples, look so similar in their early development that they cannot be identified definitively to species using gross morphological criteria alone (e.g., Loosanoff et al. 1966; Chanley and Andrews 1971; Le Pennec 1980). Ignoring these early larval stages or lumping them into 
supra-specific categories may limit the management potential as well as the scientific questions that can be meaningfully addressed with field data. Shellfisheries management, for example, is usually directed at a few key, commercially important organisms, and species-specific information on the distributions of the targeted species' planktonic larvae is needed for understanding the causes of recruitment variation (e.g., Mann 1988;

Weinberg 1993; Ma et al. 1999).

Molecular methods (e.g., antibody and oligonucleotide probes) lend considerable promise for identifying bivalve larvae to species, regardless of developmental stage, thereby alleviating some of the ambiguity or subjectivity of traditional, morphologybased taxonomy and eventually expediting sample-processing procedures (see sections A.3 - A.4). Yet, there are tradeoffs in specificity, efficiency and costs at this time. All approaches - morphological or molecular — require information on sympatric species in order to identify species-specific characters (e.g., morphological features, genes or proteins). Furthermore, all approaches are sensitive to organism damage and preservation artifacts (France and Kocher 1996; Dawson et al. 1998).

Presently, definitive identification of bivalve larvae requires that larvae be sampled directly so that morphological or molecular techniques can be applied. Acoustic (e.g., Holliday 1980; Pieper and Holliday 1984; Greene and Wiebe 1990) and other remote-imaging technologies (e.g., Ortner et al. 1981; Dickey 1988; Davis et al. 1992a; Herman 1992), were not designed for the identification of invertebrate larvae to species. For example, sound scattering (using acoustics) is not likely to vary sufficiently among morphologically similar species in this small size range to yield unique target strengths. 
Optical techniques may be more useful in studies involving bivalve larvae when coupled with other technologies such as molecular markers (see section A.5).

Thus, recent leaps in technology development for automated, direct, time-series collections of planktonic larvae have considerably out-paced technology development for efficient and accurate enumeration and identification of these animals to species. Identification of species is crucial because species-specific behavioral differences in planktonic larvae have been invoked to explain gradients in adult distributions (e.g., Hannan 1981; Grosberg 1982; Caffey 1985; Shanks and Wright 1987).

An original objective of this thesis research was to develop immunofluorescent probes for the identification of bivalve species. This tool would have allowed me to address the questions of whether time series of bivalve concentration with increased taxonomic resolution (i.e., identification of larvae to species versus major taxonomic groupings) exhibit a stronger signal and correlate better with hydrographic variables, and whether species-specific distributions in space and time would result in delivery of these organisms to preferred adult habitats and niche-separation. The development of immunofluorescent probes was unsuccessful, however, due to a lack of cooperation by the biotech firm contracted to isolate species-specific proteins in the bivalve larvae, as well as to other factors. The proposed approach (see section A.3) was never evaluated. Thus, the proposed antibody methods, as well as other methods of bivalve larval identification, are discussed herein to help assist future research involving the identification of bivalve larvae. 


\section{A.2 MORPHOLOGICAL TECHNIQUES}

Microscopic examination remains the most reliable technique for identification of bivalve species, though the subjectivity associated with this approach renders it somewhat problematic. Microscopic examination requires comparisons between sampled larvae and voucher collections (e.g., preserved specimens, drawings, or photographs of larvae of known origin). Yet, there are over 200 species of bivalves found off the east coast of the United States (Gosner 1979), and the larval stage has been described for less than one quarter of these species. Moreover, certain genera contain many species. For example, there are at least sixteen species in the genus Tellina, but the larvae of only one species, Tellina agilis, has been described. Comparison of morphological features among sympatric species is required for definitive species identification.

Early research on the identification of European and Japanese (e.g., Lebour 1938, Werner 1939; Jorgensen 1946; Rees 1950, Yoshida 1953 and 1957; Zakhuatkina 1959; Miyazaki 1962) and North American (e.g., Stafford 1912; Sullivan 1948) bivalve larvae was mostly descriptive, as opposed to comparative. More recent keys by Loosanoff, et al. (1966) and Chanley and Andrews (1971) provide detailed information and comparisons among various species. According to these guides, bivalve larvae can be classified based on differential shape, dimensions, hinge-line length, umbone character and color. Yet, most bivalve larvae look morphologically similar at the early, straighthinged stage; and some groups remain morphologically indistinguishable even at later stages. Thus, the targeted morphological characteristics at early stages are generally 
insufficient for definitive species identification. Phenotypic plasticity also renders morphology-based identifications problematic. For example, the expression of many morphological characters is dependent upon environmental conditions, such as food concentration and water temperature (Boidron-Metairon 1988; Strathmann et al. 1992; Shirley et al. 1987).

Due to high variability associated with the expression of the targeted morphological characters, invariant morphological characters were sought for definitive identification to species. Werner (1939) and Rees (1950) were the first to note the uniqueness of each species' hinge structure (i.e., shape and placement of hinge "teeth"; Loosanoff et al. 1966), even at the straight-hinge stage. Visualizing the hinge structure became easier with the use of Scanning Electron Microscopy (SEM; e.g., Turner and Boyle 1975; Lutz and Jablonski 1978; Lutz and Hidu 1979; LePennec 1980; Lutz et al. 1982; Fuller et al. 1989). These techniques require, however, the disarticulation of shells from individual larvae, and the meticulous leveling of shells before being viewed under the scanning electron microscope. Thus, the time and costs associated with this method may severely limit the number of larvae that can be evaluated.

Regardless of the chosen resolution (i.e., higher resolution of SEM or lower resolution of light microscopy), a certain degree of subjectivity is involved with morphological identifications, and there is a tendency to assign names that exist in taxonomic keys (i.e., versus leaving an organism nameless). Reliance on morphological criteria alone in species identifications means that the accuracy of identifications depends on the level of expertise of the identifier, and that precision may be sacrificed when 
identifications are made by more than one person. Molecular methods (i.e., antibody and oligonucleotide probes) have the potential to decrease subjectivity and increase accuracy and precision of species identifications.

\section{A.3 IMMUNOLOGICAL TECHNIQUES}

Immunological techniques for recognizing species in mixed populations capitalize on the occurrence of unique, diagnostic, "signature proteins" (or portions thereof) within a given species. These proteins, when injected into a vertebrate host (such as a mouse or rabbit), are regarded as "foreign" and an immune response is triggered within the host. During this response, the host releases antibodies in order to confer immunity to the foreign substances ("antigens") in the blood stream. These newly expressed antibodies recognize and bind exclusively to their homologous signature antigen (in this case, the larval protein). The unique target (i.e., on the larval antigen) of a specific antibody is generally referred to as an "epitope". Repeated injections of the antigen or epitope into the vertebrate host (hyperimmunization) results in accelerated antibody production within the host. Immunostimulants and protein expression vectors are added to the injection mixture to maximize the immune response.

Using well-documented biochemical techniques, antibodies formed in this manner can be isolated from the host, purified, and tagged with fluorochromes or other appropriate reporter markers which can be detected visually (e.g., Harlow and Lane 1988; Beltz and Burd 1989). These tagged antibodies will recognize the complementary antigen(s) to which they were produced. Obtaining species-specific antibody probes is 
contingent, however, on finding an epitope that is unique to one particular species. Ideal targets include epitopes that are conserved within a single species, regardless of its developmental stage or physiological state, but are not conserved among other closely related species.

Application of immunological techniques to address research questions in biological oceanography and recruitment is relatively new (e.g., reviews of Bohlool and Schmidt 1980; Yentsch et al. 1988; Powers et al. 1988 and 1990; Ward 1990). The most extensive, early immunochemical applications were for food-web analyses - that is, for identifying taxa in macerated gut contents (e.g., Feller et al. 1979; Feller and Gallagher 1982). Although trophic groups usually were distinguished, the antibodies produced in these studies provided limited taxonomic resolution, which was rarely lower than order or family due to extensive antibody cross-reactions among species. More recent developments in protein isolation and antibody purification procedures indicate promise in ultimately identifying to species both single cell (e.g., Dahle and Laake 1982; Campbell et al. 1983; Ward and Carlucci 1985) and multi-cellular organisms (e.g., Shapiro et al. 1989; Ohman et al. 1991; Campbell et al. 1994), including planktonic larvae of benthic invertebrates (e.g., Miller et al. 1991; Demers et al. 1993; Hanna et al. 1994).

The ultimate degree of specificity of the antibodies produced was low in both the early food-web studies and the studies on invertebrate larvae, because none of these studies targeted a species-specific protein for use in production of antisera. Rather, whole organisms (i.e., versus a specific signature protein) were homogenized and used to 
inoculate the host vertebrate. Within the protein complement of the homogenized organism, the majority of the proteins are shared across supra-specific taxonomic groups and a much smaller number of proteins are species-specific.

After the multiple antigen injections had triggered an immune response producing thousands of antibody types, polyclonal (in the food-web studies and Demers et al. 1993) and monoclonal (Miller et al. 1991; Hanna et al. 1994) antibodies were selected that showed the least reactivity with other, non-targeted organisms. The resulting polyclonal antibodies were successful as genus- and (mostly) higher-taxon-specific markers, commensurate with the initial goals of these groundbreaking studies, but were not reliable species-specific markers because of marked cross-reactions with other species. The monoclonal antibodies were more successful in terms of species-specificity, but at considerable initial cost in terms of time and expense. The monoclonal procedure involved culturing large numbers of isolated cell lines and assaying for the clones showing minimal reactivity with non-targeted species. Distinguishing barnacle larval species in the most successful case thus far (Miller et al. 1991) still involved application of antibodies in two steps to separate three species via binary visual comparisons.

The advantages of polyclonal antibodies are higher affinity, wider reactivity, longer shelf life, simpler production techniques once the antigen has been purified, and lower overall production costs in terms of both time and money. Yet, unless the injected antigen is species-specific, specificity of polyclonal antibodies are generally inadequate for species identifications without purifying them further using adsorption, affinity chromatography or blocking techniques (e.g., Buchmann et al. 1992; Mendoza et al. 
1995; Costas and Lopez-Rodas 1996). The advantages of monoclonal antibodies are large-scale production (using tissue culture methods), high specificity, and lack of the need to purify the antigen because initial screening for species-specificity occurs after antibody production in the host (Beltz and Burd 1989). Monoclonal antibodies are notoriously fickle, however. Because they are so specific, however, their application can be compromised by any slight degradation of the epitope. Refinements to the monoclonal antibody technique (e.g., creating multiple monoclonal antibody "cocktails") may well yield the desired species-specificity and shelf life for larval probes.

Many studies have applied polymorphic allozyme electrophoresis techniques to discriminate among species of adult bivalves (e.g., Beaumont et al. 1989; McDonald et al. 1991; Benzie and Williams 1998). Hu et al. (1992) adapted these techniques to successfully discriminate among larvae of three oyster species. Hence, if one- or twodimensional electrophoresis can be used to isolate species-specific general proteins or allozymes, it follows that these proteins or allozymes may be excised from electrophoretic gels and used to inoculate a vertebrate host. In fact, this was the approach we (Butman and Garland) originally proposed for the development of species-specific probes for bivalve larvae. Because of personnel problems, this technique was never evaluated, however, and thus the approach remains promising. Immunofluorescent markers developed in this way may not possess most of the known disadvantages of antibody probes, such as limited yield of monoclonal antibodies, difficulty in producing species-specific antisera, high degree of cross-reactivity, and the effort required to maintain tissue cultures required for the production of monoclonal antibodies. Polyclonal 
antibodies developed against a defined epitope should provide adequate sensitivity and specificity, and are a fraction of the cost of monoclonal antibodies (e.g., Macario et al. 1983; Harlow and Lane 1988). The ultimate drawback of antibody probes, in general, is that larval proteins may be highly conserved and thus may not be sufficiently different between species to be used as species-specific markers. Isolating a species-specific protein represents the ultimate challenge. Furthermore, antibody probes are highly dependent on larval preservation status, age, stage or physiological state.

\section{A.4 GENETIC TECHNIQUES}

The deoxyribose nucleic acid (DNA) of an organism represents a molecule that is endogenously fixed, and mostly invariant with larval age, stage, or physiological state. Thus, DNA has been a target for species-specific probe development for a number of plants and animals (see reviews of DeLong 1989; Stahl and Amann 1991; Amann et al. 1995), including larval invertebrates (e.g., Olson et al. 1991; Banks et al. 1993; Geller et al. 1993; Geller 1996; Coffroth and Mulawka 1995; Medeiros-Bergen et al. 1995; Ó Foighil et al. 1995; 1998; Bell and Grassle 1997 and 1998; Toro 1998; André et al. 1999; Frese et al. submitted; Hare et al. in prep.; J.P. Grassle and P. Nelson, unpubl. results).

The design of both immunochemical and oligonucleotide probes involves a similar strategy in that "signature molecules" unique to a particular species are identified and isolated. In genetic approaches, the signature molecule is a small sequence of nucleic acid (DNA or RNA), whereas in immunochemical approaches the signature molecule is a

product of gene expression (usually proteins). Ultimately, the success of either technique 
hinges on knowledge of sympatric species' protein or genetic makeup, and the uniqueness of the targeted molecules.

The development of DNA probes involves identifying a unique gene sequence highly conserved within a bivalve species yet not conserved among closely related bivalve species. DNA must first be extracted from as many sympatric bivalve species as possible, amplified using the Polymerase Chain Reaction (PCR), and sequenced. Unique nucleic acid sequences can then be identified through cross-comparisons of sympatric species' gene sequences (Rice 1990; Rice et al. 1993), and labeled for probe production (Hockfield et al. 1993). Mitochondrial DNA (mtDNA) is highly conserved in terms of both sequence similarity and gene length, and thus is often targeted for slight gene differences among closely related groups. For bivalves, two regions of the mitochondrial genome have been the primary targets for probe development: the ribosomal RNA genes (rDNA) and the cytochrome $c$ oxidase subunit I gene (COI), with the former being more highly conserved.

Banks et al. (1993), Geller et al. (1993), and Ó Foighil et al. (1995) targeted mitochondrial $16 \mathrm{~S}$ ribosomal RNA (16S rDNA) genes in oysters and mussels, but found that this gene had not diverged adequately to differentiate among congeners. A two-step PCR / restriction fragment length polymorphism (RFLP) technique was necessary to differentiate among species. Likewise, the DNA probes developed by Bell and Grassle (1997 and 1998) targeting a sequence within the 18S ribosomal RNA gene (18S rDNA), were determined to be family-specific for Mactrid bivalves (e.g., Spisula solidissima (surf 
clam) and Mulinia lateralis) but not species-specific. Species-specific discrimination required a two-step PCR/ RFLP analysis (Bell and Grassle 1998).

The mitochondrial cytochrome $\mathrm{c}$ oxidase subunit I (mtCOI) gene also has been targeted for probe development since universal primers were developed by Folmer et al. (1994). This region has shown species-specific variation for other organisms (Palumbi and Benzie 1991), as opposed to the family-specific variation observed in the $18 \mathrm{~S}$ ribosomal DNA gene (e.g., Kenchington et al. 1994; Adamkewicz et al. 1997). The mtCOI gene was used to identify the origin of oysters thought to be anthropogenically transferred as larvae in ballast water (Ó Foighil et al. 1998). It was also used successfully to differentiate among five species of freshwater mussels using the combined PCR / RFLP approach (Baldwin et al. 1996). DNA probes that target this gene have been developed recently for Mya arenaria (soft-shelled clam), Mercenaria mercenaria (quahog or hard-shelled clam), Argopecten irradians (bay scallop). Spisula solidissima (surf clam) and Mulinea lateralis (Frese et al. submitted; Hare et al. in prep).

Despite their high cost of production, oligonucleotide probes can be produced to any degree of specificity, given that the proper gene sequence is targeted. This approach looks promising, especially if the techniques become more automated in the future.

\section{A.5 AUTOMATED OPTICAL TECHNIQUES}

Within the field of marine science, image-analysis techniques have been used to determine the biomass of planktonic organisms (e.g., Bjørnsen 1986; Sieracki and Viles 1990; Bittner 1998) and to determine their sizes and shapes (e.g., Gevirtz 1976; Jeffries et 
al. 1984; Estep and MacIntyre 1989; reviewed in Fawell 1976 and Berman 1990). Furthermore, optical-digital identifications have been successful for certain groups of phytoplankton (e.g., Pech-Pacheco and Alvarez-Borrego 1988; Culverhouse et al. 1996; McCall et al. 1996) and zooplankton (Gallager et al. 1996a). Species-specific identification of the majority of larval bivalves is unlikely at this time, however, because species-specific characters are generally found at the microscopic (i.e., morphological) or biochemical (i.e., proteins or nucleic acids) level. Furthermore, imaging morphological characters and dimensions is highly dependent upon the orientation of the specimen - a factor not easily controlled in situ (Fuller et al. 1989). Thus, direct sampling of bivalve larvae is generally required for species-specific identification.

Instead, the strength of automated optical techniques in larval studies involving identification of bivalve larvae is manifest in ecological questions where whole groups of organisms are targeted, in automated enumeration applications, or in coupling optical techniques with molecular tagging procedures (i.e., automated identifications; Amann et al. 1990a). By attaching fluorescent reporter tags that emit at a given wavelength of light (once excited by a given wavelength) to species-specific molecular probes, different species within a sample can be color-coded. For example, species $A$ can be labeled with a fluorescein-conjugated probe, species $B$ can be labeled with a rhodamine-conjugated probe and species $C$ can be labeled by a resorufin-conjugated probe. These fluorochromes have excitation spectra generally in the range from $312-365 \mathrm{~nm}$ (Molecular Probes, Eugene, OR), and therefore can be visualized as blue, green-yellow and red emitted light, respectively, with a single wide-band excitation source (Harlow 
and Lane, 1988; Recktenwald, 1992). Thus species $A, B$ and $C$ can be readily differentiated by their colors, and an image-analysis system can be used to automate the process.

\section{A.6 PERSPECTIVE:}

Microscopic techniques are advantageous because much of the traditional taxonomy of bivalve molluscs has been based on morphological differences. Yet, as in other taxonomic groups, molecular techniques may provide new criteria for more reliable classification. This will make comparisons difficult among studies using morphologybased and molecular-based identifications.

Immunofluorescent and oligonucleotide probes have their advantages and disadvantages; some applications are complementary (e.g., Macario and Conway de Macario 1983; Powers et al. 1990), especially when used in concert with traditional assays. Ideally the most time and cost-effective marker techniques for the particular purpose of automated processing of large-numbers of field samples of planktonic organisms should: (1) involve no direct sorting of organisms from a sample (i.e., instead, the probe would be applied to a multi-species assemblage in a small dish); (2) be effective on intact, whole organisms; (3) result in a sufficiently colorful surface expression on the organism for detection via color image-analysis techniques (i.e., for automated counting and sizing); (4) be relatively inexpensive to develop (i.e., so that such probes ultimately can be generated for a large number of species); (5) be relatively inexpensive to produce once developed; and (6) produce repeatable results. 
Because antibody probes can be applied to whole organisms within a sample, the animals can be sized simultaneously with the image-analysis system and saved in voucher collections for other analyses (e.g., basic morphometrics). The primary disadvantages include the requirement of extracting protein from larvae of numerous bivalve species (often difficult to raise or acquire), the lack of specificity, and highly variable results because these probes bind to larval proteins and protein expression is dependent upon a suite of endogenous and exogenous factors.

Oligonucleotide probes have the advantages of being developed using tissue from adult organisms which are much easier to obtain. They can also be so specific that they can even be produced to identify individuals within a given population (e.g., human fingerprinting as in Jeffreys et al. 1985), which can be viewed as an asset or a liability depending upon the scientific questions addressed. Application of some types of oligonucleotide probes (e.g., dot blot methods, as in Silberman and Walsh 1992; PCR methods as in Cary et al. 1993; Olson et al. 1991 Medeiros-Bergen et al. 1995), however, requires destructive processing of the organisms or parts of the organisms. Although in situ oligonucleotide probes do not destroy the organisms (DeLong et al. 1989; Amann et al. 1990b, 1995), the organisms still must be individually isolated from samples before testing.

More documentation is needed, however, on how the DNA of local populations is affected by interspecific hybridization (Gaffney and Allen 1993) and the introduction of non-endemic congeners (Carlton 1985; Carlton and Geller 1993; Geller 1996). For example, contamination from aquaculture hatchery stocks is becoming widespread 
worldwide (Naylor et al. 1998) and could lead to the corruption of local population's gene pool.

The high degree of specificity makes oligonucleotide probes desirable and worth their cost, for example, in tracking the dispersal of organisms originating from a particular population (e.g., Bucklin 1992; Martin et al. 1992); in difficult species identifications or tracking relatively rare larvae that can be easily sorted from plankton samples (e.g., Olson et al. 1991; Bell and Grassle 1998); in biodiversity studies (DeLong et al. 1993); and whenever targeted material is available in limited supply and the DNA must be amplified by the PCR (e.g., Giovannoni 1991; Cary et al. 1993), such as when a single larva is isolated from the deep sea (e.g., E. Agenbroad and S.C. France pers. comm.). Oligonucleotide probes may be cost-ineffective and more specific than required, however, for large-scale identification of a species across its geographic range. Thus, immunochemical methods may be preferable in broader-scale applications (e.g., for determining planktonic larval distributions), when it is not feasible or practical to sort all larvae individually from samples, when targeted material is available in large amounts or can be easily cultured in the laboratory during development of the probe, and when cost is a consideration. Immunofluorescent tagging methods are operable on whole organisms, and the organisms need not be sorted from the sample individually.

The ability to detect optically, distinguish among, and enumerate dissimilarly colored dots (i.e., the tagged larvae) is a straightforward, well-described application of image analysis technology (e.g., Bjørnsen 1986; Sieracki and Viles 1990; Amann et al. 1990; reviewed in Inoue 1986; Berman 1990), and it is the logical next step to couple this 
technology with the types of molecular probes discussed herein. The greatest challenge in these fields is to streamline the technology involved in the application of molecular probes. 


\section{A.7 ACKNOWLEDGEMENTS}

I thank Rich Lutz and Alan Pooley (Institute of Marine Science, Rutgers University) for instruction on the identification of bivalve larvae using Scanning Electron Microscopy (SEM) techniques. Attempts to develop immunofluorescent identification techniques were made on bivalve larvae cultured at WHOI and elsewhere by Aquacultural Research Corporation (ARC, Dennis, MA), Beal's Island Shellfish Hatchery (Beal's Island, ME), Harbor Life (Nantucket, MA), Martha's Vineyard Shellfish Group (Martha's Vineyard, MA), Mook Sea Farms (Damariscotta, ME), and Taylor Seafood (Fairhaven, MA).

This research was supported by grants from the NOAA National Sea Grant Program Office, Department of Commerce (Grant \# NA46RG0470, Woods Hole Oceanographic Institution Sea Grant Project Numbers, RB-132 and RB-139 to Cheryl Ann Butman and Elizabeth D. Garland). 


\section{A.8 LITERATURE CITED}

Adamkewicz SL, Harasewych MG, Blake J, Saudek D, Bult CJ (1997). A molecular phylogeny of the bivalve mollusks. Mol. Biol. Evol. 14: 619-629.

Amann, RI, Binder BJ, Olson RJ, Chisholm SW, Devereux R, Stahl DA (1990a). Combination of $16 \mathrm{~S}$ rRNA-targeted oligonucleotide probes with flow cytometry for analyzing mixed microbial populations. App. Environ. Microbiol. 56: 1919-1925.

Amann, RI, Krumhulz L, Stahl DA (1990b). Fluorescent-oligonucleotide probing of whole cells for determinative, phylogenetic, and environmental studies in microbiology. J. Bact. 172: 762-770.

Amann RI, Ludwig W, Schleifer K-H (1995). Phylogenetic identification and in situ detection of individual cells without cultivation. Micro. Rev. 59: 143-169.

André C, Lindegarth, Jonsson PR, Sundberg P (1999). Species identification of bivalve larvae using random amplified polymorphic DNA (RAPD): differentiation between Cerastoderma edule and C. lamarcki. J. Mar. Biol. Assoc. U.K. 79: 563-565.

Baldwin BS, Black M, Sanjur O, Gustafson R, Lutz RA, Vrijenhoek RC (1996). A diagnostic molecular marker for zebra mussels (Dreissena polymorpha) and potentially co-occurring bivalves: Mitochondrial COI. Mol. Mar. Biol. Biotechnol. 5: 9-14.

Banks MA, Hedgecock D, Waters C (1993). Discrimination between closely related Pacific oyster species (Crassostrea) via mitochondrial DNA sequences coding for large subunit rRNA. Molec. Mar. Biol. Biotechnol. 2: 129-136.

Beaumont AR, Seed R, Garcia-Martinez P (1989). Electrophoretic and morphometric criteria for identification of the mussels Mytilus edulis and $M$. galloprovincialis. In: Ryland JS and Tyler PA (eds.), Reproduction, Genetics and Distributions of Marine Organisms. Olsen and Olsen, Denmark, pp. 251-258.

Bell JL, Grassle JP (1997). Preparation of DNA from numerous individual microscopic organisms for PCR-based assays of environmental samples. Biotechniques. 23: 584-588.

Bell JL, Grassle JP (1998). A DNA probe for the identification of larvae of the commercial surfclam (Spisula solidissima). Molec. Mar. Biol. Biotechnol. 7: 127-137.

Beltz BS, Burd GD (1989). Immunocytochemical Techniques: Principles and Practice. Blackwell, Cambridge, MA. 
Benzie JAH, Williams ST (1998). Phylogenetic relationships among giant clam species (Mollusca: Tridacnidae) determined by protein electrophoresis. Mar. Biol. 132: 123133.

Berman MS (1990). Application of Image Analysis in demographic studies of marine zooplankton in large marine ecosystems. In: Sherman K, Alexander LM, and Gold BD (eds.), Large Marine Ecosystems. Patterns, Processes and Yields. American Association for the Advancement of Science, Washington, DC, pp. 122-131.

Bittner C, Wehnert G, Scheper T (1998). In situ microscopy for on-line determination of biomass. Biotechnol. Bioeng. 60: 24-35.

Bjørnsen PK (1986). Automatic determination of bacterioplankton biomass by image analysis. Appl. Environ. Microbiol. 51: 1199-1204.

Bohlool B, Schmidt EL (1980). The immunofluorescence approach in microbial ecology. Adv. Microbiol. Ecol. 4: 203-241.

Boidron-Métairon IF (1988). Morphological plasticity in laboratory-reared echinoplutei of Dendraster excentricus (Eschscholtz) and Lytechinus variegatus (Lamark) in response to food conditions. J. Exp. Mar. Biol. Ecol. 119: 31-41.

Buchmann K, Østergaard L, Glamann J (1992). Affinity purification of antigen specific serum immunoglobulin from the European eel (Anguilla anguilla). Scand. J. Immunol. 36: 89-97.

Bucklin A, Frost BW, Kocher TD (1992). DNA sequence variation of the mitochondrial 16S rRNA in Calanus (Copepoda; Calanoida): Intraspecific and interspecific patterns. Mol. Mar. Biol. Biotechnol. 1: 397-407.

Butman CA (1987). Larval settlement of soft-sediment invertebrates: The spatial scales of pattern explained by active habitat selection and the emerging rôle of hydrodynamical processes. Oceanogr. Mar. Biol. Ann. Rev. 25: 113-165.

Butman CA (1994). CoOP, Coastal Ocean Processes Study: Interdisciplinary approach, new technology to determine biological, physical, geological processes affecting larval transport on the inner shelf. Sea Technol. 35: 44-49.

Caffey HM (1985). Spatial and temporal variation in settlement and recruitment of intertidal barnacles. Ecol. Monogr. 55: 313-332.

Campbell L, Carpenter EJ, Iacono VJ (1983). Identification and enumeration of marine chroococcoid cyanobacteria by immunofluorescence. Appl. Environ. Micro. 46: 553559 . 
Campbell L, Shapiro LP, Haugen E (1994). Immunochemical characterization of eukaryotic ultraplankton from the Atlantic and Pacific oceans. J. Plankton Res. 16(1): $35-51$.

Carlton JT (1985). Transoceanic and interoceanic dispersal of coastal marine organisms: The biology of ballast water. Oceanogr. Mar. Biol. Ann. Rev. 23: 313-371.

Carlton JT, Geller JB (1993). Ecological roulette: The global transport of nonindigenous marine organisms. Science. 261: 78-82.

Cary SC, Warren W, Anderson E, Giovannoni SJ (1993). Identification and localization of bacterial endosymbionts in hydrothermal vent taxa with symbiont-specific polymerase chain reaction amplification and in situ hybridization techniques. Mol. Mar. Biol. Biotech. 2: 51-62.

Chanley P, Andrews JD (1971). Aids for the identification of bivalve larvae of Virginia. Malacol. 11: 45-119.

Coffroth MA, Mulawka JM III (1995). Identification of marine invertebrate larvae by means of PCR-RAPD species-specific markers. Limnol. Oceanogr. 40: 181-189.

Costas E, Lopez-Rodas V (1996). Enumeration and separation of the toxic dinoflagellate Alexandrium minutum from natural samples using immunological procedures with blocking antibodies. J. Exp. Mar. Biol. Ecol. 198: 81-87.

Culverhouse PF, Dimpson RG, Ellis R, Lindley JA, Williams R, Parisini T, Reguera B, Bravo I, Zoppoli R, Earnshaw G, McCall H, Smith G (1996). Automatic classification of field-collected dinoflagellates by artificial neural network. Mar. Ecol. Prog. Ser. 139: 281-287.

Dahle AB, Laake M (1982). Diversity dynamics of marine bacteria studied by immunofluorescent staining on membrane filters. Appl. Environ. Microbiol. 43: 169176.

Davis CS, Gallager SM, Berman MS, Haury LR, Strickler JR (1992a). The Video Plankton Recorder (VPR): design and initial results. Arch. Hydrobiol. Beih. 36: 67-81.

Dawson MN, Raskoff KA, Jacobs DK (1998). Field preservation of marine invertebrate tissue for DNA analyses. Molec. Mar. Biol. Biotechnol. 7: 145-152.

DeLong EF, Franks DG, Alldredge AL (1993). Phylogenetic diversity of aggregateattached vs. free-living marine bacterial assemblages. Limnol. Oceanogr. 38: 924- 934. 
DeLong EF, Wickham GS, Pace NR (1989). Phylogenetic stains: Ribosomal RNAbased probes for the identification of single cells. Science 243: 1360-1363.

Demers A, Lagadeuc Y, Dodson JJ, Lemieux R (1993). Immunofluorescence identification of early life history stages of scallops (Pectinidae). Mar. Ecol. Progr. Ser. 97: 83-89.

Dickey TD (1988). Recent advances and future directions in multi-disciplinary in situ oceanographic measurement systems. In: Rothschild BJ (ed.), Toward a Theory on Biological-Physical Interactions in the World Ocean. Kluwer Academic Publishers, Boston, MA, pp. 555-598.

Estep KW, MacIntyre F (1989). Counting, sizing, and identification of algae using image analysis. Sarsia 74: 261-268.

Fawell JK (1976). Electronic measuring devices in the sorting of marine zooplankton. In: Steedman HF (ed.), Zooplankton Fixation and Preservation. UNESCO, Paris, pp. 201-206.

Feller RJ, Gallagher ED (1982). Antigenic similarities among estuarine soft-bottom benthic taxa. Oecologia 52: 305-310.

Feller RJ, Taghon GL, Gallagher ED, Kenny GE, Jumars PA (1979). Immunological methods for food web analysis in a soft-bottom benthic community. Mar. Biol. 54: 6174.

Folmer O, Black M, Hoeh W, Lutz RA, Vrijenhoek R (1994). DNA primers for amplification of mitochondrial cytochrome c oxidase subunit I from diverse metazoan invertebrates. Mol. Mar. Biol. Biotechnol. 3: 294-299.

France SC, Kocher TD (1996). DNA sequencing of formalin-fixed crustaceans from archival research collections. Molec. Mar. Biol. Biotechnol. 5: 304-313.

Frese AM, Hare M, Palumbi SR, Butman CA (submitted). Rapid divergence of bivalve mitochondrial COI: The implications for molecular evolution and species identification. (for Mar. Biol.)

Fuller SC, Lutz RA, Pooley A (1989). Procedures for accurate documentation of shapes and dimensions of larval bivalve shells with Scanning Electron Microscopy. Trans. Am. Microsc. Soc. 108: 58-63.

Gaffney PM, Allen SK (1993). Hybridization among Crassostrea species: A review. Aquaculture. 116: 1-13. 
Gallager SM, Davis CS, Epstein AW, Solow A (1996). High-resolution observations of plankton spatial distributions correlated with hydrography in the Great South Channel, Georges Bank. Deep-Sea Res, Pt. II. 43: 1627-1663.

Garland ED, Butman CA (1996). Measuring diversity of planktonic larvae. Oceanus 39: 12 .

Geller JB (1996). Molecular approaches to the study of marine biological invasions. In: Ferraris JD, Palumbi SR (eds.), Molecular Zoology: Advances, Strategies, and Protocols. John Wiley and Sons, Inc, NY, pp. 119-132.

Geller JB, Carlton JT, Powers DA (1993). Interspecific and intrapopulation variation in mitochondrial ribosomal DNA sequences of Mytilus spp. (Bivalvia: Mollusca). Mol. Mar. Biol. Biotechnol. 2: 44-50.

Gevirtz JL (1976). Fourier analysis of bivalve outlines: Implications on evolution and autecology. Math. Geol. 8: 151-163.

Giovannoni SJ (1991). The polymerase chain reaction. In: Stackebrandt E, Goodfellow M (eds.), Nucleic Acid Techniques in Bacterial Systematics. John Wiley and Sons, NY, pp. 175-201.

Gosner KL (1979). Guide to Identification of Marine and Estuarine Invertebrates. Cape Hatteras to Bay of Fundy. Wiley-Interscience, NY.

Greene CH, Wiebe PH (1990). Bioacoustical oceanography: New tools for zooplankton and micronekton research in the 1990's. Oceanography 3: 12-17.

Grosberg RK (1982). Intertidal zonation of barnacles: the influence of planktonic zonation of larvae on vertical distribution of adults. Ecol. 63: 894-899.

Hanna PJ, Richardson BJ, Altmann K, Smith JM, Roper KG, Hammond L (1994). The production of monoclonal antibodies for use as probes in the identification of Northern Australian Crown-of-Thorns Starfish and commercial prawn larvae. In: Sammarco PW, Heron ML (eds.), The Bio-Physics of Marine Larval Dispersal. Coastal and Estuarine Studies. American Geophysical Union, Washington, DC, pp. 215-229.

Hannan CA (1981). Polychaete larval settlement: Correspondence of patterns in suspended jar collectors and in the adjacent natural habitat in Monterey Bay, California. Limnol. Oceanogr. 26: 159-171.

Hare MP, Palumbi SR, Butman CA (In prep). Single-step species identification of bivalve larvae using multiplex PCR (for Mar. Biol.). 
Harlow E, Lane D (1988). Antibodies, A Laboratory Manual. Cold Spring Harbor Laboratory Publications, NY.

Herman AW (1992). Design and calibration of a new optical plankton counter capable of sizing small zooplankton. Deep-Sea Res. 39(A): 395-415.

Hockfield S, Carlson S, Evans C, Levitt P, Pintar J, Silberstein L (1993). Selected Methods for Antibody and Nucleic Acid Probes. Molecular Probes of the Nervous System, Volume 1. Cold Spring Harbor Laboratory Press, NY.

Holliday DV (1980). Use of frequency diversity for marine biological measurements. In: Diemer FP (eds.), Advanced Concepts in Ocean Measurements for Marine Biology. University of South Carolina Press, Columbia, SC, pp. 423-460.

Hu YP, Lutz RA, Vrijenhoek RC (1992). Electrophoretic identification and genetic analysis of bivalve larvae. Mar. Biol. 113: 227-230.

Inoué S (1986). Video Microscopy. Plenum, NY.

Jeffreys AJ, Wilson V, Thein SL (1985). Individual-specific "fingerprints" of human DNA. Nature 316: 76-79.

Jeffries HP, Berman MS, Poularikas AD, Katsinis C, Melas I, Sherman K, Bivins L (1984). Automated sizing, counting and identification of zooplankton by pattern recognition. Mar. Biol. 78: 329-334.

Jørgensen CB (1946). Lamellibranchia. In: Thorson G., Reproduction and larval development of Danish marine bottom invertebrates with special reference to the planktonic larvae in the Sound (Øresund). Medd. Komm. Danm. Fiskeri-og Havunders Ser. Plankton 4: 1-523.

Kenchington EL, Roddick DL, Singh RK, Bird CJ (1994). Analysis of small-subunit rRNA gene sequences from six families of mollusks. J. Mar. Biol. Biotechnol. 1: 215217.

Lebour MV (1938). Notes on the breeding of some lamellibranchs from Plymouth and their larvae. J. Mar. Biol. Assoc. U.K. 23: 119-144.

Le Pennec M (1980). The larval and post-larval hinge of some families of bivalve molluscs. J. Mar. Biol. Assoc. U.K. 60: 601-617.

Levin LA (1990). A review of methods for labeling and tracking marine invertebrate larvae. Ophelia 32: 115-144. 
Loosanoff VL, Davis HC, Chanley PE (1966). Dimensions and shapes of larvae of some marine bivalve mollusks. Malacologia 4: 351-435.

Lutz R, Goodsell J, Castagna M, Chapman S, Newell C, Hidu H, Mann R, Jablonski D, Kennedy V, Siddall S, Goldberg R, Beattie H, Falmagne C, Chestnut A, Partridge A (1982). Preliminary observations on the usefulness of hinge structures for identification of bivalve larvae. J. Shell. Res. 2: 65-70.

Lutz RA, Hidu H (1979). Hinge morphogenesis in the shells of larval and early postlarval mussels (Mytilus edulis L. and Modiolus modiolus [L.]). J. Mar. Biol. Assoc. UK. 59: 111-121.

Lutz RA, Jablonski D (1978a). Classification of bivalve larvae and early postlarvae using scanning electron microscopy. Am. Zool. 18: 647.

Lutz RA, Jablonski D (1979). Micro- and ultramorphology of larval bivalve shells: Ecological, paleoecological, and paleoclimatic applications. Proc. Natl. Shellfish Assoc. 69: 197-198.

Ma H, Grassle JP, Butman CA (1999). Mesoscale spatial distribution of surf clam larvae at LEO-15 on the New Jersey continental shelf. Amer. Soc. Limnol. Oceanogr., Meeting Feb. 1-5, 1999, Santa Fe, NM (Abstract).

Macario AJL, Conway de Macario E (1983). Antigenic fingerprinting of methanogenic bacteria with polyclonal antibody probes. System. Appl. Microbiol. 4: 451-458.

Macario EHM (1982). Identification y clasificacion inmunquimica de bivalvos (Almejas), Instituto Tecnologico de la Paz: 34.

Mann R (1988). Field studies of bivalve larvae and their recruitment to the benthos: A commentary. J. Shell. Res. 7: 7-10.

Martin AP, Humphreys R, Palumbi SR (1992). Population genetic structure of the armorhead, Pseudopentaceros wheeleri, in the North Pacific Ocean: Application of the polymerase chain reaction to fisheries problems. Can. J. Fish. Aquat. Sci. 49: 23862391.

McCall H, Bravo I, Lindley JA, Reguera B (1996). Phytoplankton recognition using parametric discriminants. J. Plankton Res. 18: 393-410.

McDonald JH, Seed R, Koehn RK (1991). Allozymes and morphometric characters of three species of Mytilus in the Northern and Southern hemispheres. Mar. Biol. 111:323333. 
Mederios-Bergen DE, Olson RR, Conroy JA, Kocher TD (1995). Distribution of holothurian larvae determined with species-specific genetic probes. Limnol. Oceanogr. 40: $1225-1235$.

Mendoza H, Lopez-Rodas V, Gonzalez-Gil S, Aguilera A, Costas E (1995). The use of polyclonal antisera and blocking of antibodies in the identification of marine dinoflagellates: Species-specific and clone-specific antisera against Gymnodinium and Alexandrium. J. Exp. Mar. Biol. Ecol. 186: 103-115. .

Miller KM, Jones P, Roughgarden J (1991). Monoclonal antibodies as species-specific probes in oceanographic research: examples with intertidal barnacle larvae. Mol. Mar. Biol. Biotech. 1: 35-47.

Miyazaki I (1962). On the identification of lamellibranch larvae. Bull. Jap. Soc. Sci. Fish. 28: 955-966.

Naylor RL, Lubchenco J, Primavera J, WIlliams M (1998). Nature's subsidies to shrimp and salmon farming. Science. 282: 883-884.

Nadeau L, Paige JA, Starczak V, Capo T, Lafler J, Bidwell JP (1989). Metamorphic competence in Aplysia californica Cooper. J. Exp. Mar. Biol. Ecol. 131: 171-193.

Ó Foighil D, Gaffney PM, Hilbish TJ (1995). Differences in mitochondrial 16S ribosomal gene sequences allow discrimination among American (Crassostrea virginica (Gmelin)] and Asian [C. gigas (Thunberg) C. ariakensis (Wakiya)] oyster species. J. Exp. Mar. Biol. Ecol. 192: 211-220.

Ó Foighil D, Gaffney PM, Wilbur AE, Hilbish TJ (1998). Mitochondrial cytochrome oxidase I gene sequences support an Asian origin for the Portuguese oyster Crassostrea angulata. Mar. Biol. 131: 497-503.

Ohman MD, Theilacker GH, Kaupp SE (1991). Immunochemical detection of predation on ciliate protists by larvae of the Northern Anchovy (Engraulis mordax). Biol. Bull. 181: $500-504$.

Olson RR, Rustadler JA, Kocher TD (1991). Whose larvae? Nature 351: 357-358.

Ortner PB, Hill LC, Edgerton HE (1981). In situ silhouette photography of Gulf Stream zooplankton. Deep-Sea Res. 28A: 1567-1576.

Palumbi SR, Benzie J (1991). Large mitochondrial DNA differences between morphologically similar Penaeid shrimp. Mol. Mar. Biol. Biotech. 1: 27-34. 
Pech-Pacheco JL, Alvarez-Borrego J (1988). Optical-digital system applied to the identification of five phytoplankton species. Mar. Biol. 132: 357-365.

Pieper RE, Holliday DV (1984). Acoustical measurements of zooplankton distributions in the sea. J. Cons. Int. Explor. Mer. 41: 226-238.

Powers DA, Allendorf FW, Chen T (1990). Application of molecular techniques to the study of marine recruitment problems. In: Sherman K, Alexander LM, Gold BD (eds.), Large Marine Ecosystems. Patterns, Processes and Yields. American Association for the Advancement of Science, Washington, DC, pp. 104-121.

Powers DA, Chen TT, DiMichele L, Chapman RW, Gonzalez-Villasenor LI (1988). A molecular approach to recruitment problems: genetics and physiology. In: Rothschild BJ (ed.), Toward a Theory on Biological-Physical Interactions in the World Oceans. Kluwer Academic Publishers, Boston, MA, pp. 411-440.

Recktenwald D (1992). Multicolor immunofluorescence analysis. In: Radbruch A (ed.), Flow Cytometry and Cell Sorting. Springer-Verlag, NY, pp. 47-52.

Rees CB (1950). The identification and classification of lamellibranch larvae. Hull Bull. Mar. Ecol. 3: 73-104.

Rice EL (1990). Nucleotide sequence of the 18S ribosomal RNA gene from the Atlantic sea scallop Placopecten magellanicus (Gmelin, 1791). Nucleic Acids Res. 18: 5551.

Rice EL, Roddick D, Singh RK (1993). A comparison of molluscan (Bivalvia) phylogenies based on palaeontological and molecular data. Mol. Mar. Biol. Biotechnol. 2: $137-146$.

Scheltema RS (1986). On dispersal and planktonic larvae of benthic invertebrates: An eclectic overview and summary of problems. Bull. Mar. Sci. 39: 290-322.

Shanks AL, Wright WG (1987). Internal-wave-mediated shoreward transport of cyprids, megalopae, and gammarids and correlated longshore differences in the settling rate of intertidal barnacles. J. Exp. Mar. Biol. Ecol. 114: 1-13.

Shapiro LP, Campbell L, Haugen EM (1989). Immunochemical recognition of phytoplankton species. Mar. Ecol. Prog. Ser. 57: 219-224.

Shirley SM, Shirley TC, Rice SD (1987). Latitudinal variation in Dungeness crab, Cancer magister: Zoeal morphology explained by incubation temperature. Mar. Biol. 95: 371-376. 
Sieracki ME, Viles CL (1990). Color image-analyzed fluorescence microscopy: A new tool for marine microbial ecology. Oceanogr. 3(1): 30-36.

Silberman JD, Walsh PJ (1992). Species identification of spiny lobster phyllosome larvae via ribosomal DNA analysis. Mol. Mar. Biol. Biotech. 1: 195-205.

Stafford J (1912). On the recognition of bivalve larvae in plankton collections. Contrib. Can. Biol. 1906-1910: 221-242.

Stahl DA, Amann R (1991). Development and application of nucleic acid probes. In: Stackebrandt E, Goodfellow M (eds.), Nucleic Acid Techniques in Bacterial Systematics. John Wiley and Sons, NY, pp. 205-248.

Strathmann RR, Fenaux L, Strathmann MR (1992). Heterochronic developmental plasticity in larval sea urchins and its implications for evolution of nonfeeding larvae. Evolution. 46: 972-986.

Sullivan CM (1948). Bivalve larvae of Malpeque Bay, P.E.I. Fish. Res. Bd. Can. Bull. 77: $1-36$.

Thorson G (1946). Reproduction and larval developments of Danish marine bottom invertebrates, with special reference to the planktonic larvae in the Sound (Øresund). Medd. Komm. Danm. Fiskeri-og Havunders Ser. Plankton 4: 1-523.

Toro JE (1998). PCR-based nuclear and mtDNA markers and shell morphology as an approach to study the taxonomic status of the Chilean blue mussel, Mytilus chilensis (Bivalvia). Aquat. Living Resour. 11: 347-353.

Turner RD, Boyle PJ (1975). Studies of bivalve larvae using the scanning electron microscope and critical point drying. Am. Malac. Union, Inc. Bull. 40:59-65.

Ward BB (1990). Immunology in biological oceanography and marine ecology. Oceanogr. 3(2): 30-35.

Ward BB, Carlucci AF (1985). Marine ammonia- and nitrite-oxidizing bacteria: Seriological diversity determined by immunofluorescence in culture and in the environment. App. Environ. Microbiol. 50: 194-201.

Weinberg JR (1993). Ocean quahog populations from the Middle Atlantic to the gulf of Maine in 1992. NOAA/NMFS, Northeast Fisheries Science Center Reference Document 93-02, Woods Hole, MA, 18 pp. 
Werner B (1939). Über die Entwicklung und Artunterscheidung von Muschellarven des Nordseeplanktons, unter besonderer Berücksichtigung der Schalenentwicklung. Zool. Jahrb. Abt. Anat. Ontog. 66: 1-54.

Yentsch CM, Mague FC, Horan PK, eds. (1988). Immunochemical Approaches to Coastal, Estuarine and Oceanographic Questions. Lecture Notes on Coastal and Estuarine Studies No. 25. Springer-Verlag, NY.

Yoshida H (1953). Studies on larvae and young shells of industrial bivalves in Japan. J. Shimonoseki Coll. Fish. 3: 1-106.

Yoshida H (1957). Early life history of useful bivalves in the Ariake Sea (II). J. Shimonoseki Coll. Fish. 6: 63-68.

Zakhvatkina KA (1959). Larvae of bivalve mollusks of the Sevastopol region of the Black Sea. Akad. Nauk. SSSR, Trudy Sevastopol'skei, Biolog. Stantsii. 1: 108-152. 